\title{
آليات تحقيق الإدارة بالحب فى إدارة المدارس فى مصر ( دراسة تحليلية )
}

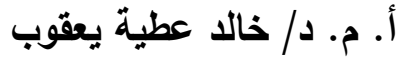 \\ أستاذ مساعد الإدارة التربوية والتربية \\ المقارنة- المعهذ العالى للدراسات النوعية \\ بالجيزة
}

هدفت الدراسة إلى تعرف الإطار الدفاهيمي للإدارة بالحب فى إدارة المدارس، والتعرض لأهم

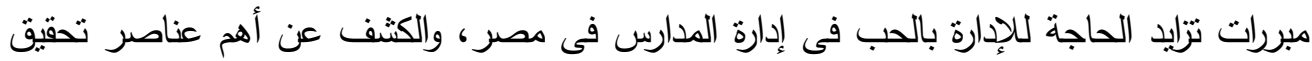

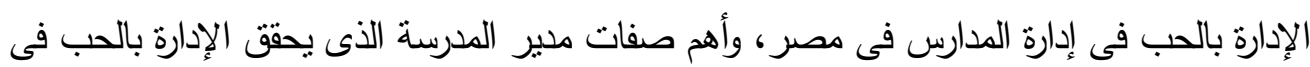

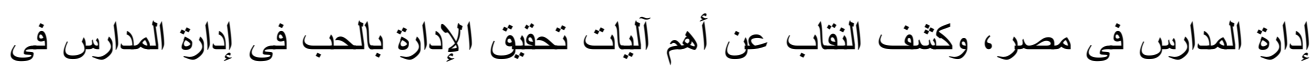

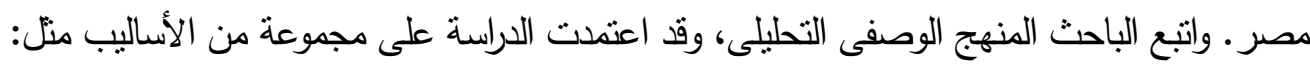
الدراسة النظرية، والزيارة الميدانية، والدراسة الاستطلاعية؛ والتى أجريت على عينة عثوائية عددها مائة وواحد مدير مدرسة فى ثلاث محافظات( البحيرة - الأسكندرية - مرسى مطروح )، وكان من أهم الهم

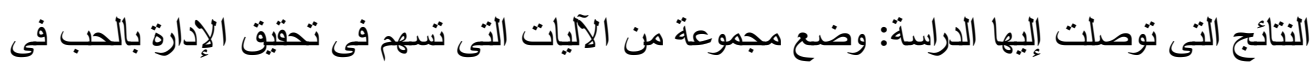

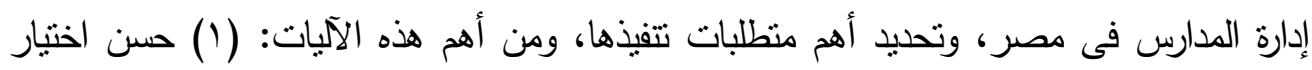

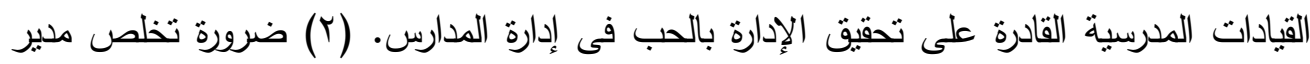

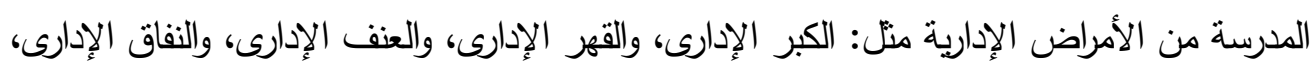

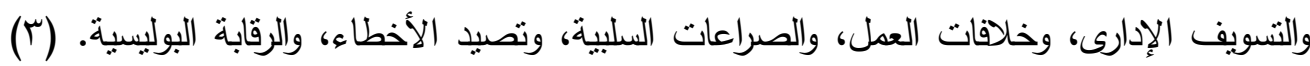

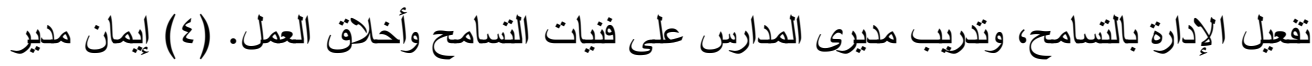

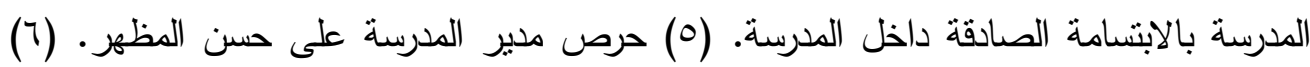

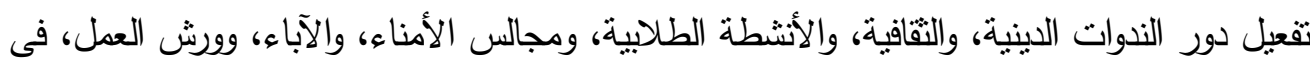

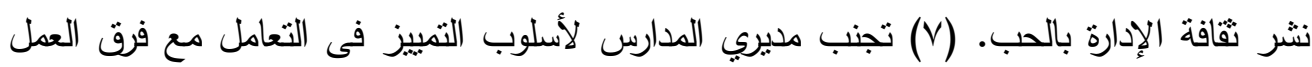

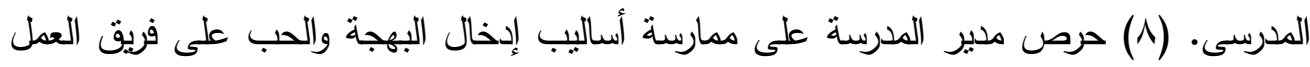
المدرسى. (9) حرص مدير الدرسة على غرس قيمة الحب فى نفوس التناميذ ، وتبصيرهم بتعظيم

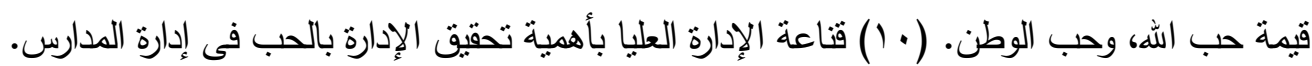

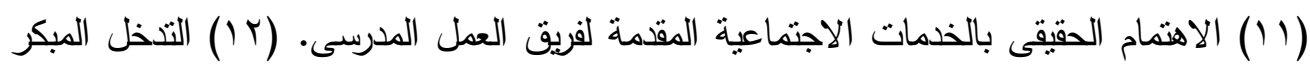

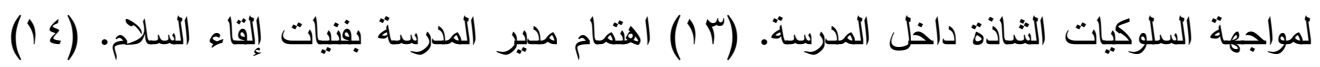
اهتمام مدير الددرسة بتجمبل مداخل وحديقة الددرسة بالورود الجميلة. 


\section{Mechanisms to Achieve Management by Love in School Administration in Egypt (Analytical Study)}

\section{Abstract :-}

The study aimed at recognizing the conceptual framework of management by love in school administration. It tackled the most important justifications for the increased need for management by love in school administration in Egypt, and the peculiarity of school principal who manages by love in his/her school. The study also unveiled the most important mechanisms to achieve management by love.

The researcher used the descriptive analytical approach, and a number of techniques such as; the theoretical study, field study, and pilot study which is conducted on a random sample of one hundred and one school principal from three governorates (El-Beheira - Alexandria - and Marsa Matruoh).

The study concludes a number of results; the most important one was setting a number of mechanisms which help in achieving management by love in school administration in Egypt and determining the most important performance requirements. The most important mechanisms were:

1) The good choice of school leaders who are able to achieve the management by love in school administration.

2) It is necessary for the school principal to give up the managerial diseases such as managerial arrogance, conquering, violence, dissemblance, temporization, work disputes, negative struggles, and police spy.

3) Activating the management by forgiveness and training the school principals on forgiveness techniques, and work morals.

4) The school principal should believe in true smile inside his school.

5) S/he should be spiffy.

6) Activating the role of religious and cultural colloquiums, students' activities, board of trustees and board of parents, workshops, in spreading the culture of management by love.

7) The school principals should avoid discrimination among members of a team work.

8) S/he should be observant of practicing the techniques of elating and blessing the school team work.

9) The school principals' observance to infix the value of love among students to enlighten them to glorify love of Allah and patriotism value.

10)The contentment of the top level managers to achieve the management by love inside school.

11)True watching over the social services presented by school teamwork.

12) The early interposition to deal with the abnormal behaviors inside school.

13)The school principal should concern in techniques of saluting.

14)Making account of adorning the school entrance and the garden with beautiful flowers and green plants. 


\section{مقدمة الاراسة :}

أنُبُ كلمة بسيطة تتكون من حرفين، إلا أنها سرٌ من أسرار نجاح المدارس على اختلاف

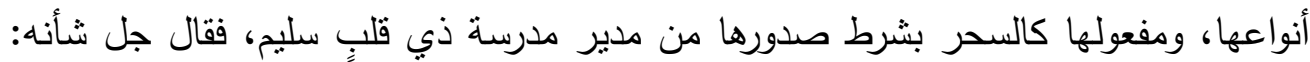

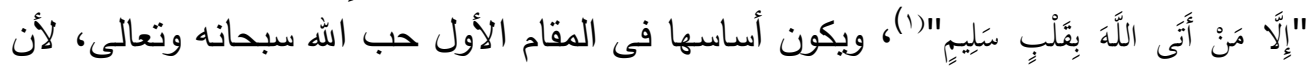

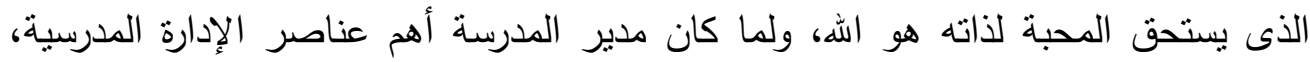

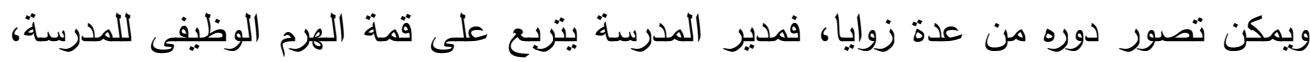

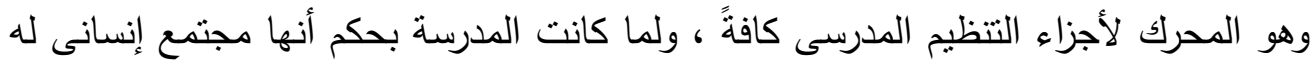

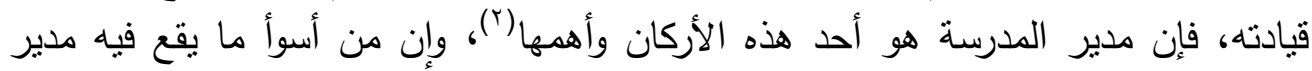

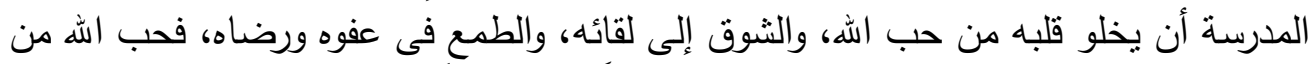

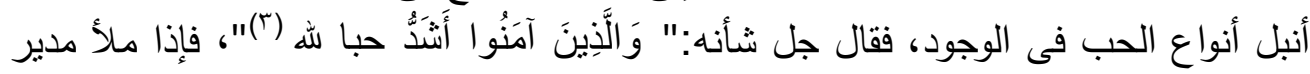

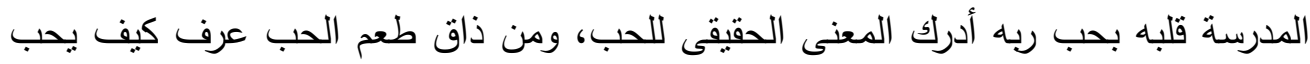

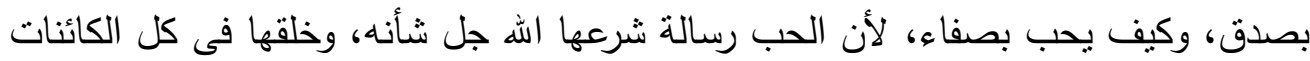

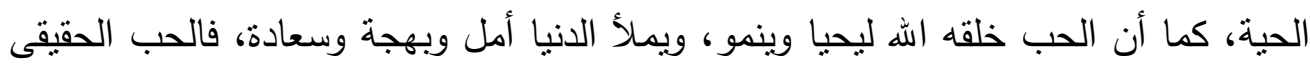

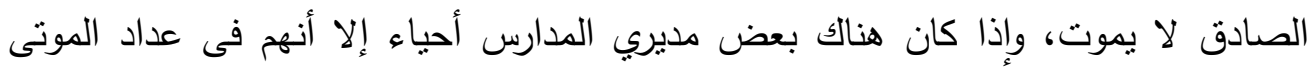

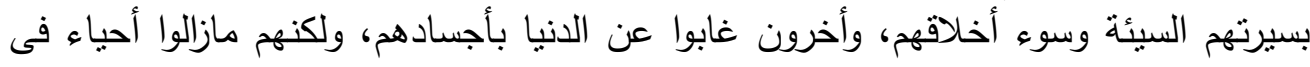

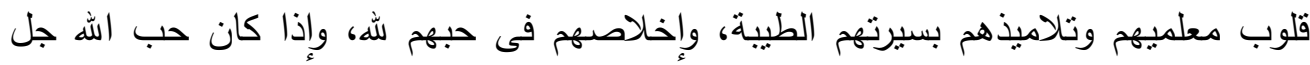

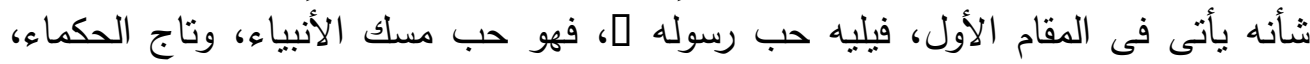

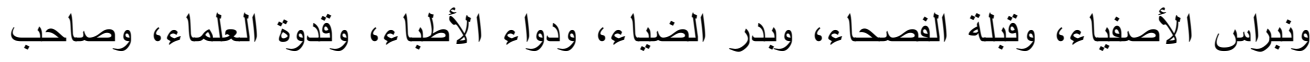

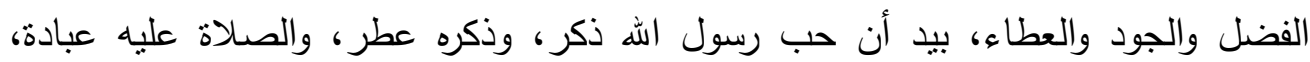

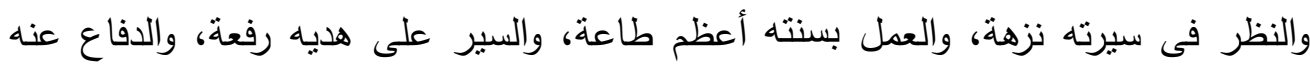

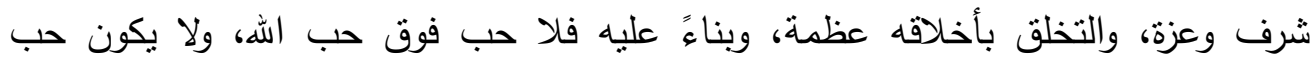

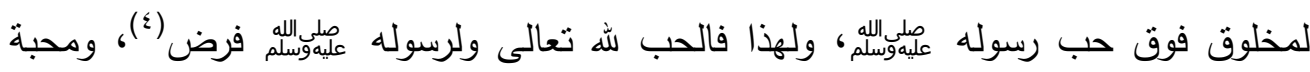

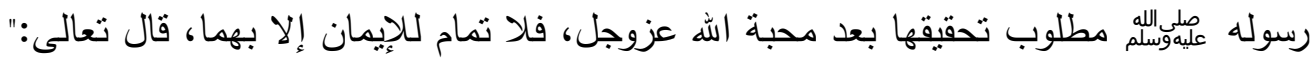

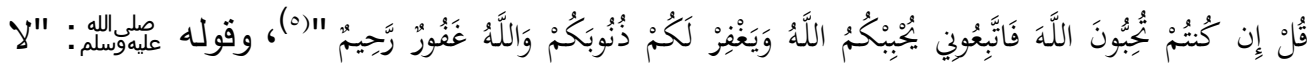

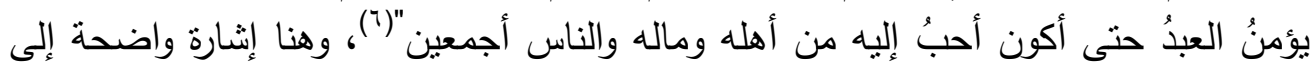

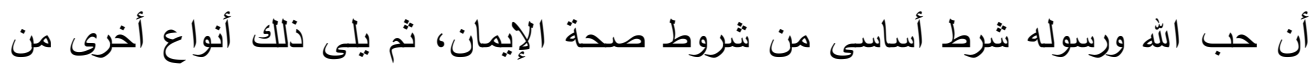

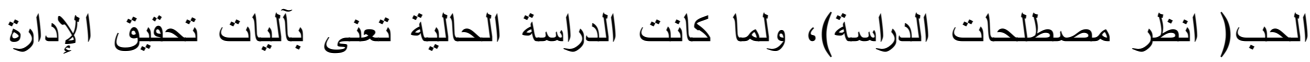

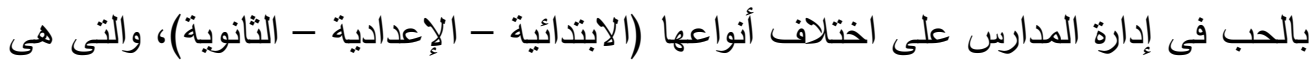

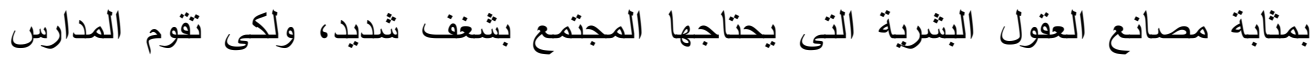

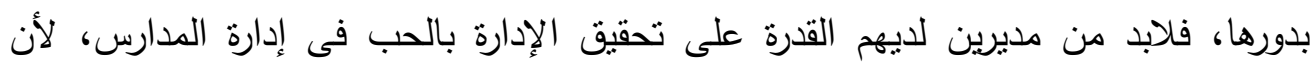

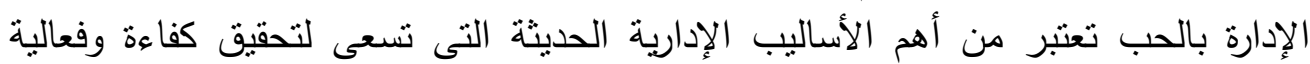

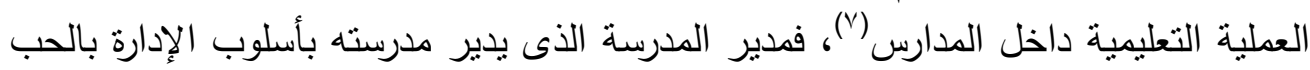




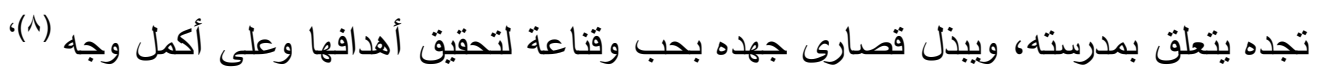

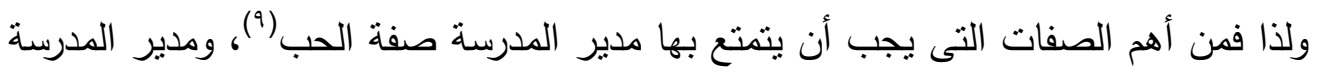

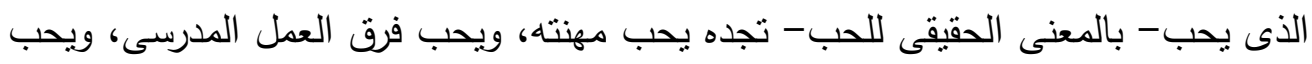

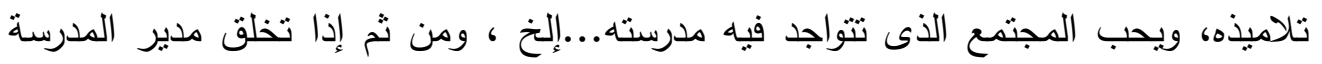

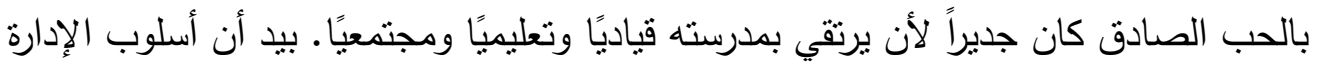

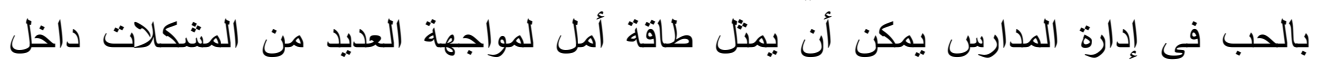

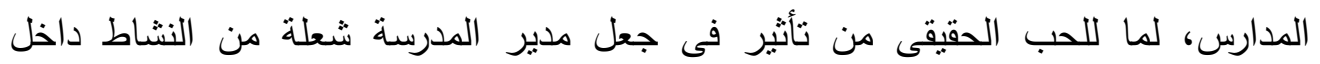

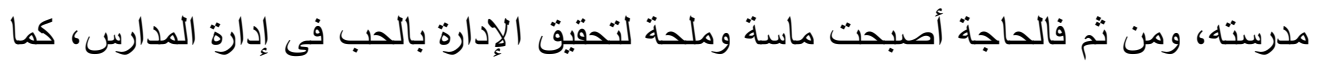

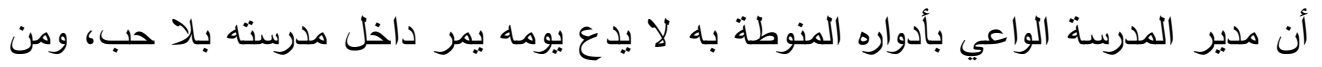

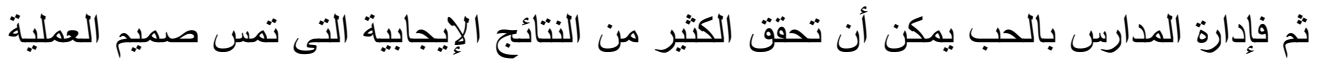

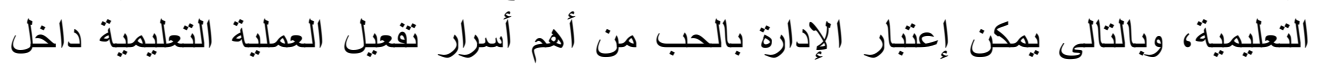

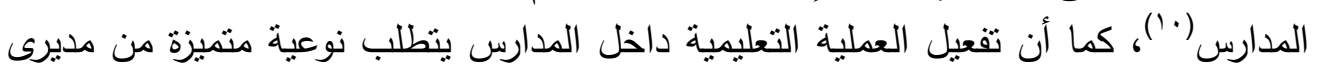

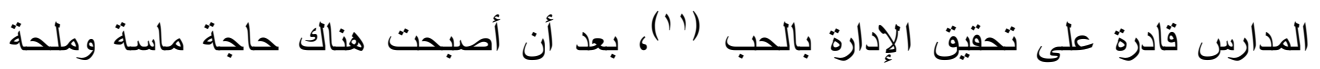

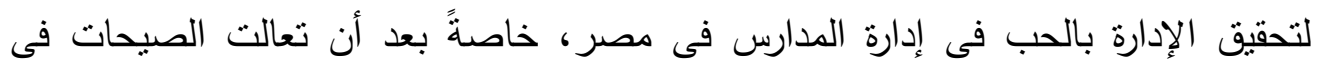

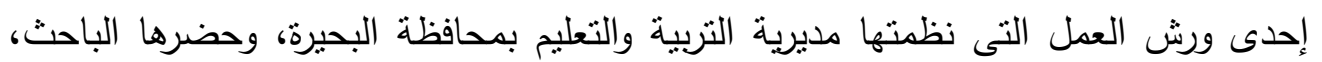

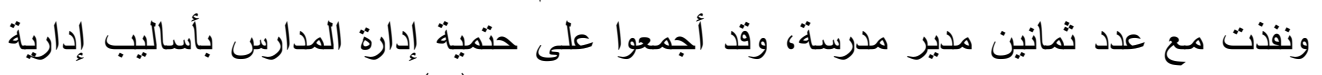

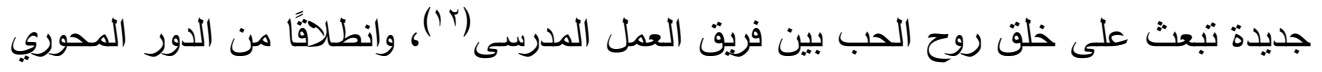

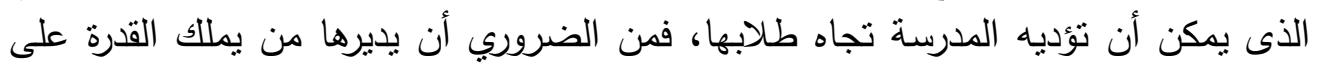

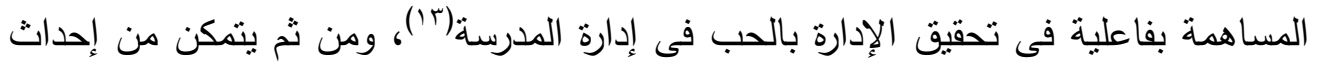

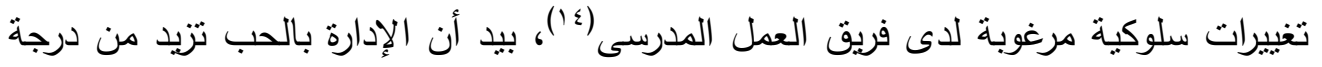

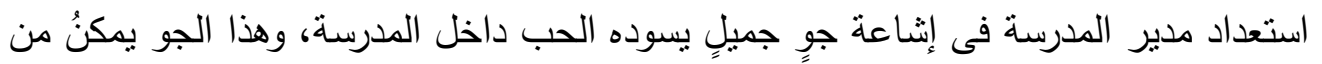

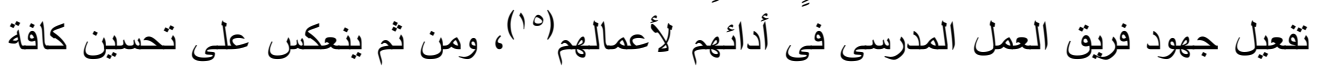

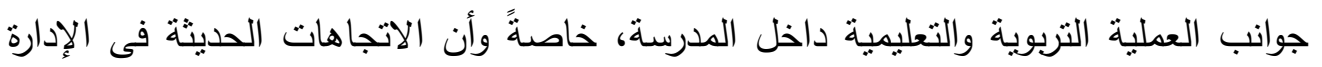

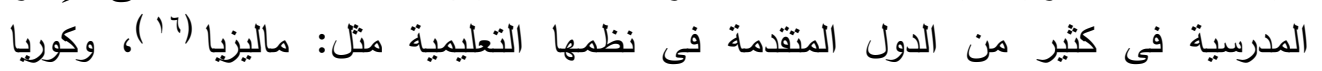

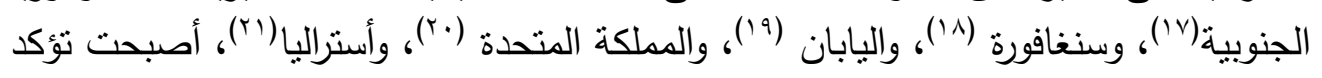

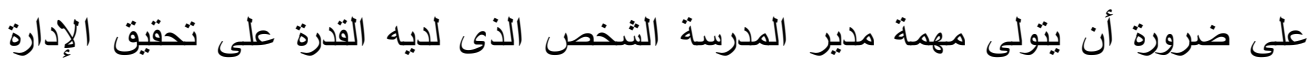

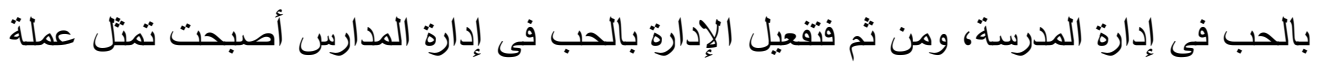

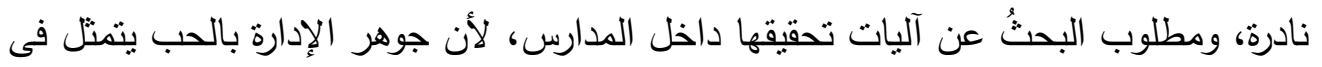

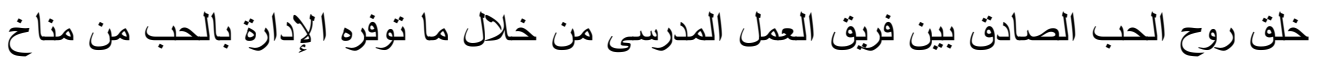

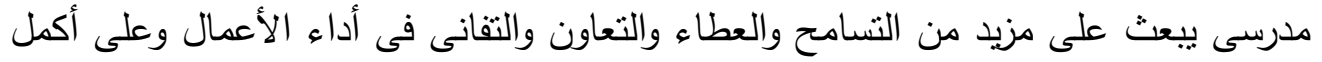

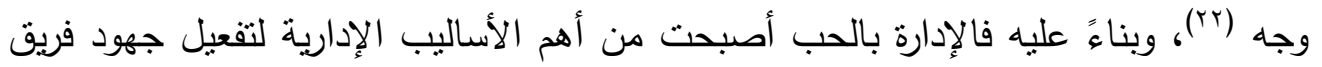
العمل المدرسى، ومن ثم تحقيق الأهداف المدرسية المنشودة. 


\section{مشكلة الدراسة:}

المدقق فى حال إدارة المدارس فى مصر يلحظ أن هناك مجموعة من الأمور الغريبة

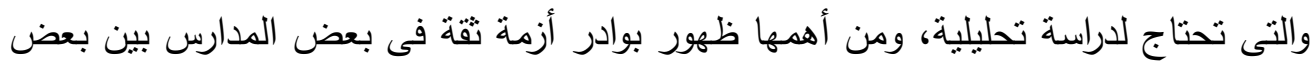

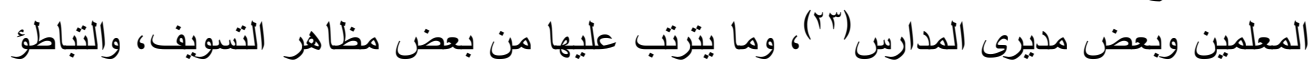

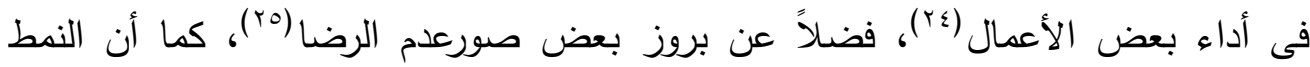

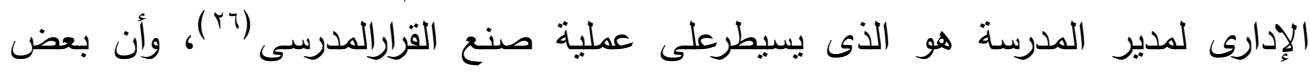

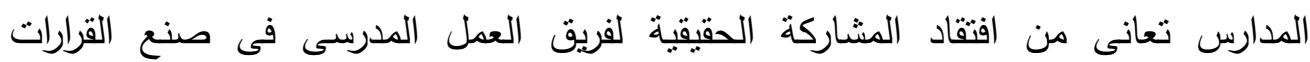

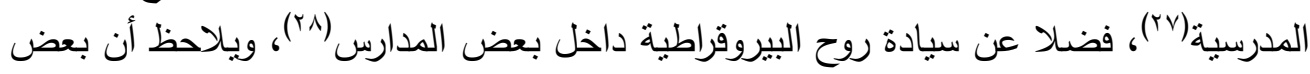

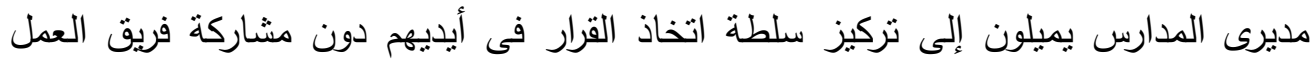

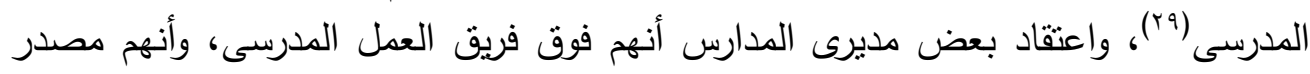

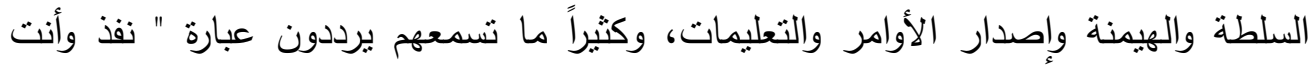

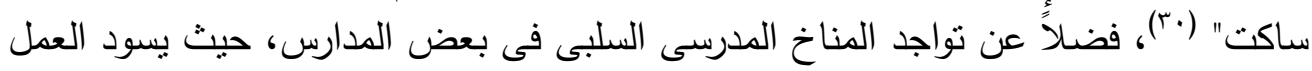

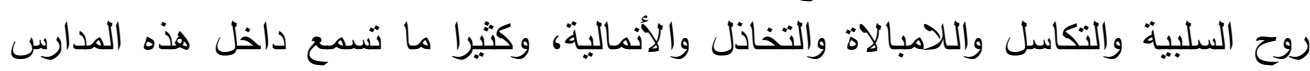

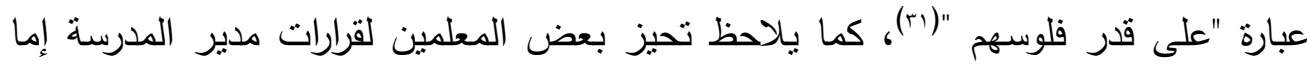

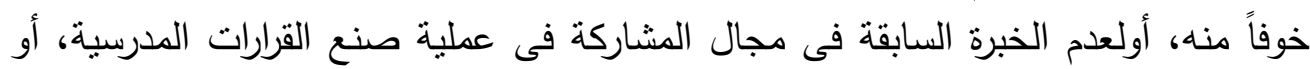

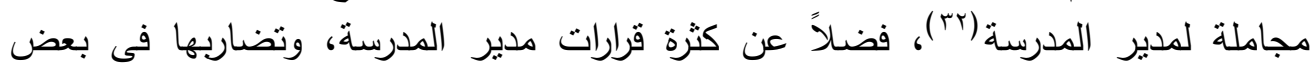

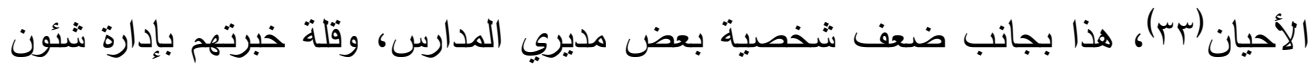

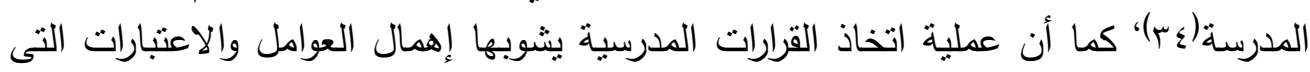

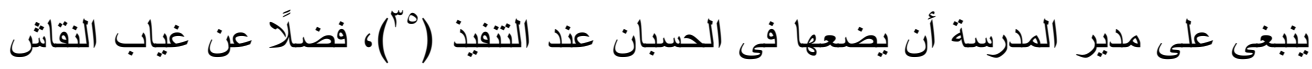

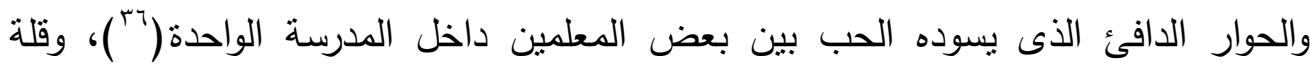

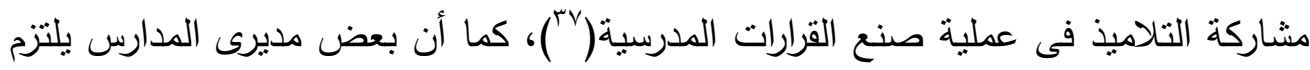

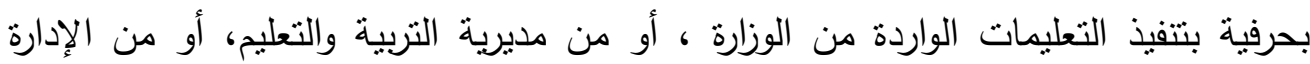

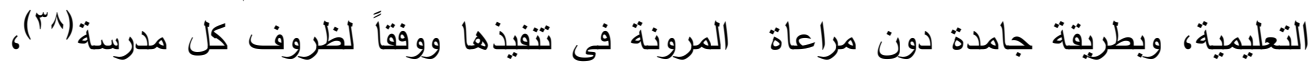

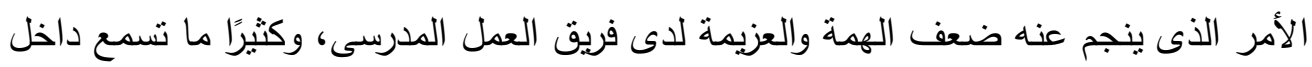

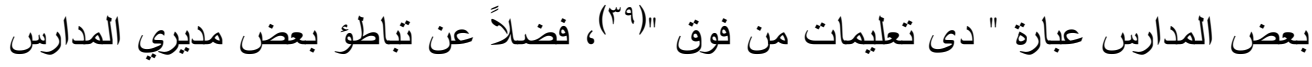

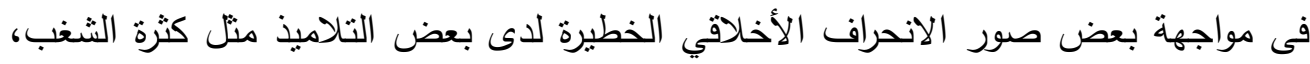

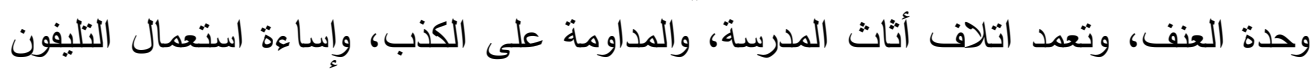

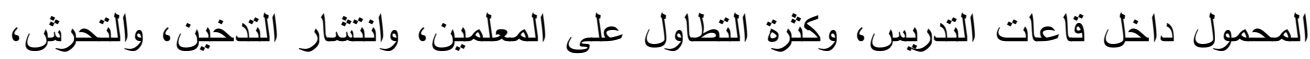

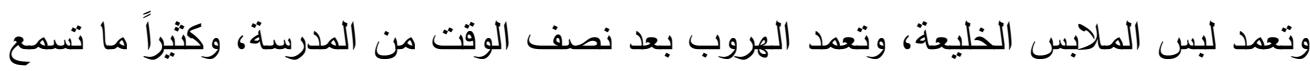

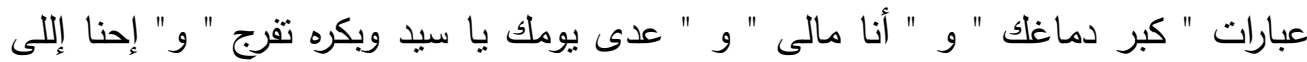

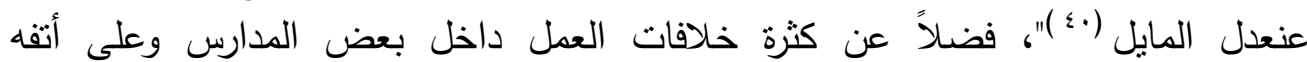


الأسباب(1)، فضلاً عن شيوع ما يسمى بالتظيمات الغير رسمية " نظام الثنلية " داخل

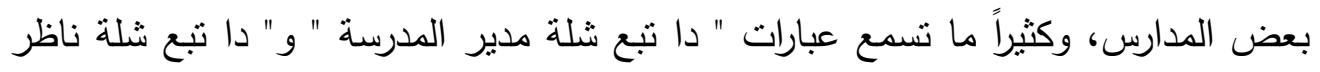

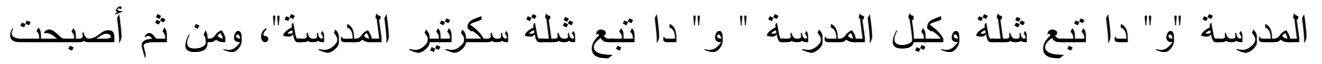

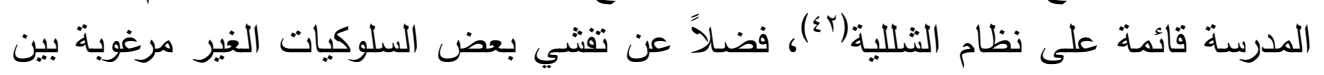

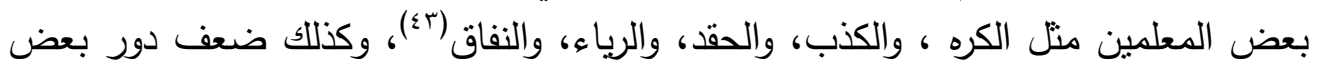

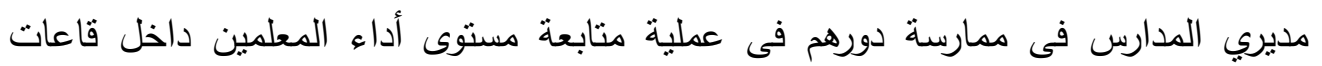
التنريس وانشغالهم بأمور تلتهم كثيراً من الوقت مثل فئل نوقيع البوستة والمراسلات وكثرة الكلام

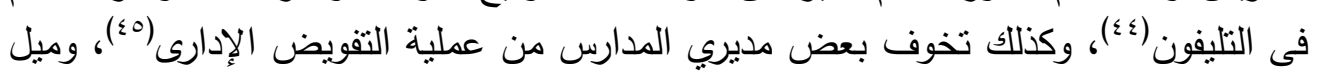

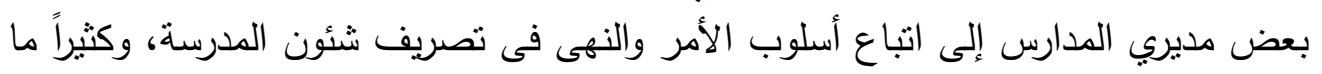

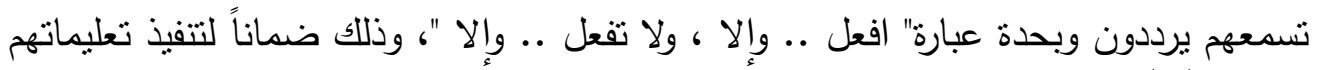

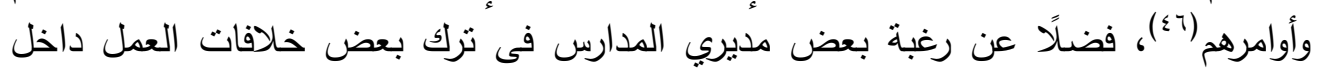

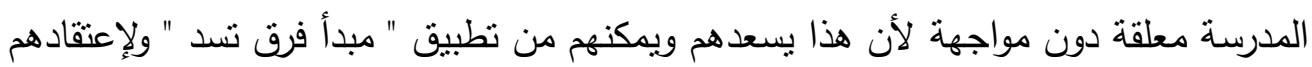

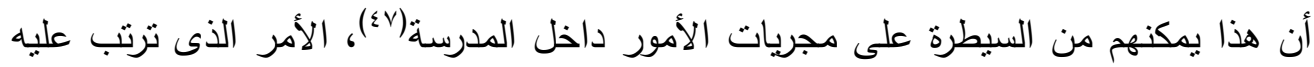

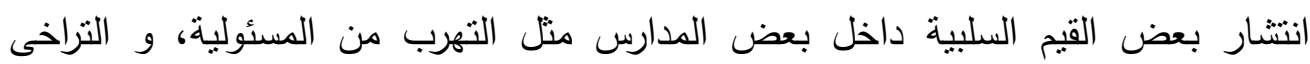

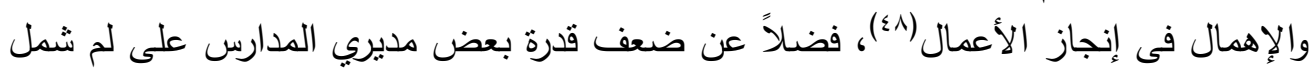

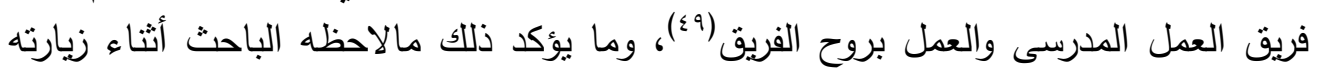

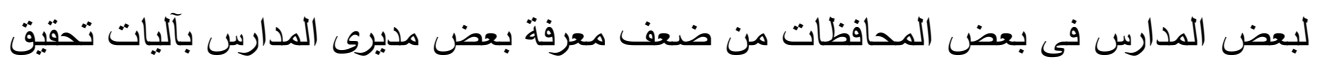

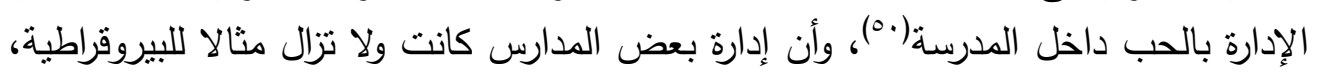

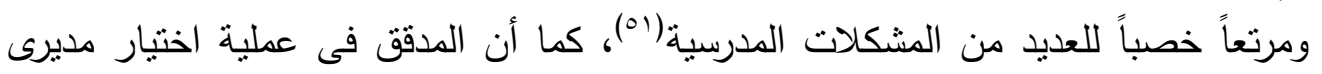

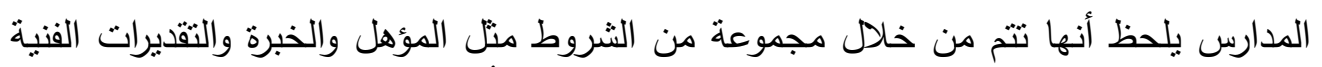

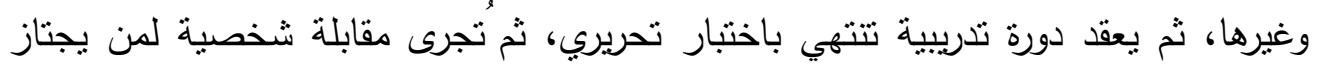

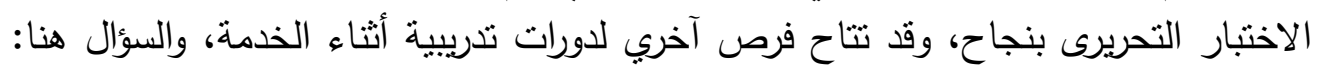

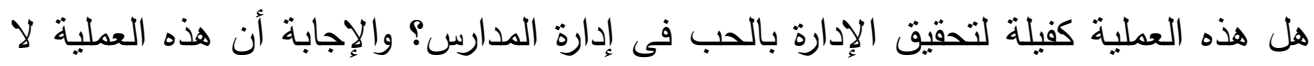

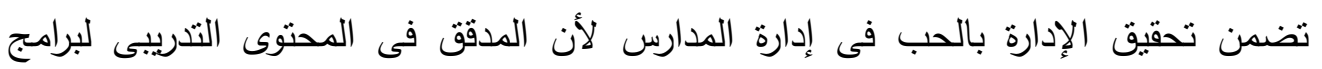

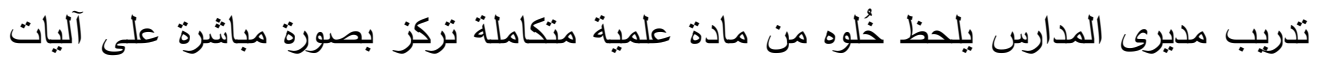

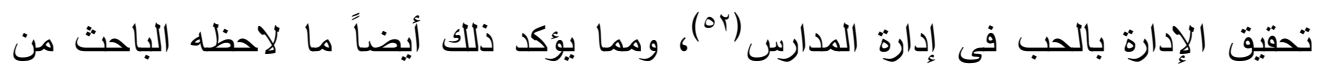

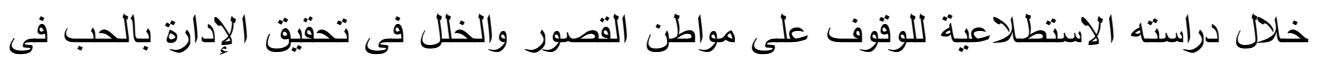

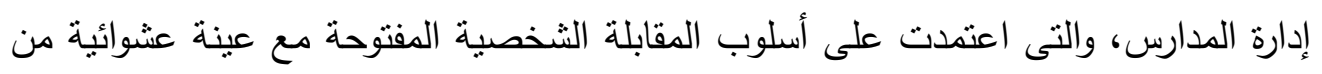

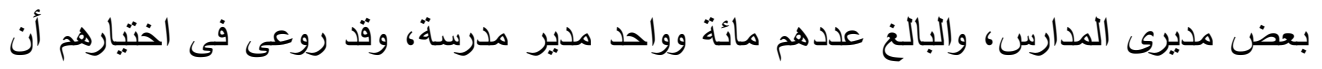

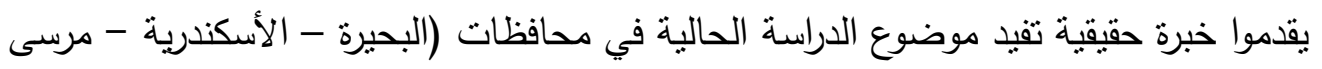

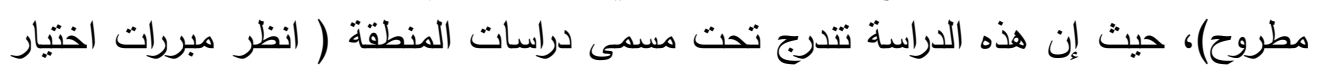

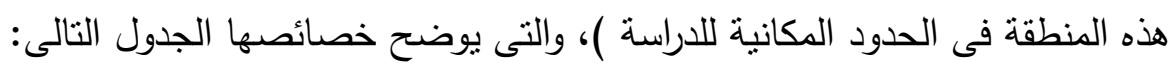


جدول (1) خصائص عينة الدراسة

\begin{tabular}{|c|c|c|c|c|c|c|c|c|c|}
\hline المجموع & فنانوى & ثنانوى & مدير ثانوى & ثانوى & $\begin{array}{l}\text { إعدادى } \\
\text { (إناث) }\end{array}$ & إعدادى مدير & ابتدائى & (ذبتدائى & المحافظة \\
\hline rq & $r$ & 7 & 0 & 7 & 0 & 0 & 0 & 0 & البحيرة \\
\hline דוץ & $r$ & $\varepsilon$ & $\varepsilon$ & 7 & 0 & 0 & 0 & 0 & الأسكندرية \\
\hline YY & 1 & $r$ & 1 & r & $\varepsilon$ & 0 & 0 & 0 & مطروحى \\
\hline 1.1 & 0 & Ir & 1. & 10 & $1 \leqslant$ & 10 & 10 & 10 & المجموع \\
\hline
\end{tabular}

وقد طرحت خلال الدراسة الاستطلاعية بعض الأسئلة، والتى يبينها الجدول التالى:

جدول (Y) يبين أسئلة المحور الأول الألئل

\begin{tabular}{|c|c|}
\hline الأسئلة & 2 \\
\hline ما معنى الحب من وجهة نظرك ؟ و هل تؤمن بالحب كقيمة ؟ ولماذا ؟ & 1 \\
\hline ما معنى: التسامح ، العطاء ، التعاون ، التقبل ؟ & r \\
\hline ولماذا ؟ هل هناك علاقة بين الحب و التسامح و العطاء و التعاون و التقبل ؟ & $\mu$ \\
\hline ما معنى الإدارة بالحب فى إدارة المدارس ؟ & $\varepsilon$ \\
\hline ت - تحقيقها فى المدارس ؟برتلك في إدارة المدر اس هل ترى أن الإدارة بالحب مطلوب & 0 \\
\hline
\end{tabular}

جدول (ץّ) يبين أسئلة المحور الثانى

\begin{tabular}{|c|c|c|}
\hline الأسئلة & & 5 \\
\hline ما أهم مؤشرات حبك لله ولرسوله عليلوسللم ؟ & - & 1 \\
\hline ما مؤشر ات حبك لنفسك ؟ & - & r \\
\hline ما مؤشر ات حبك للو الدين ( الأب ـ الأم ) ؟ & - & $r$ \\
\hline ما مؤشر ات حبك لأسر نك ( زوجتاك - أو لادك ) ؟ & - & $\varepsilon$ \\
\hline ما مؤشر ات حبك لأقاربك و الناس ؟ & - & 0 \\
\hline ما مؤشر ات حبك لوطنك ؟ & - & 7 \\
\hline
\end{tabular}

جدول (؛ ) يبين أسئلة المحور الثالث

\begin{tabular}{|c|c|c|}
\hline الأسئلة & & 5 \\
\hline ما مؤشر ات حبك للعمل القيادى ؟ & - & 1 \\
\hline ما مؤشر ات حبك للمعلمين ؟ & - & r \\
\hline ما مؤشر ات حبك للتناميذ ؟ & - & r \\
\hline ما مؤشر ات حبك للإيئة المعاونة ( الإداريين - الإخصائيين ) ؟ & - & $\varepsilon$ \\
\hline ما مؤشر ات حبك للمدرسة ؟ & - & 0 \\
\hline ما مؤشر ات حبك للإدارة التعليمية التابعة لها مدرستلك ؟ & - & 7 \\
\hline ما مؤشر ات حبك لمديرية التربية و التعليم بمحافظتلك ؟ & - & $\mathrm{V}$ \\
\hline ما مؤشر ات حبك للمجتمع و البيئة المحيطة بالمدرسة ؟ & - & $\Lambda$ \\
\hline ما أهم آليات تحقيق الإدارة بالحب فى إدارة المدارس ؟ & - & 9 \\
\hline
\end{tabular}


ومن خلال الإجابات التى حصل عليها الباحث، وردود الأفعال، والعبارات التى سمعها،

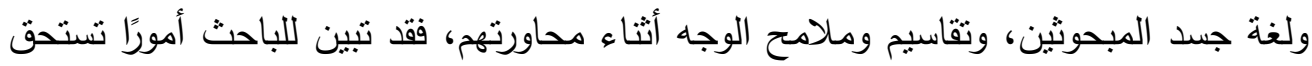

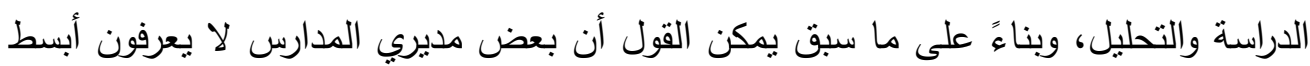

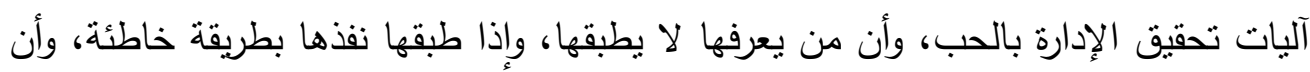
تفعيل العملية التعليمية داخل المدارس يتوقف بدرجة كبيرة على تحقيق الإدارة بالحب في إلى إدارة

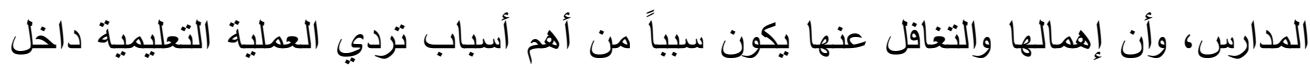

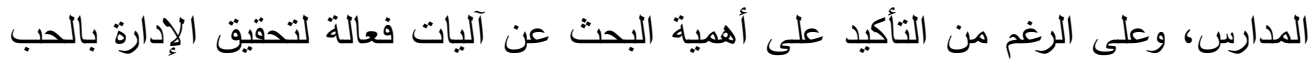

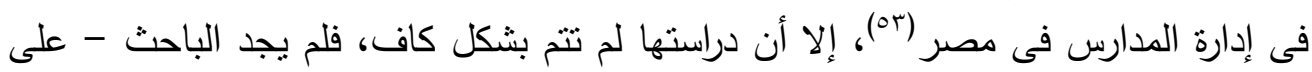

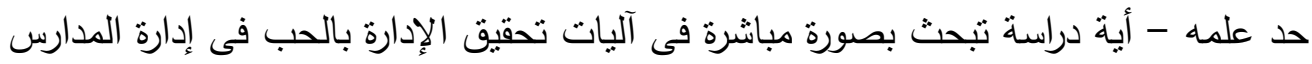

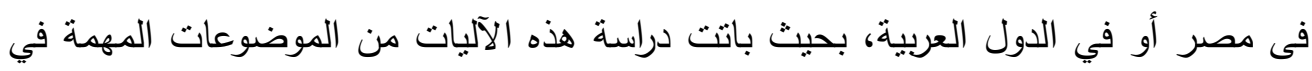

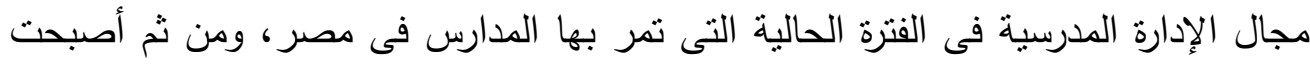

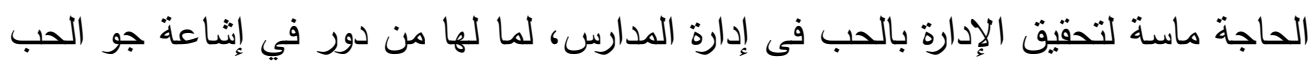

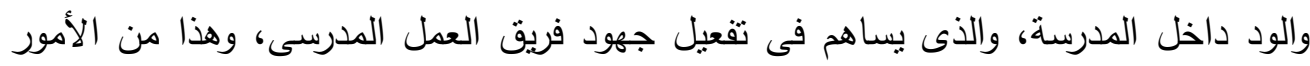

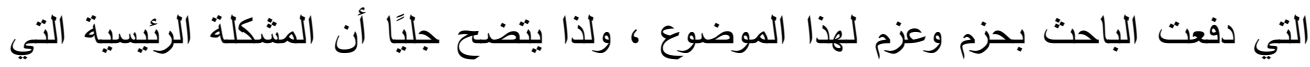

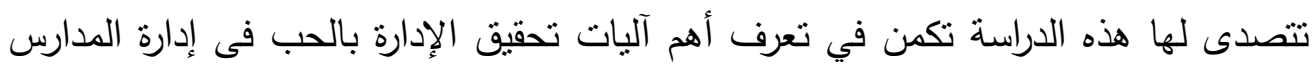

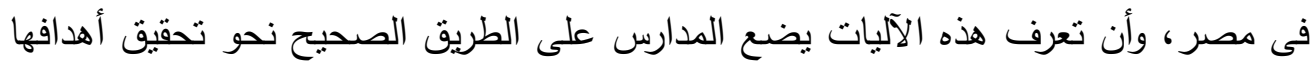

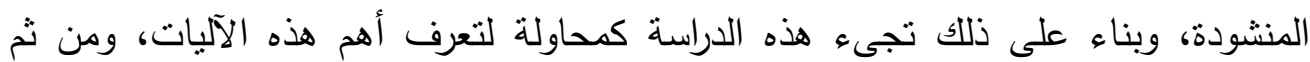

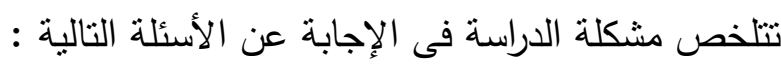

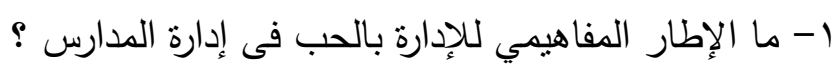

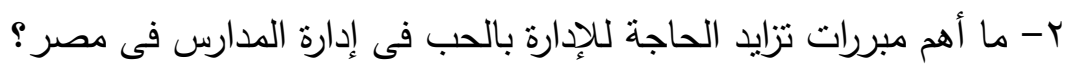

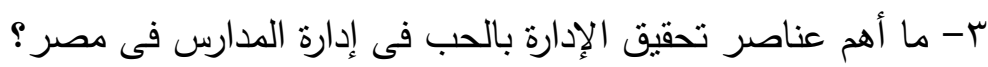

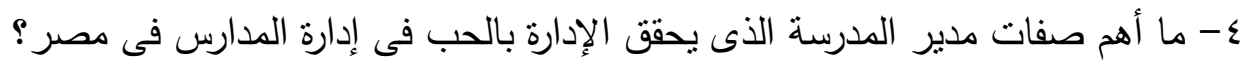

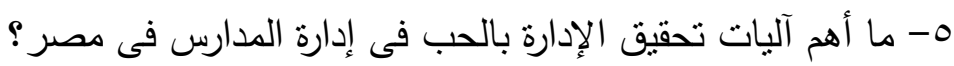

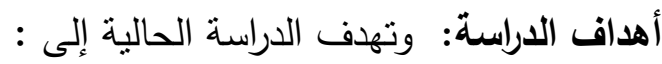

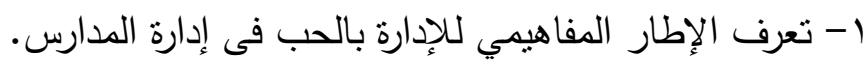

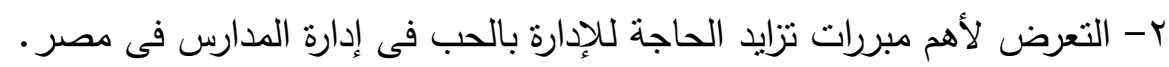

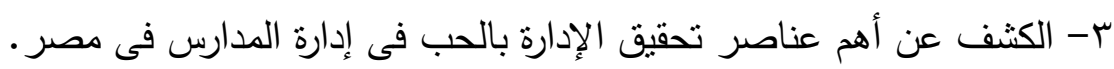

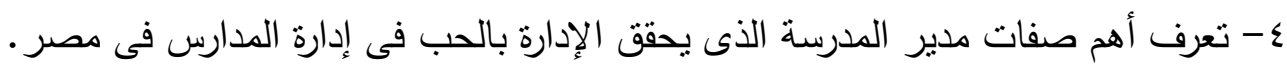

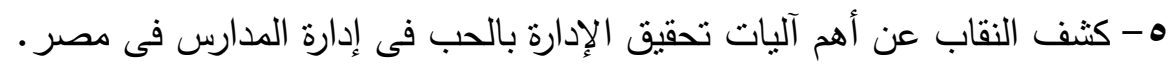




\section{أهمية الدراسة: تكتسب الدراسة الحالية أهميتها من :}

1-أنها دراسة جديدة فى موضوعها فهى تهتم بتعرف آليات تحقيق الإدارة بالحب فى إدارة المدارس فى مصر ، وما أحوج إدارة الددارس على اختلاف أنواعها لتعرف هذه الآليات،

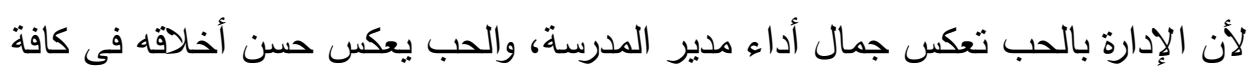
تعاملاته مع فريق العمل المدرسى، ويمثل الحب مركز كل المشاعر النبيلة لديه، وهو الذى يدفع مدير المدرسة إلى بذل قصارى جهده فى مدرسته، لأنه يمده بطاقة لتقعيل أنبل

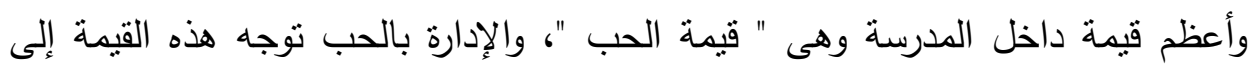
الصالح العام للمدرسة وتتغلغل فى كافة العلاقات داخل الددرسة ، ومن ثم يترتب عليها

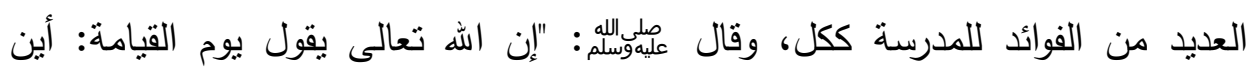

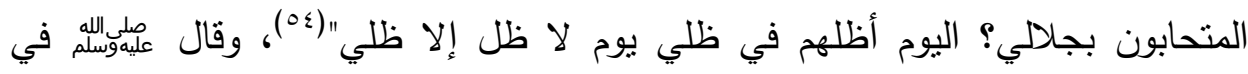
حديث السبعة الذين يظلهم الله في ظله يوم لا ظل إلا ظله "رجلان تحابا في الله اجتمعا لها لها

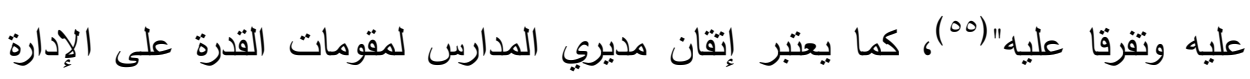

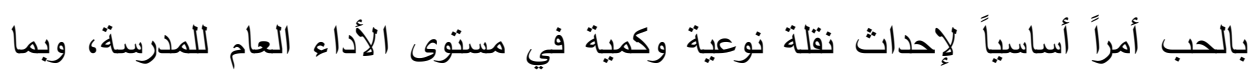
يُمكنُ من تحقيق أهدافها بكفاءة وفعالية.

ץ- أنها تضع أمام المسئولين عن تدريب مديرى المدارس أهم آليات تحقيق الإدارة بالحب وفئب فى إدارة المدارس، ومن ثم تضمين المحتوى التدريبى لمديرى المدارس بمادة تدريبية متكاملة عن هذه الآليات ومتطلبات تحقيقها.

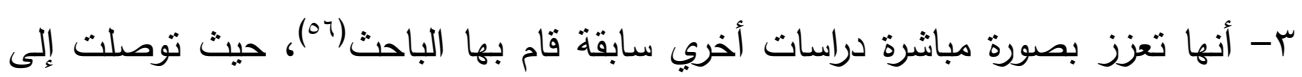

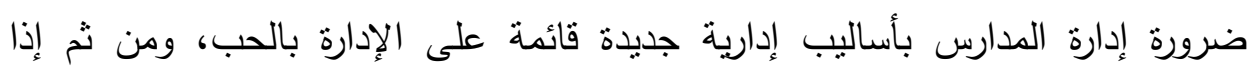
تكاملت قدرة مدير المدرسة على تحفيز المعلمين، والقيادة التيسيرية، وعلاج الوهن بالئه

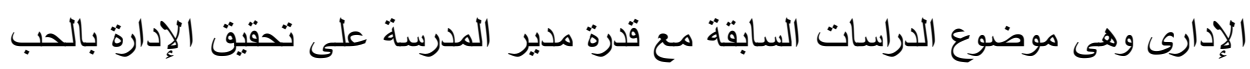

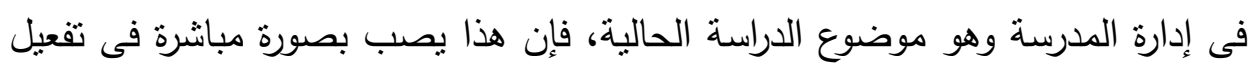

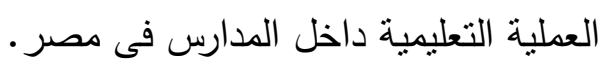
ع-تعدد الجهات والفئات المستفيدة من نتائج هذه الدراسة منل المسئولين عن اختبار مديرى هـئ

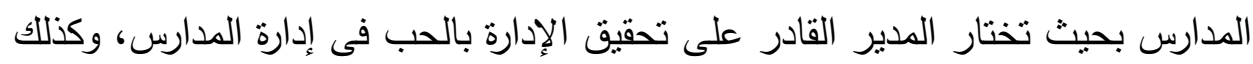
مديري ووكلاء المدارس، والمعلمين والطلاب وأولياء الأمور . 
حدود الدراسة : وتمنلت حدود هذه الدراسة فى :

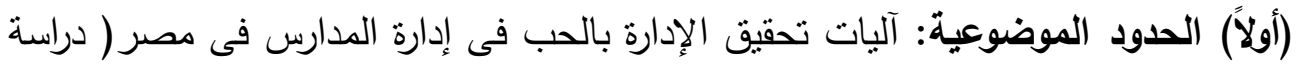

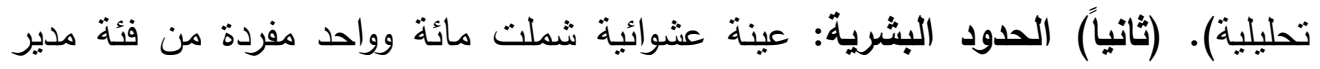

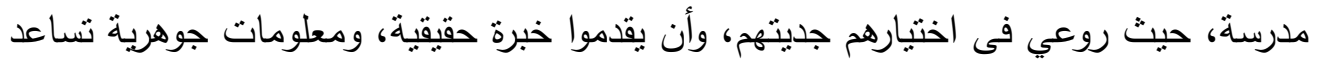

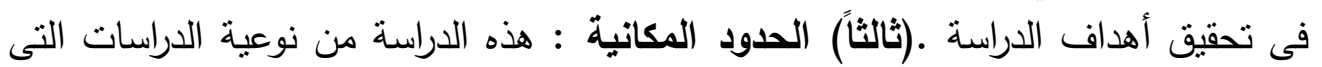

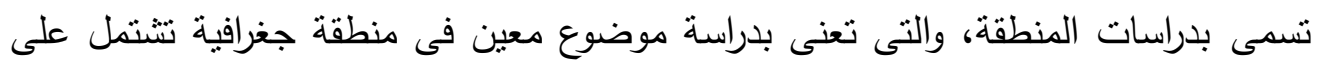

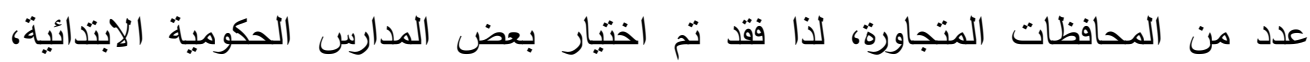

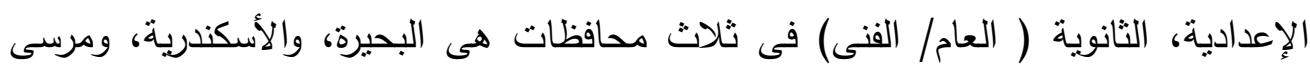

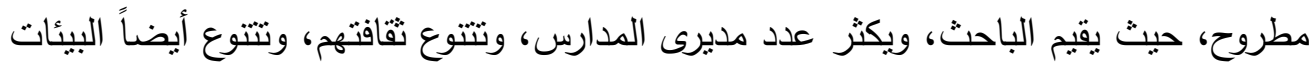
من زراعية، وتجارية، وصناعية، وصحراوية، وساحلية، ولئه

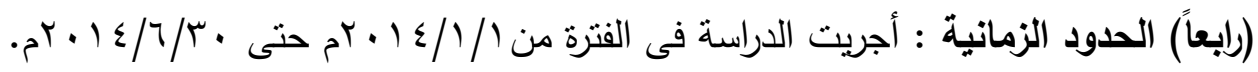

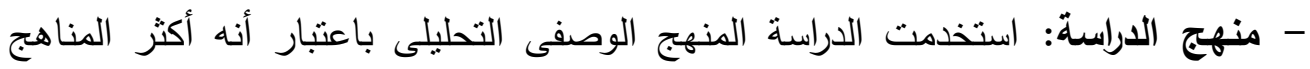

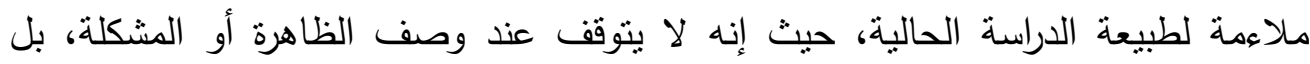

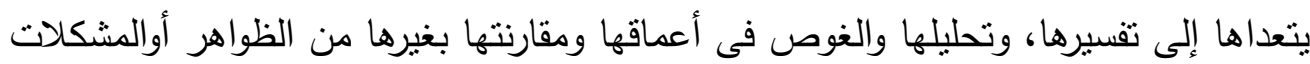

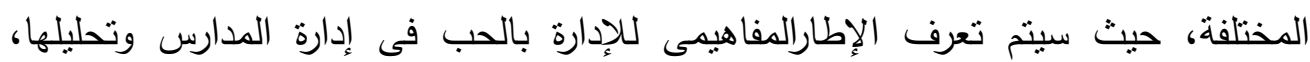

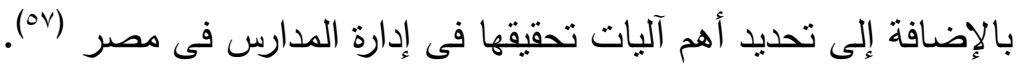

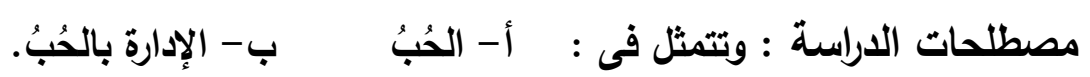

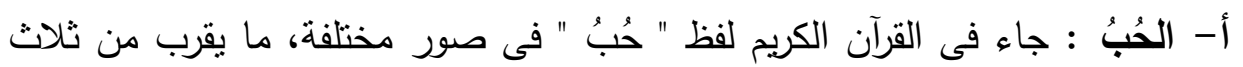

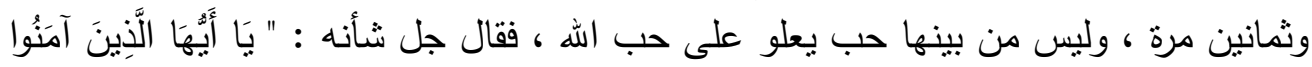

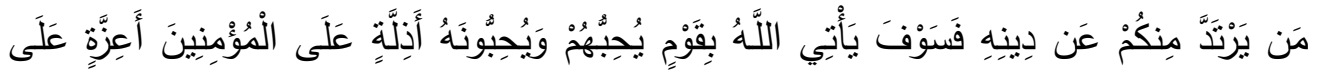

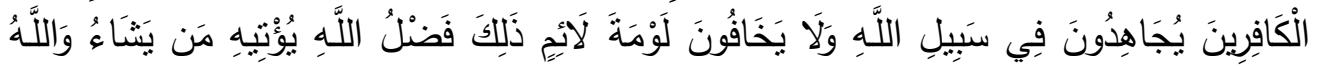

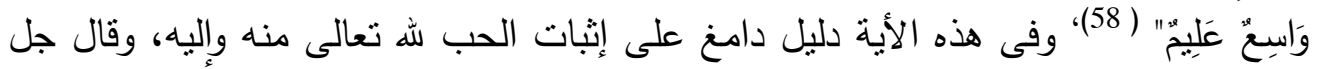

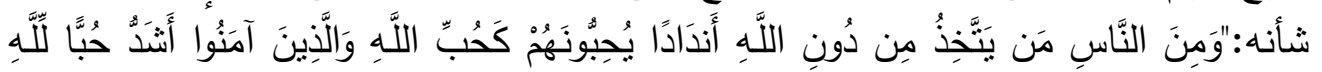

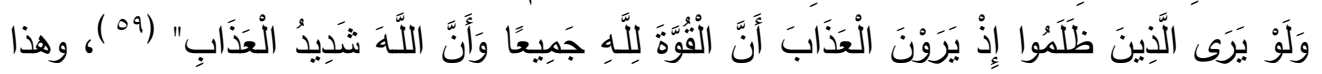

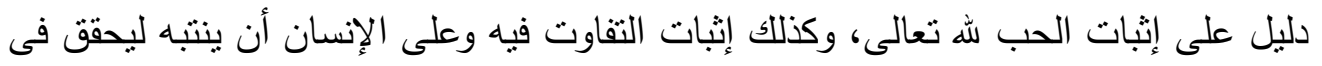

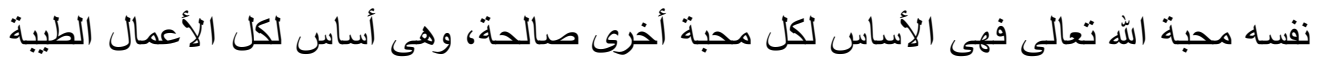

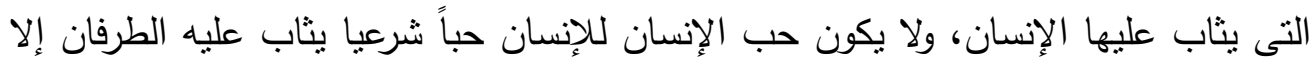

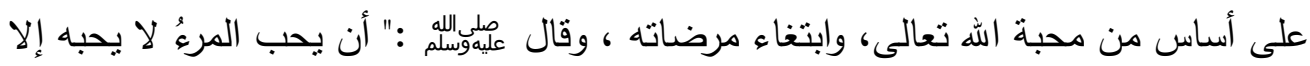

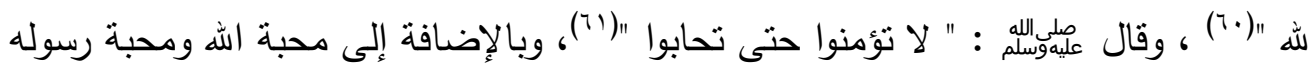

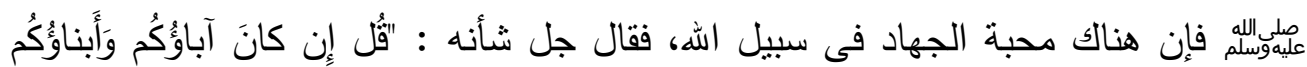

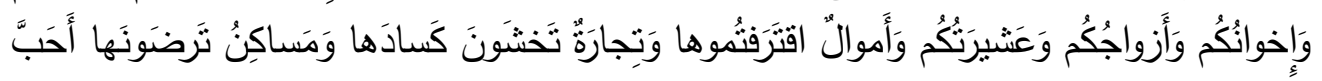




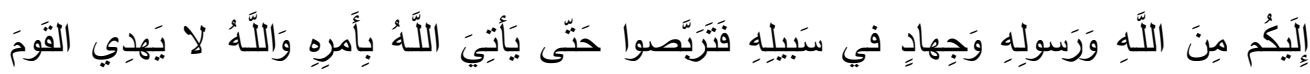

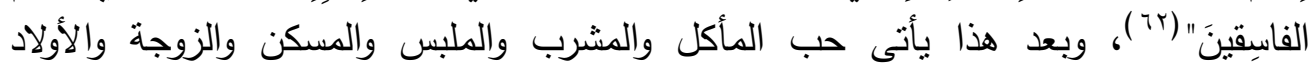

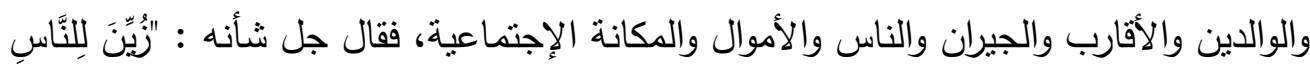

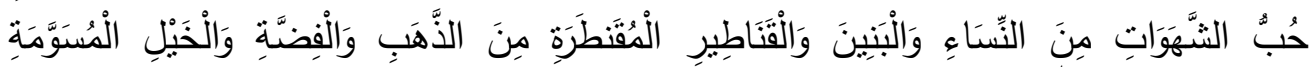

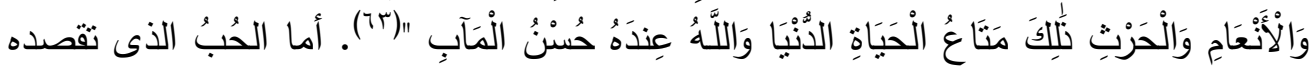

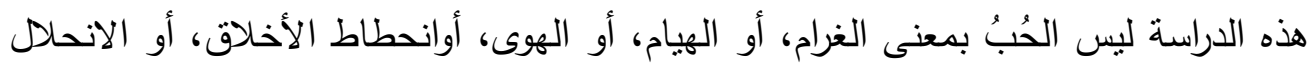

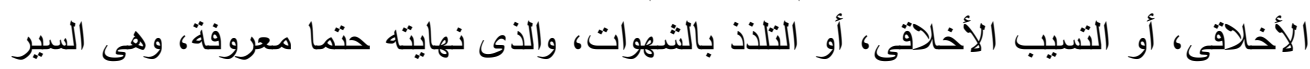

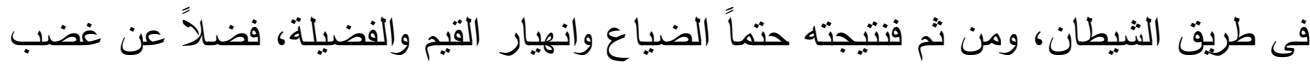

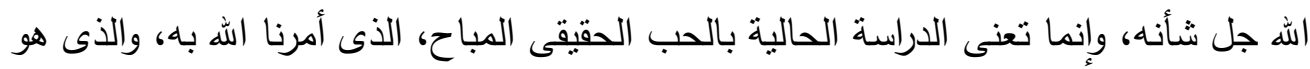

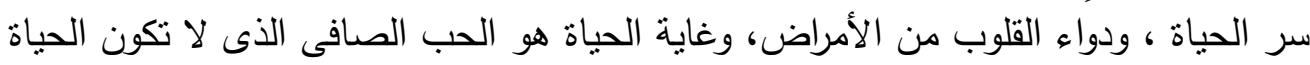

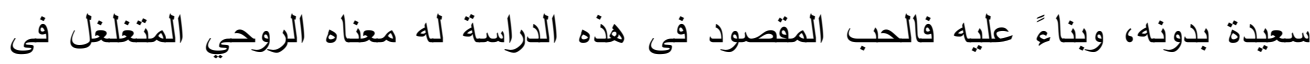

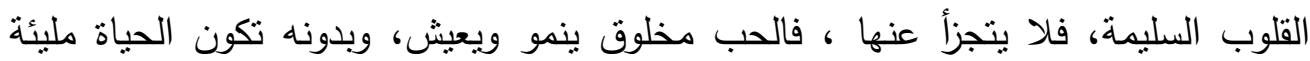

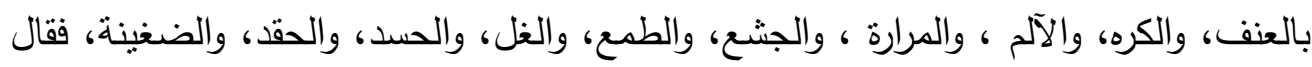

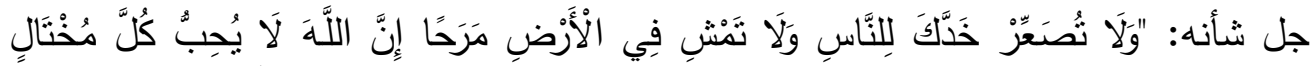

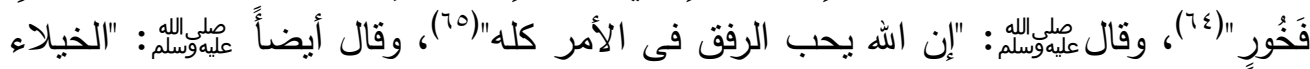

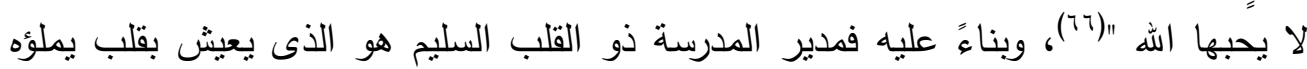

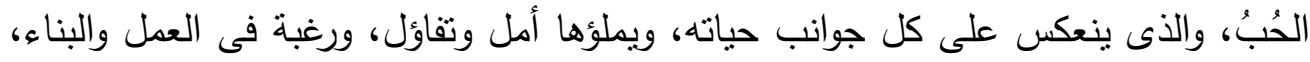

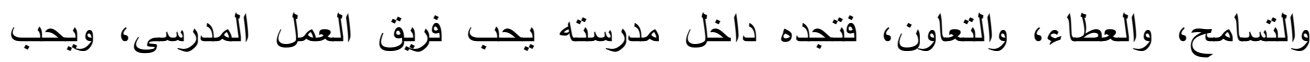

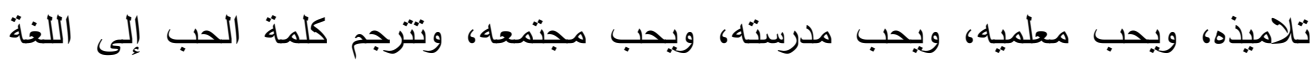
الإنجليزية " Love "، ويمكن توضيحها في ويح الجدول النالى :

جدول(0) ييين مكونات كلمة الحب

\begin{tabular}{|c|c|c|c|}
\hline نوع قدرات مدير المدرسة & بدايات لكلمات & حروف كلمة الحب & \\
\hline قدرة مدير المدرسة على الاستماع & Listening & $\mathrm{L}$ & \\
\hline قدرة مدير المدرسة على الملاحظة & Observing & $\mathrm{O}$ & r \\
\hline قدرة مدير المدرسة على تقدير القيمة & Valuing & V & $r$ \\
\hline قدرة مدير الددرسة على المؤازرة & Empowering & $E$ & 2 \\
\hline
\end{tabular}

المصدر: ( من إعداد الباحث )

وبناءً على ذلك يمكن وضع التعريف الإجرائى للحب بأنه:" استجابات الدفء والتواد

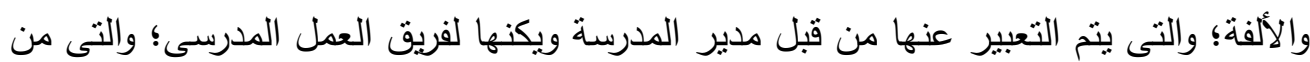

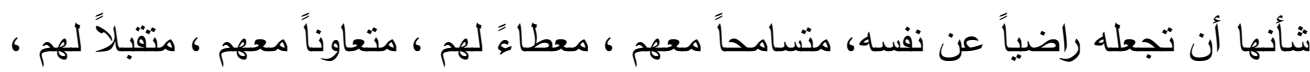
ومشباً لغريزة الحب الطبيعية لديه ". 


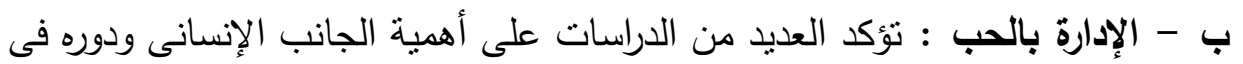

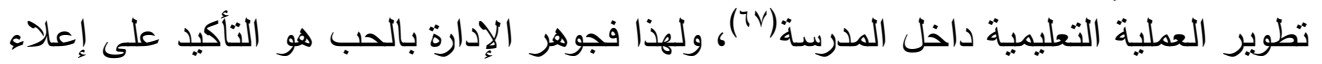

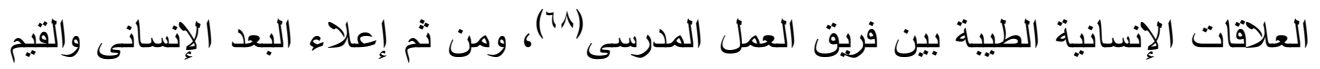

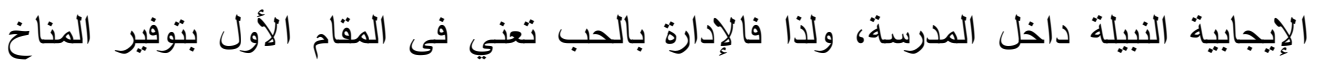

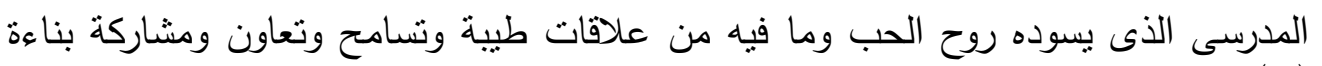

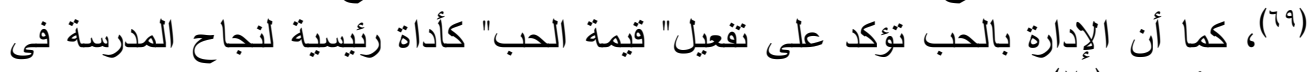

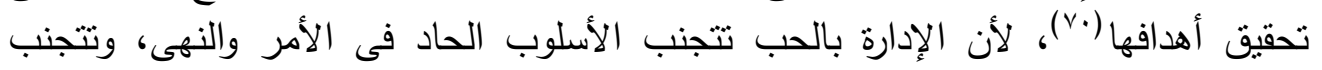

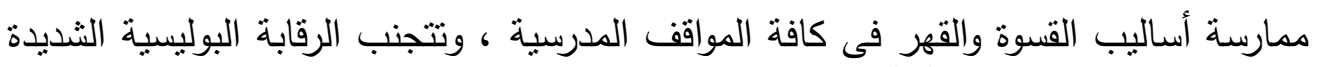

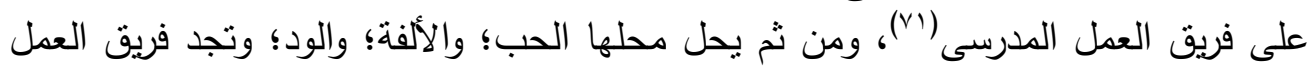

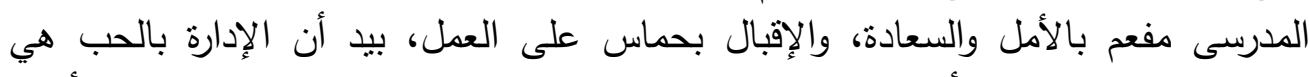

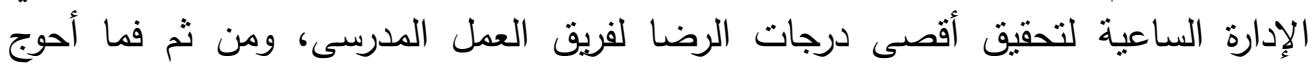

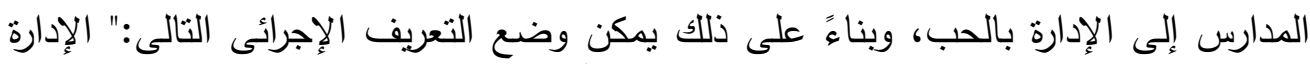

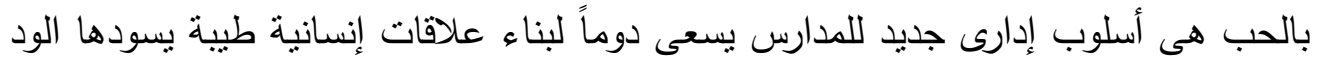

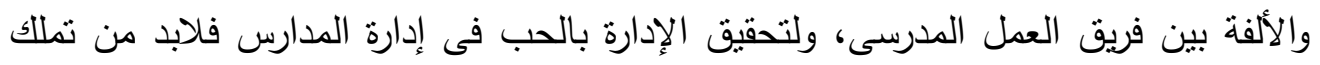

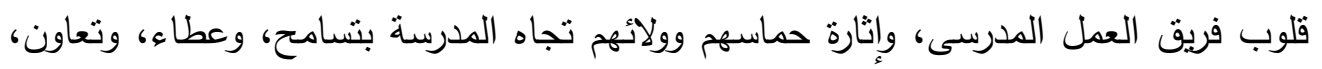

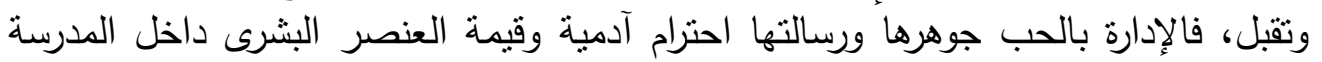

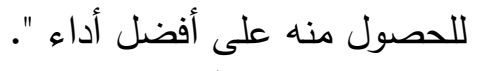

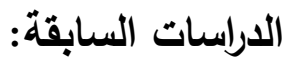

نظرا لأن موضوع الدراسة الحالية من الموضوعات الجديدة فى مجال الإدارة المدرسية -

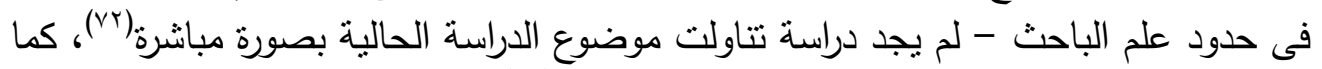

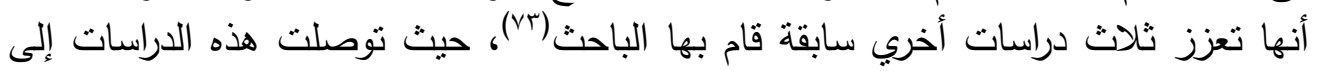

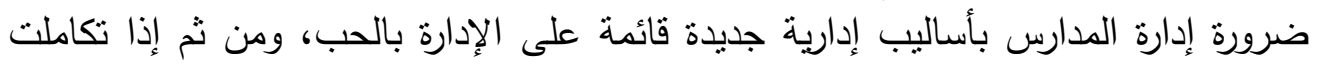

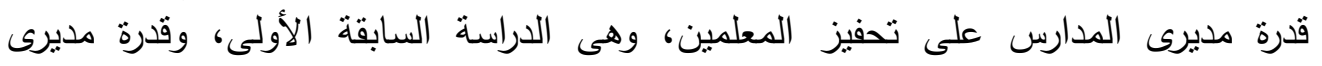

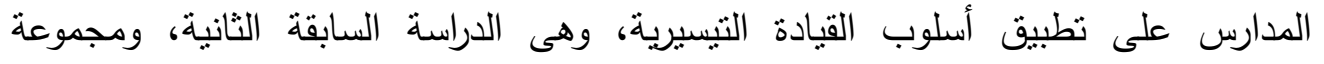

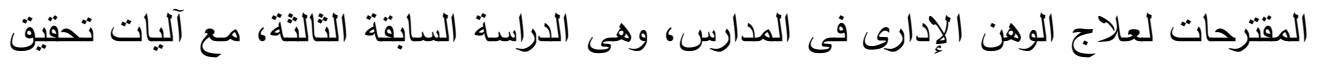

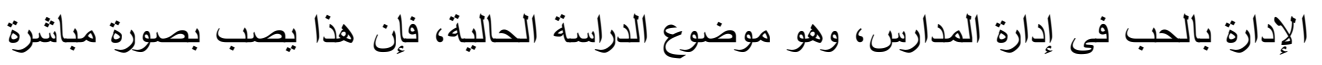

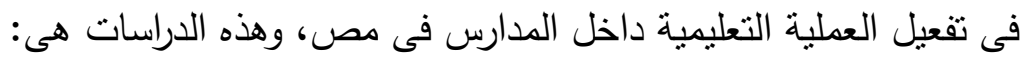

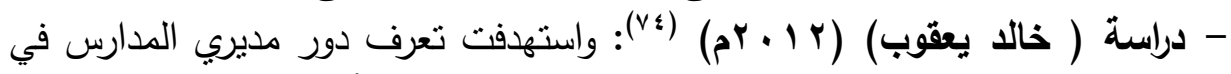

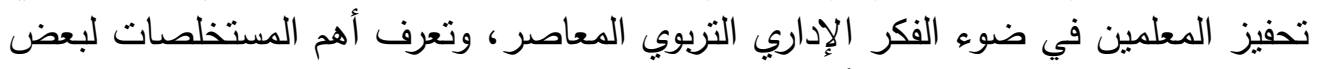

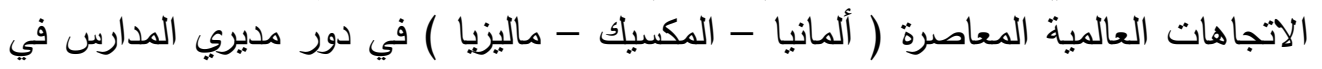

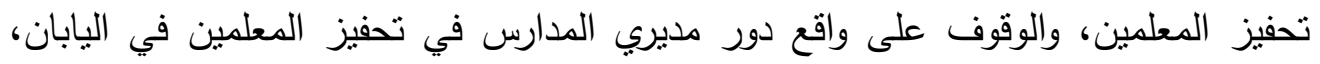

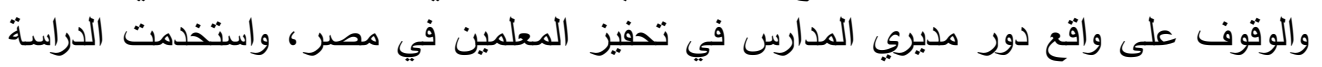

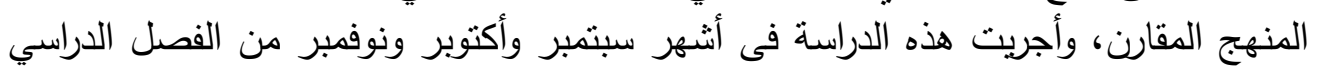




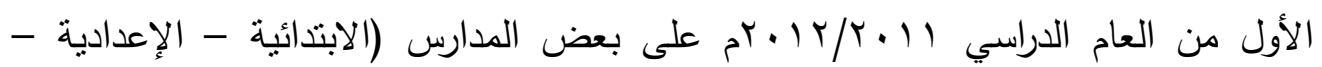

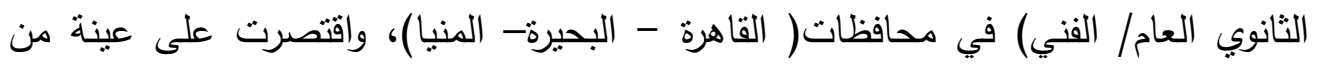

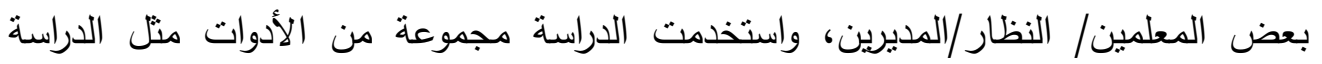

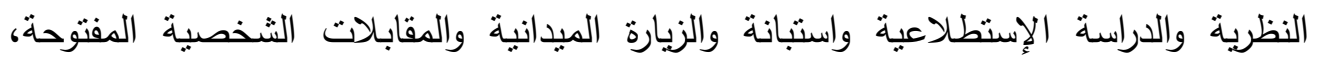

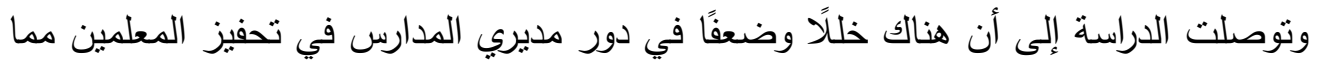

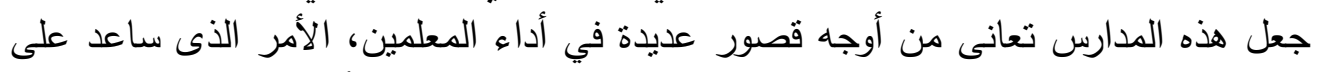

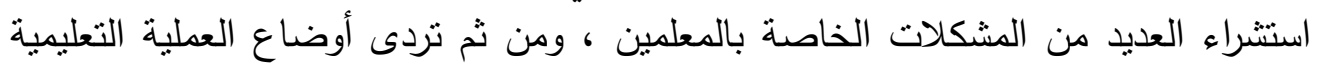

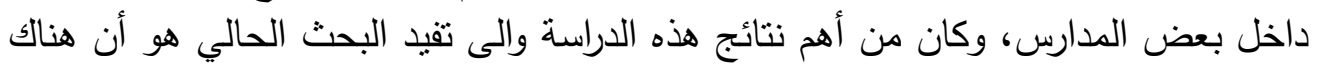

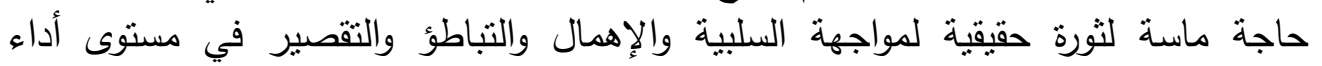

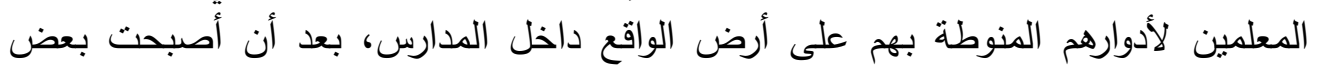

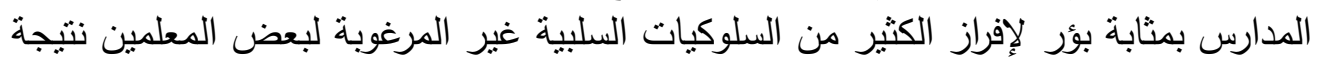

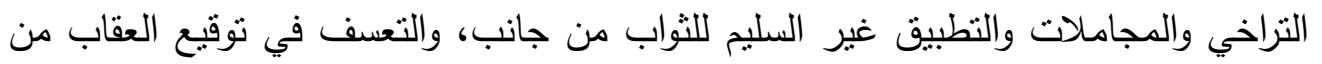

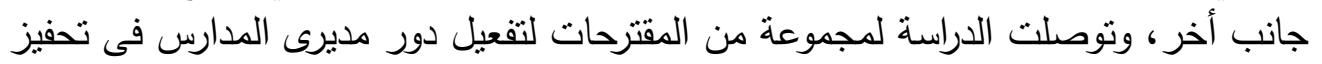

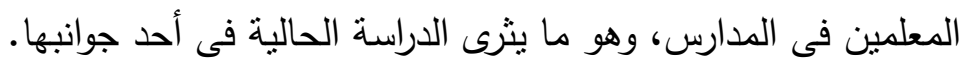

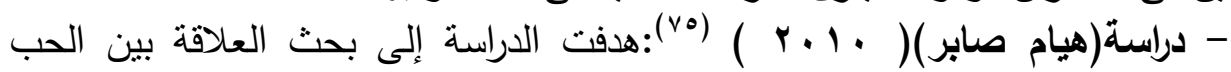

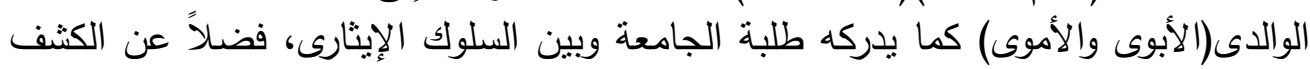

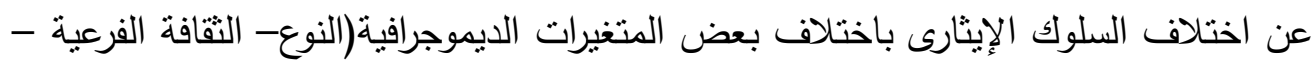

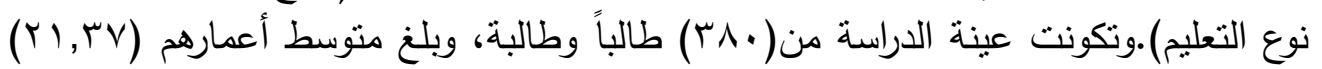

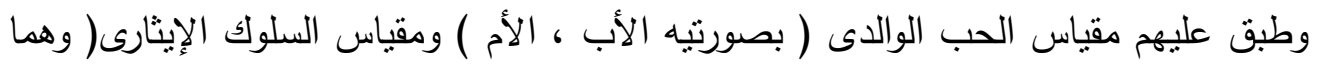

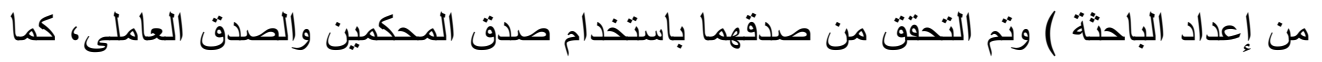

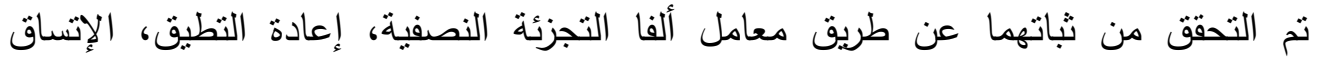

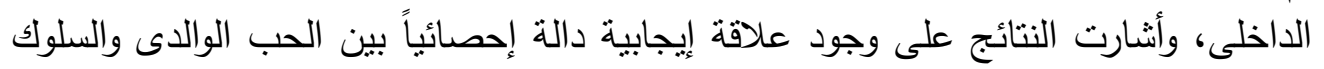

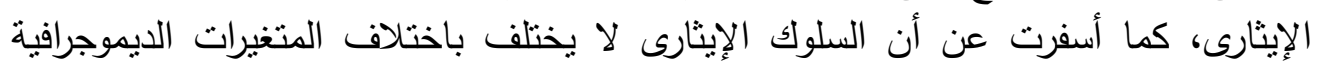

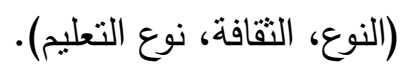

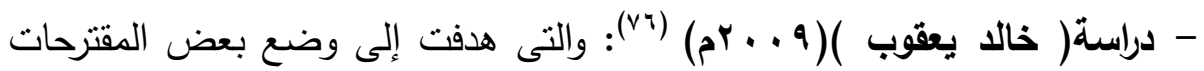

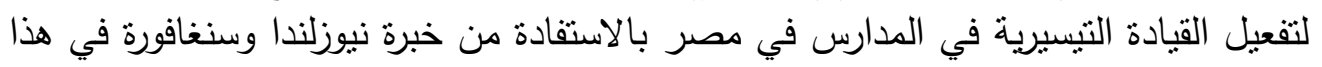

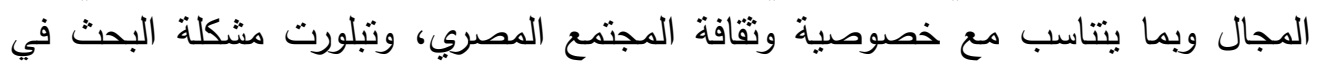

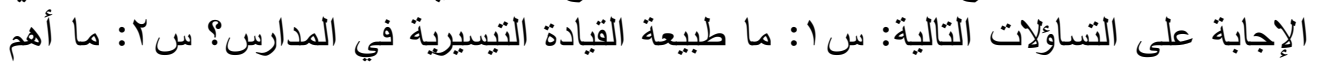

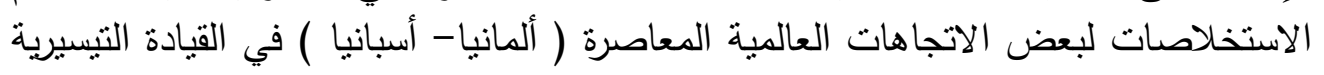

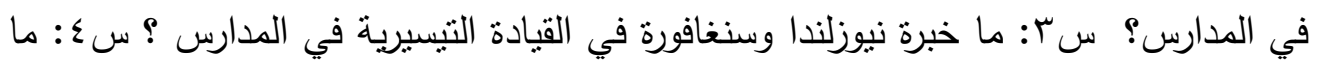

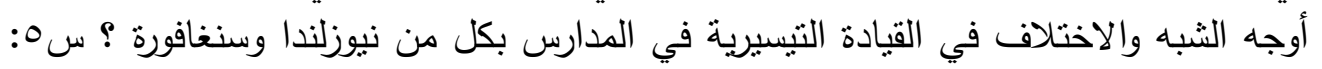

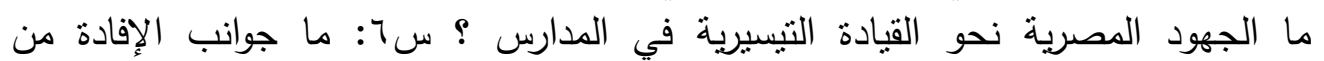
الاتجاهات العالمية المعاصرة وخبرة دولتي المقارنة ( نيوزلندا وسنغافورة) في القيادة التيسيرية 


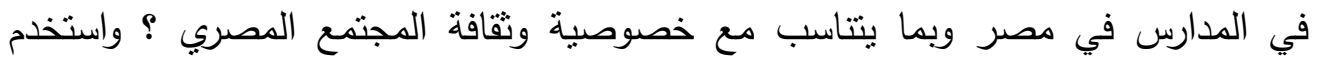

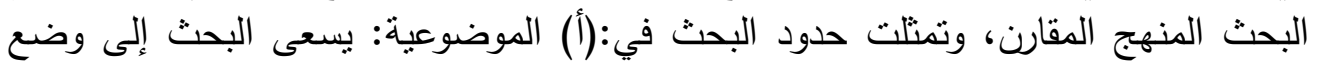

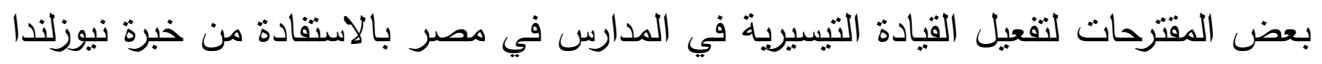

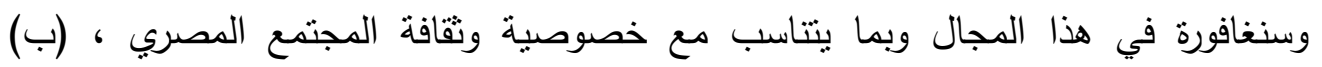

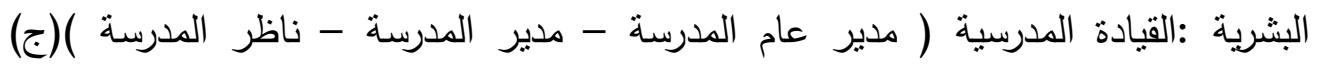

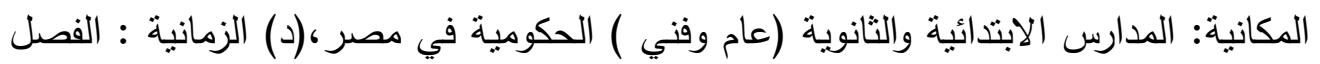

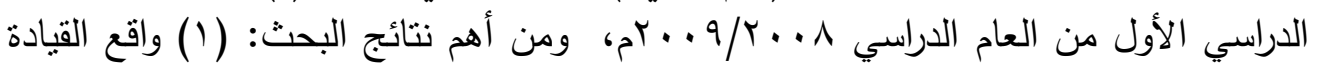

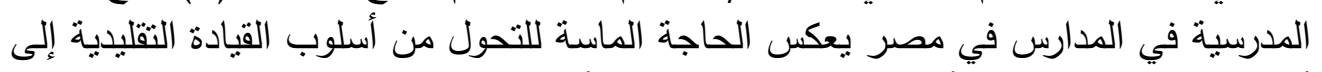

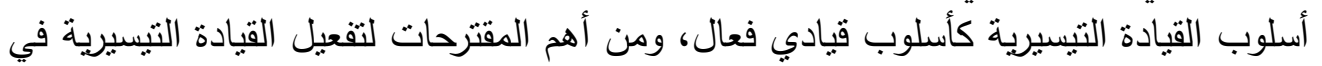

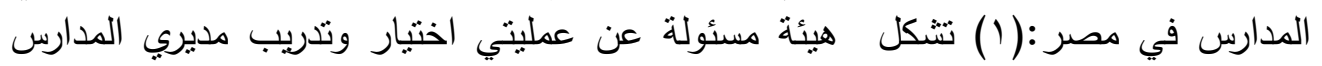

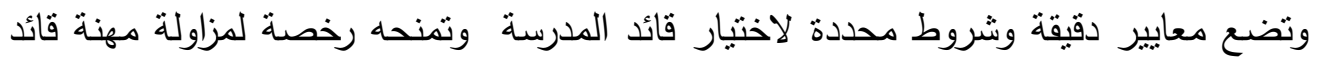

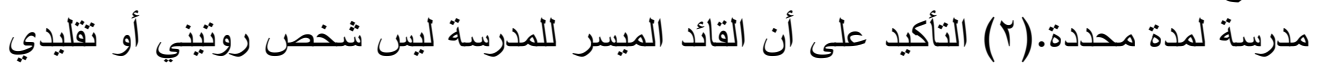

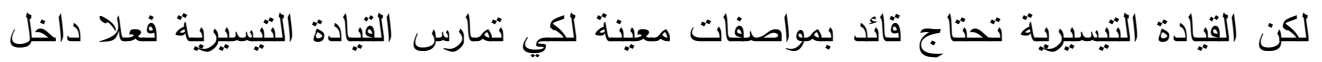

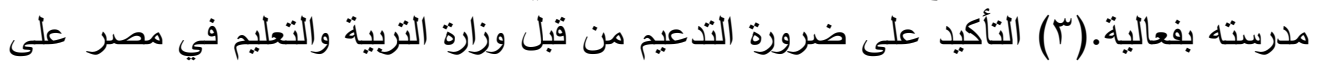

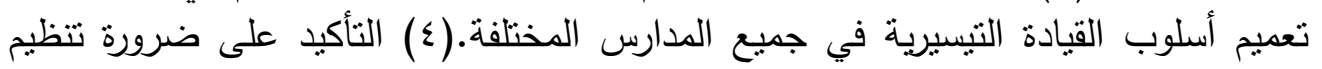

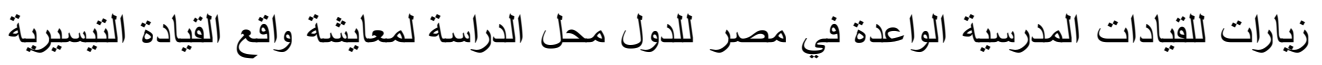
في المدارس، وهو ما يثرى الدراسة الحالية فى أحد جوانبها.

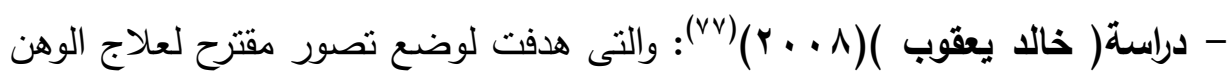

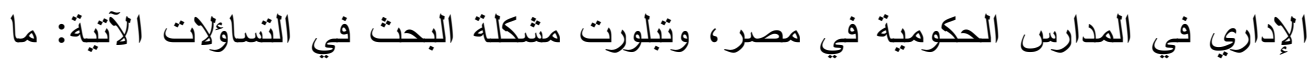

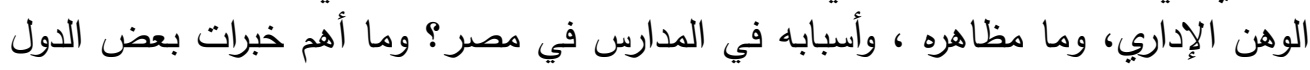

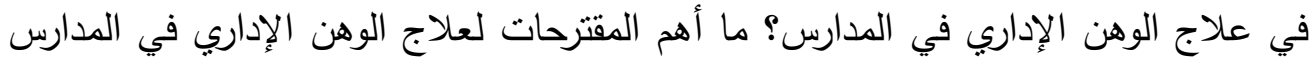

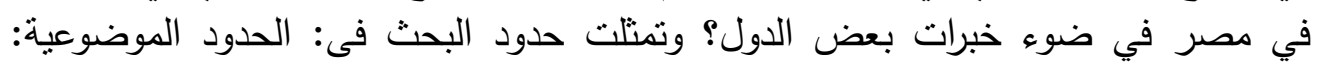

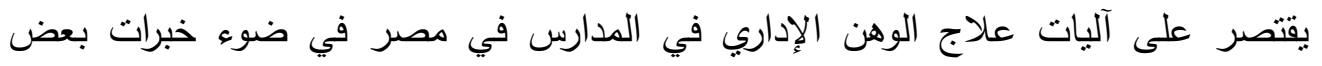

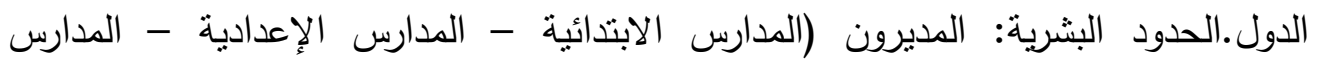

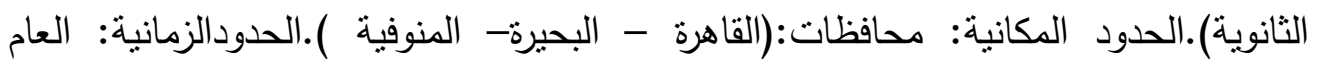

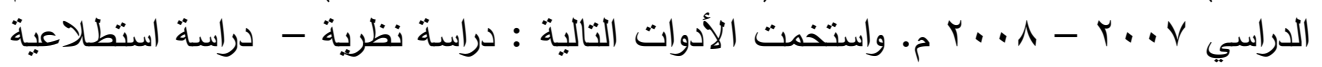

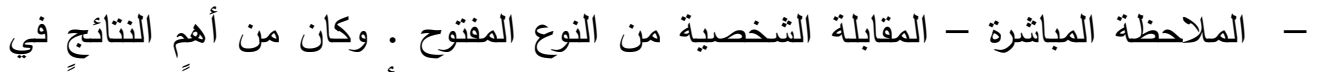

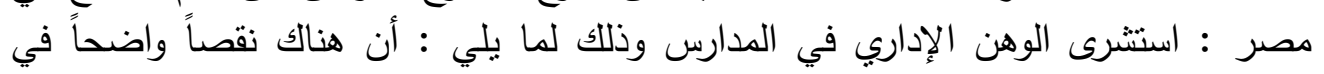

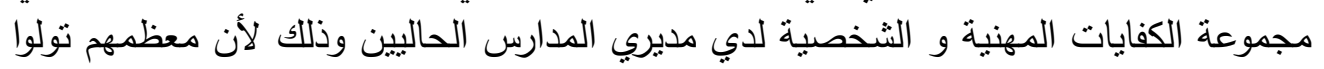

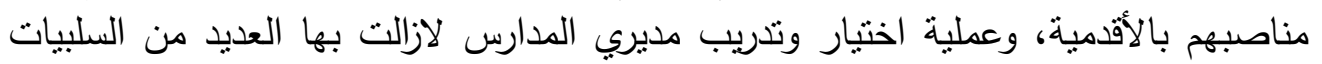

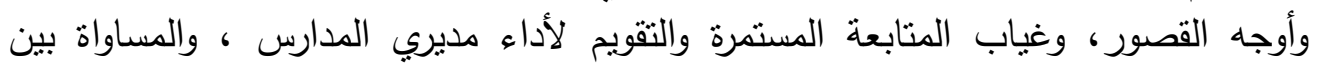

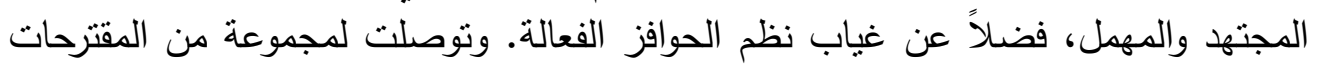
لعلاج الوهن الإداري في المدارس في مصر منها: إعادة النظر في نظام تدريب القيادات 


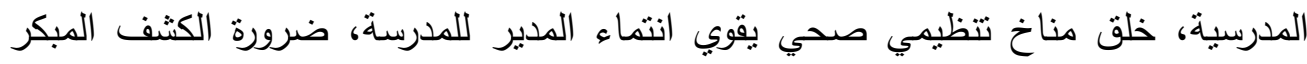

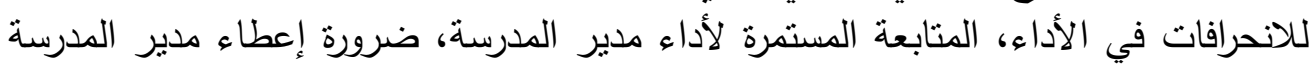
صلاحيات واسعة في مدرسته، وهو ما يثرى الدراسة الحابعة الحالية فى أحد جوانبها.

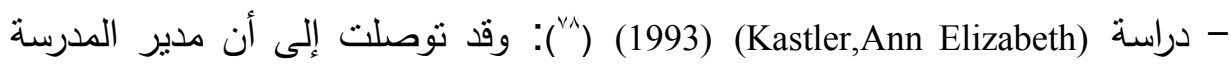

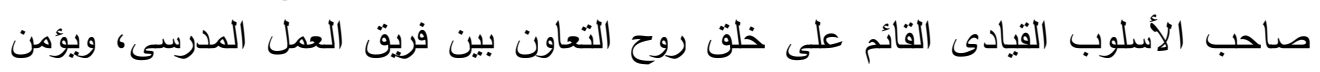

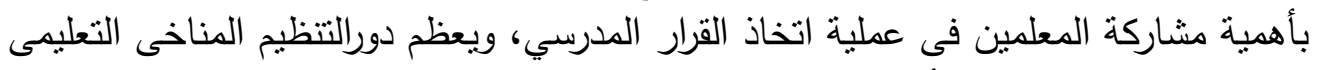

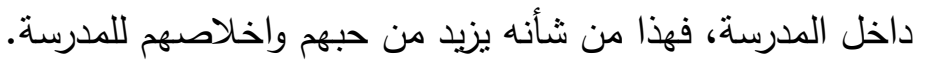
- تعليق عام على الاراسات السابقة: مما سبق عرضه يتبين أن الدراسة الحالية هي مطلب الدابة ونتاج الدراسات السابقة الثنالث

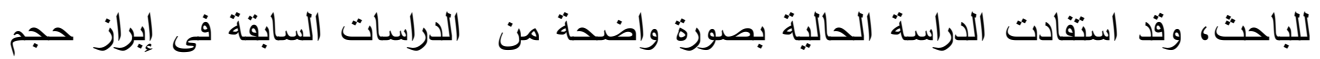

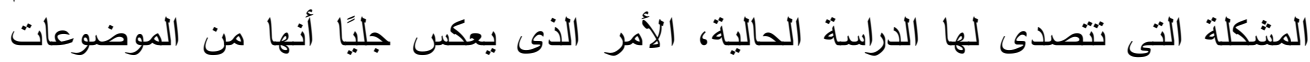

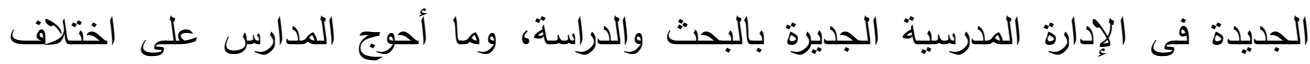

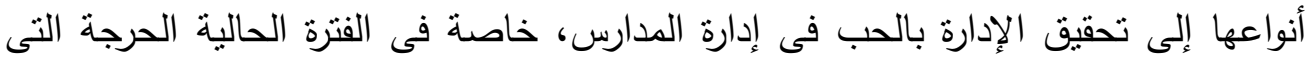

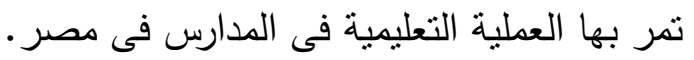

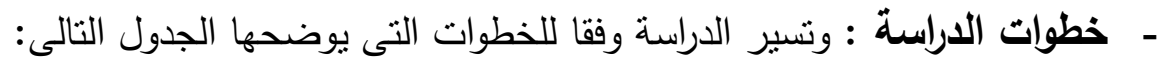

جدول (†) يبين خطوات سير الدراسة

\begin{tabular}{|c|c|}
\hline خطوات الاراسة & م \\
\hline الإطار المفاهيمي للإدارة بالحب في إدارة المدارس. & 1 \\
\hline أهم مبررات تز ايد الحاجة للإدارة بالحب فى إدارة المدارس فى مصر. & r \\
\hline أهم عناصر تحقيق الإدارة بالحب فى إدارة المدارس فى مصر. & $r$ \\
\hline أهم صفات مدير المدرسة الذى يحقق الإدارة بالحب فى إدارة المدارس فى مصر. & $\varepsilon$ \\
\hline أهم آليات تحقيق الإدارة بالحب فى إدارة المدارس فى مصر. . & 0 \\
\hline
\end{tabular}

الخطوة الأولى: الإطار المفاهيمي للإدارة بالحب فى إدارة المدارس: وهو:

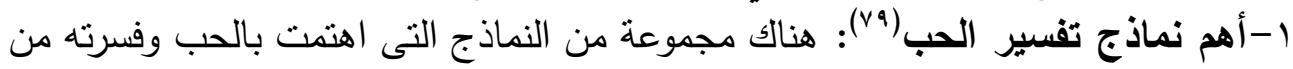

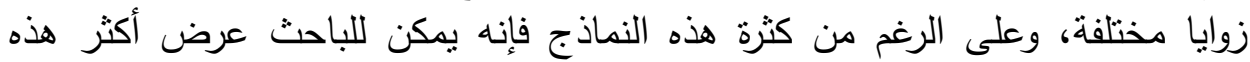

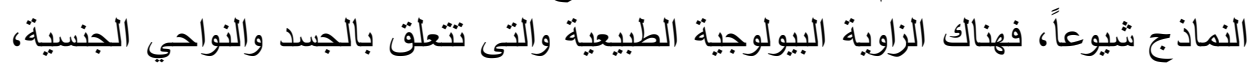

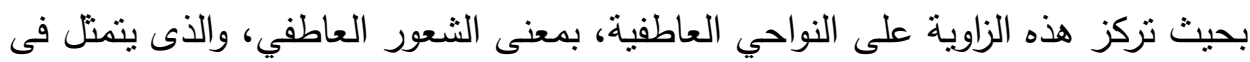

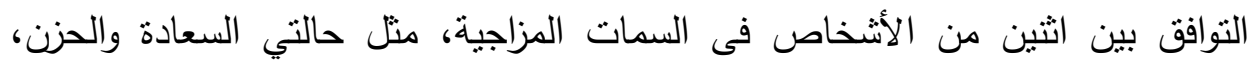

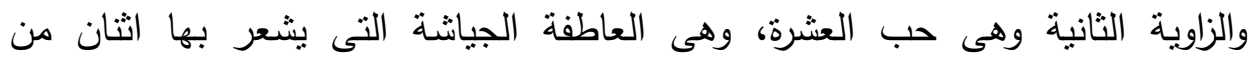

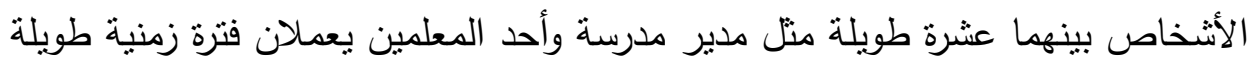

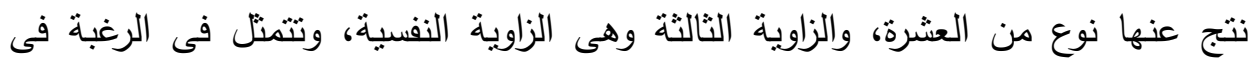

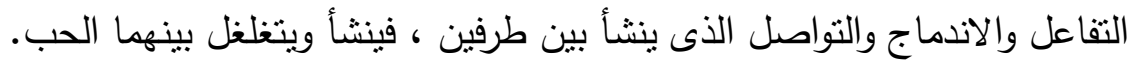




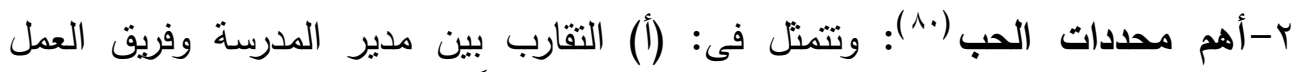

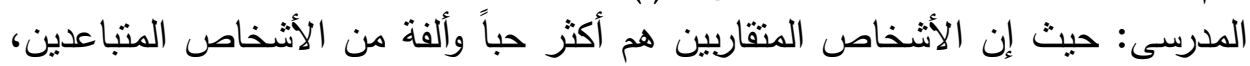

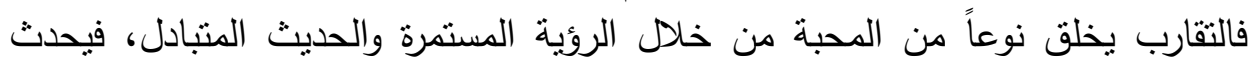

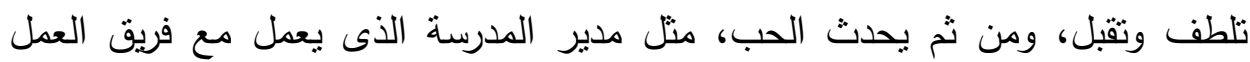

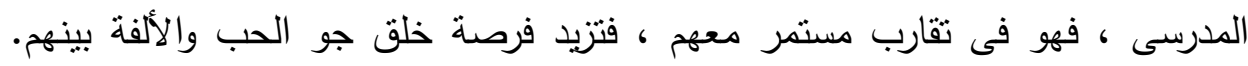

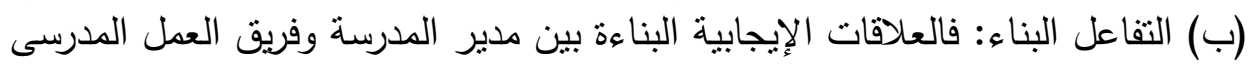

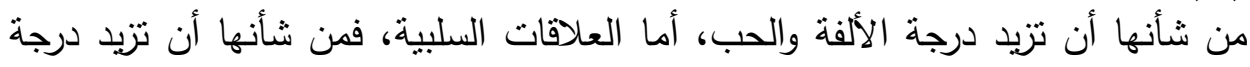

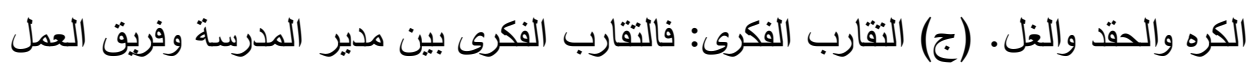

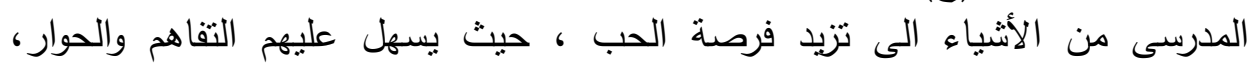

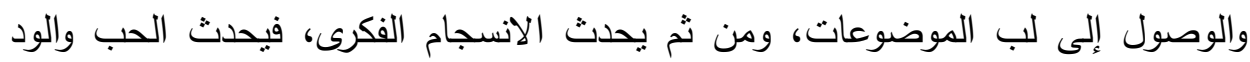
والتقبل . r-لماذا ريط مفهوم الإدارة بمفهوم الحب؟: بادىء ذي بدء ينبغى التسليم بأنه من أنبل

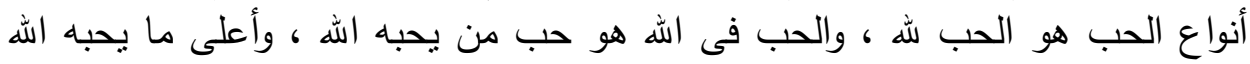

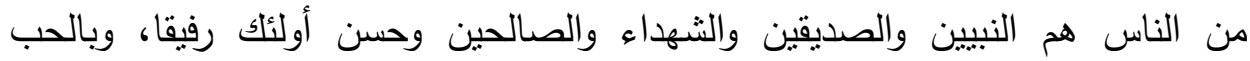

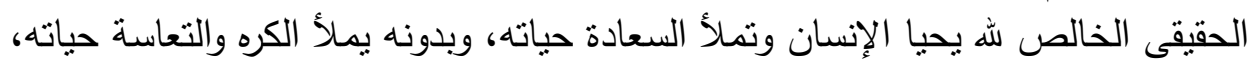

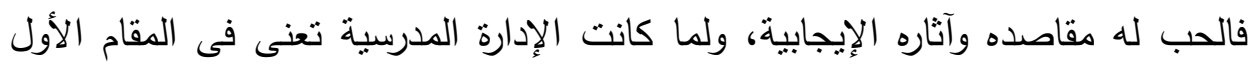

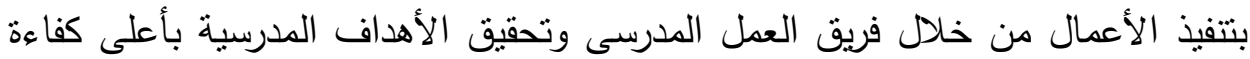

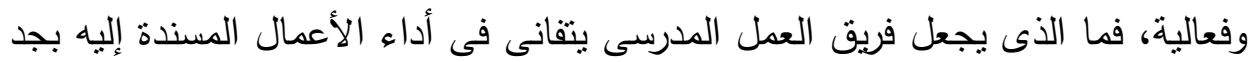

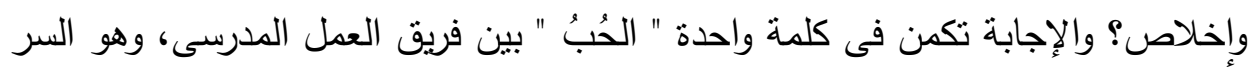

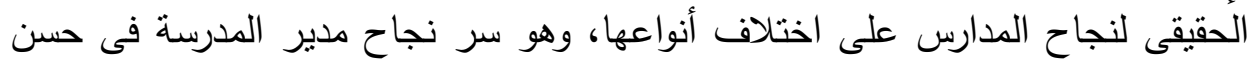

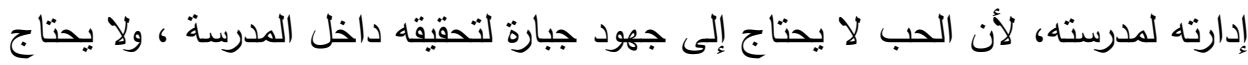

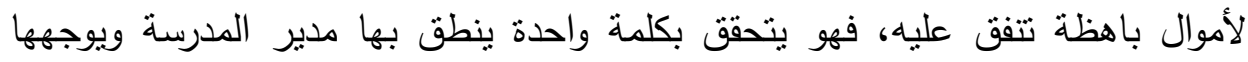

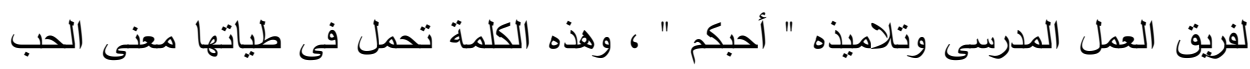

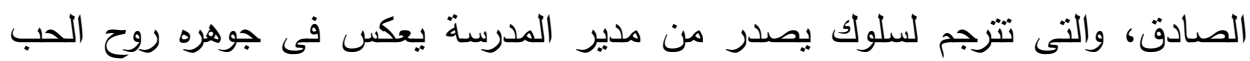

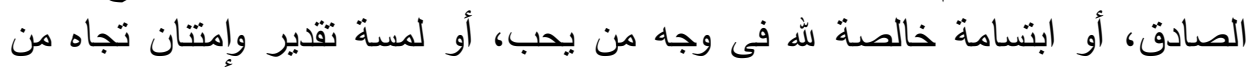

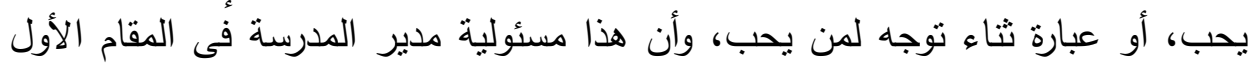

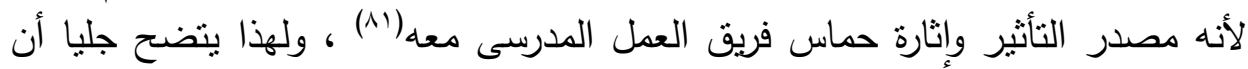

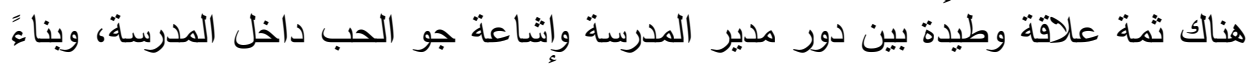

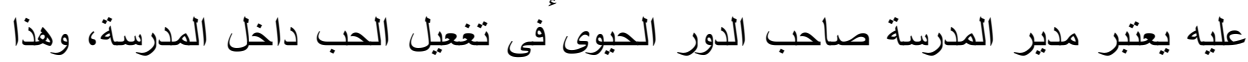

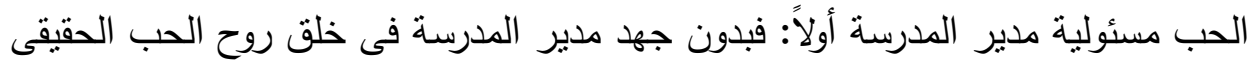

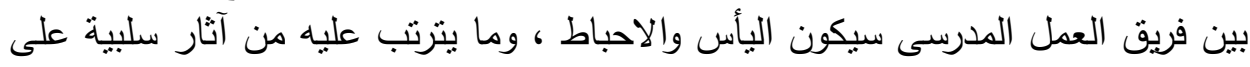

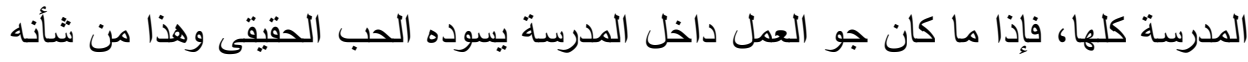

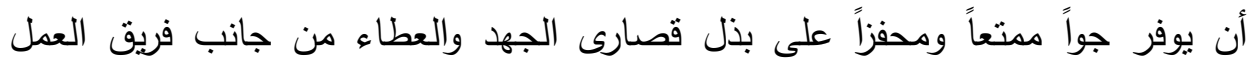

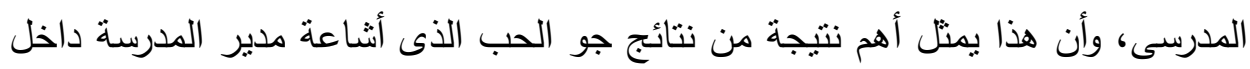


مدرسته، فالحب الصادق هو أساس تحقيق هذا الجهد والعطاء ، كما أن الحب وما يحمله

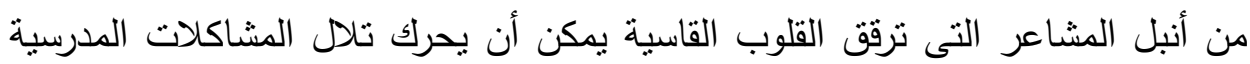

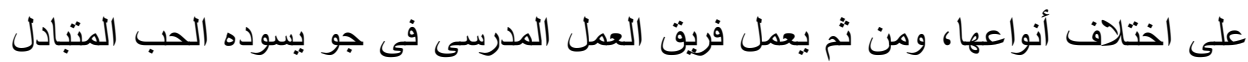

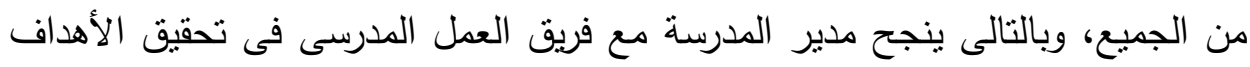

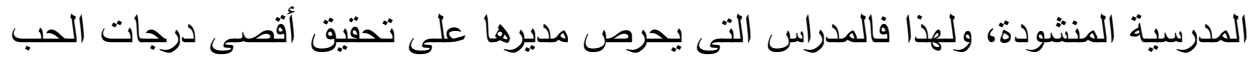

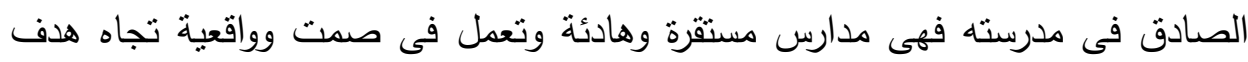

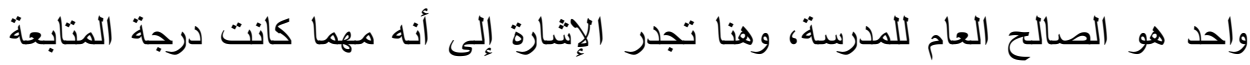

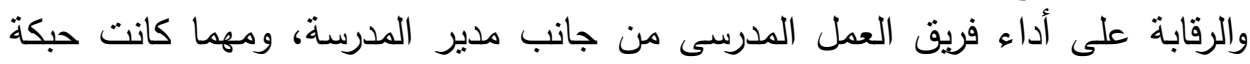

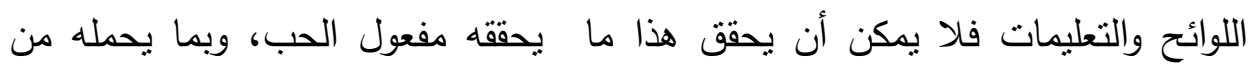

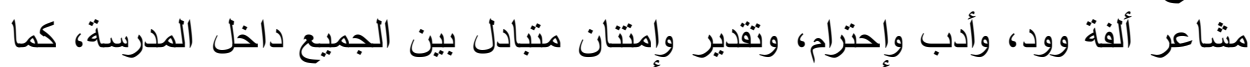

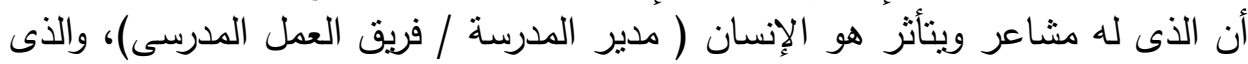

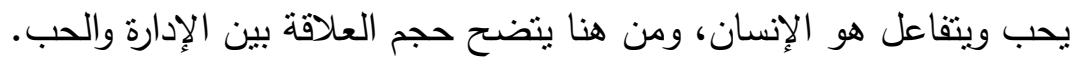

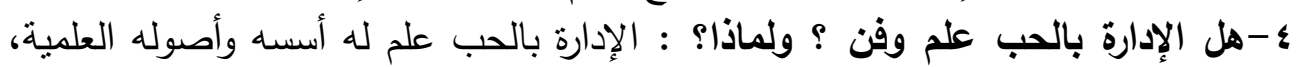

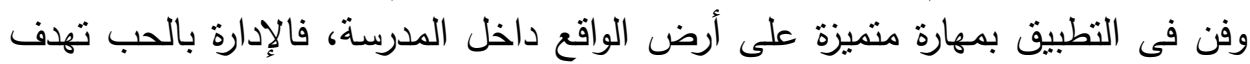

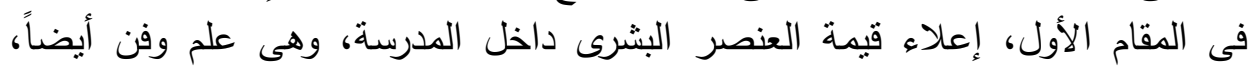

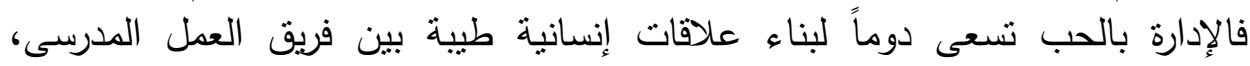

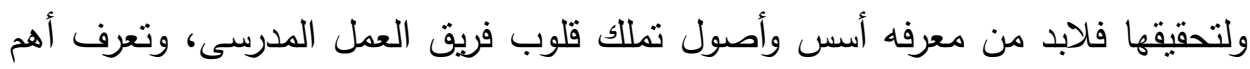

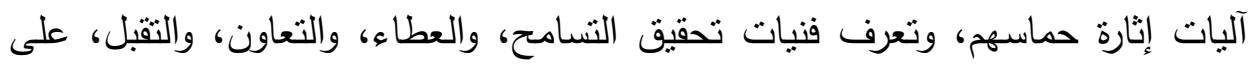
أرض الواقع داخل المدرسة. ه-أسس الإدارة بالحب داخل المدرسة: ويمكن عرضها فى سياق الجدول التالى :

جدول (V) يبين أسس الإدارة بالحب داخل المدرسة

\begin{tabular}{|c|c|c|}
\hline المدة الزمنية & نوع الحب & ? \\
\hline طو ال العام & حب مدير المدرسة لمدرسته & الأساس الأول \\
\hline طو ال العام & حب مدير المدرسة لمعلميه & الأساس الثانى \\
\hline طو ال العام & حب مدير المدرسة لتلاميذه & الأساس الثالث \\
\hline طو ال العام & حب مدير المدرسة المدرسة لفريق العمل المدرسى & 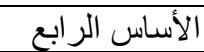 \\
\hline طو ال العام & حب مدير المدرسة للمجتمع المحيط بالمدرسة & الأساس الخامس \\
\hline طو ال حياته & حب مدير المدرسة لنفسه ( الحب الخالى من الأنانية ) & الأسـاس السادس \\
\hline
\end{tabular}

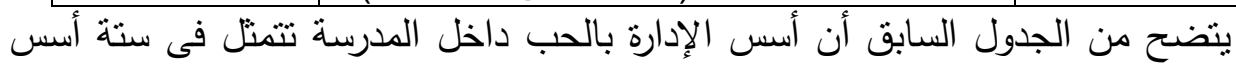

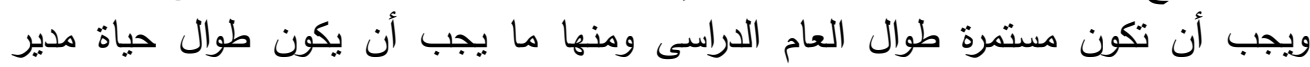

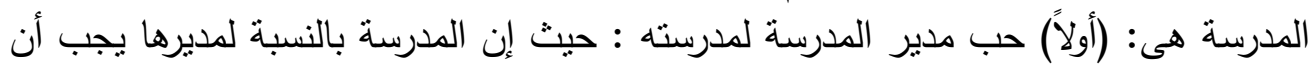

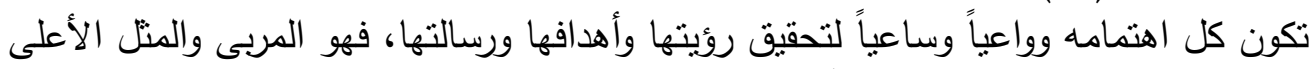

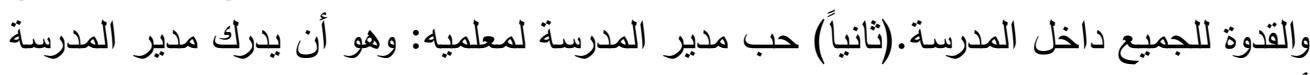

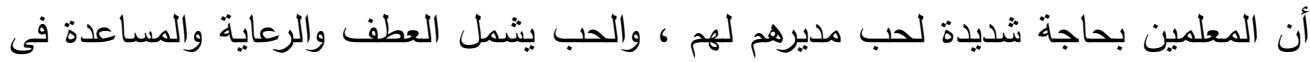


مواجهة الصعاب، وبالتالى فالإدارة بالحب هي بلسم يقدمه مدير المدرسة لمعلميه، لأن جوهر

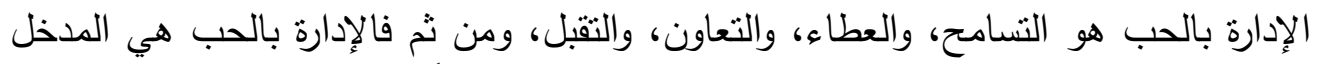

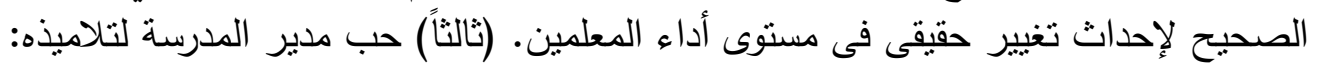

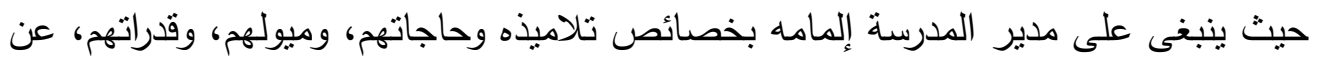

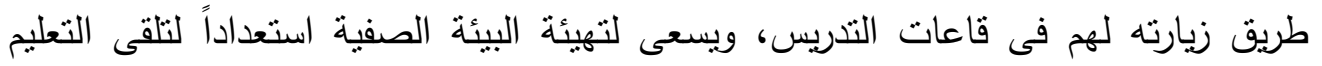

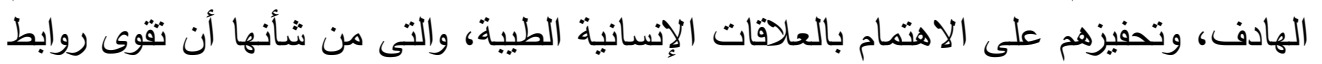

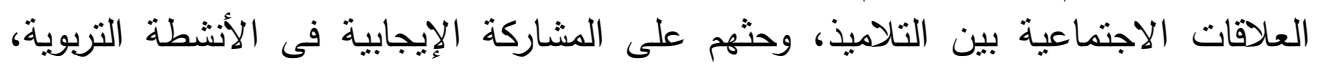

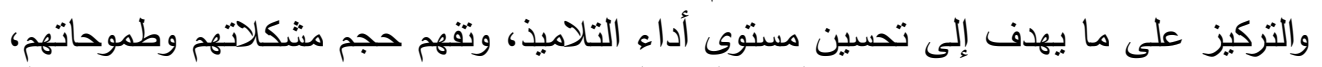

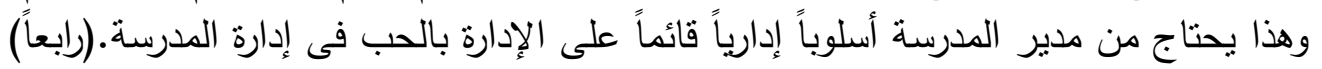

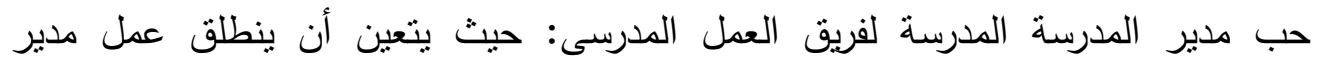

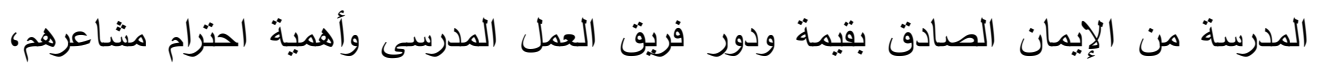

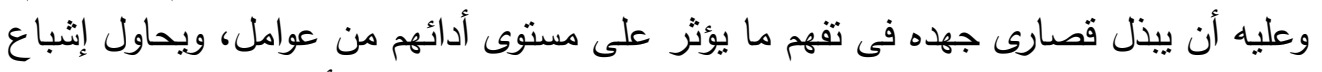

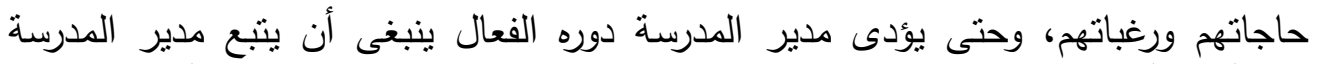

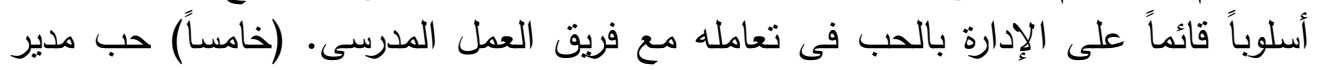

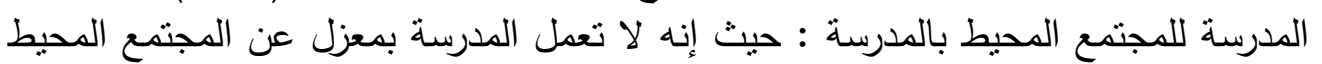

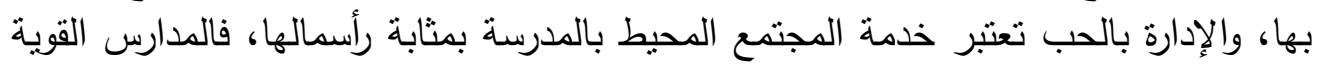
هى التى تحرص على الادرة بالتلاحم مع المجتمع المحيط بها وتخلق العلاقات الطيطة الطية معهد.(سادساً)

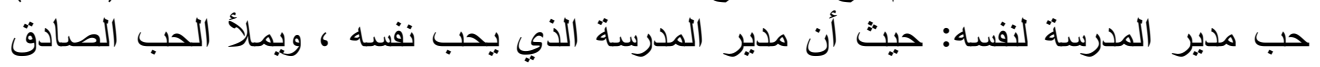

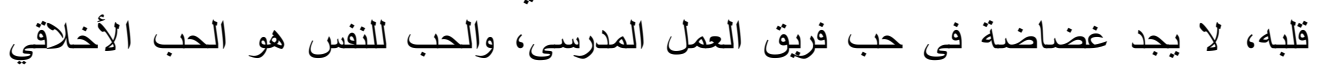

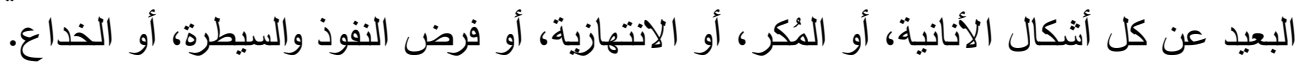

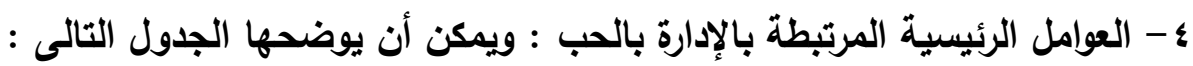

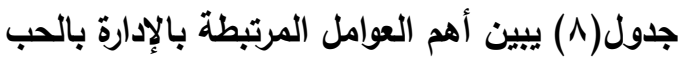

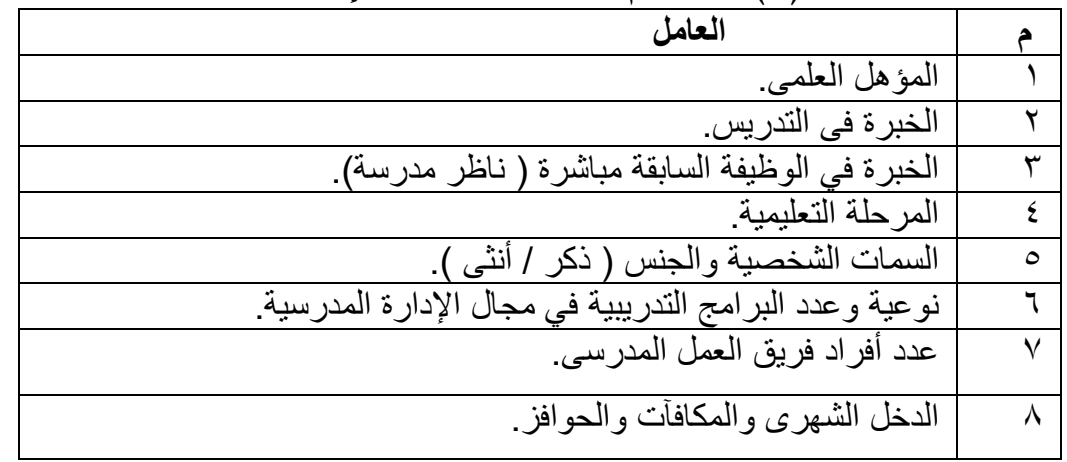

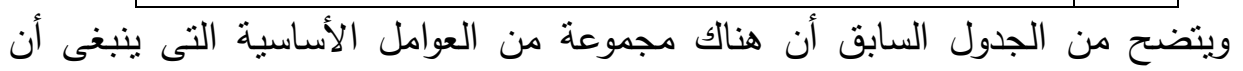

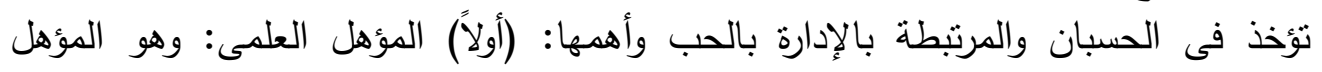

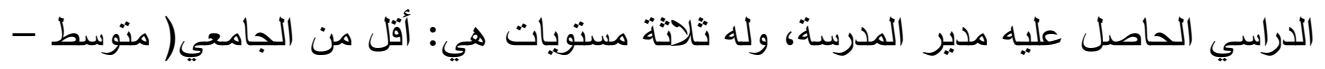
فوق منوسط )، جامعي( بكالوريوس- ليسانس )، فوق الجامعي( دبلوم دراسات عليا - 
ماجستير - دكتوراه). (ثانياً) الخبرة فى التدريس: وهى المدة التى قضاها مدير الددرسة في

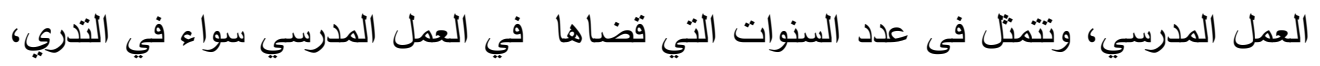

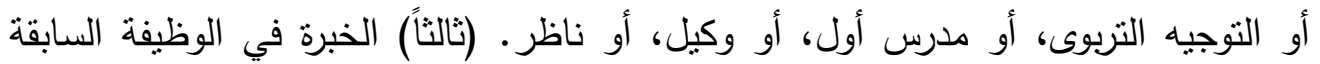

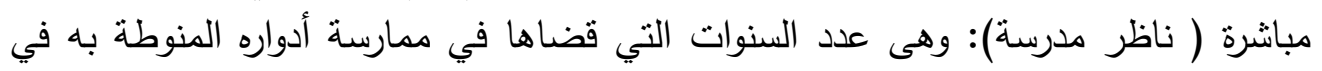

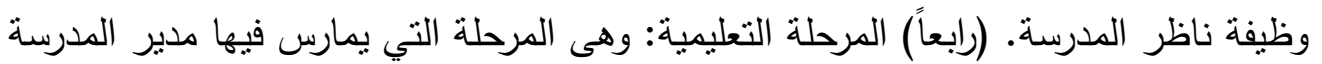

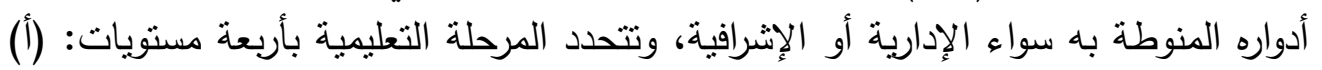

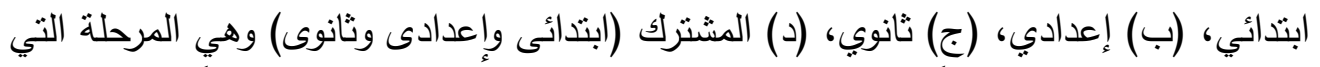

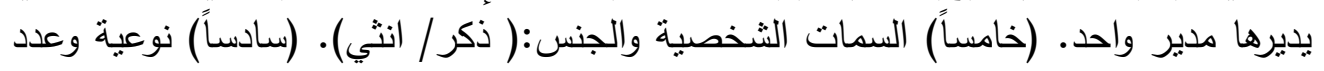

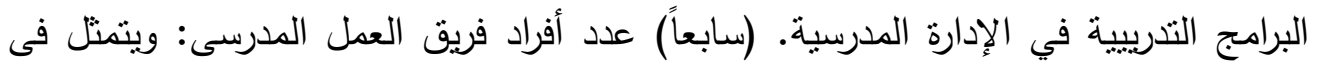

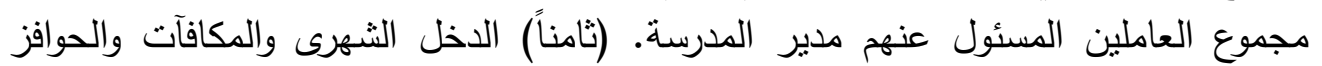

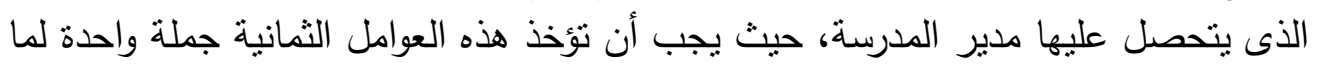
لهذه العوامل من تأثنير وبدرجات مختلفة على الإدارة بالحب في إلى إدارة المدارس.

الخطوة الثانية: مبررات تزايد الحاجة للإدارة بالحب فى إدارة المدارس فى مصر : وأهمها:

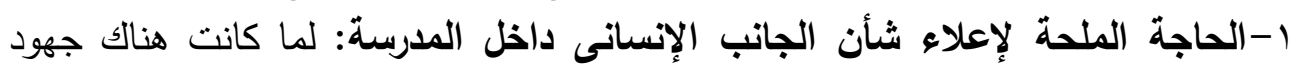

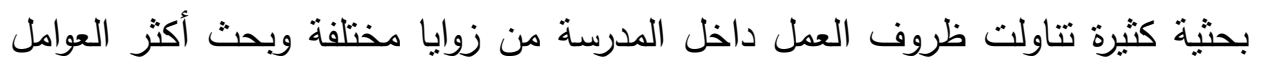

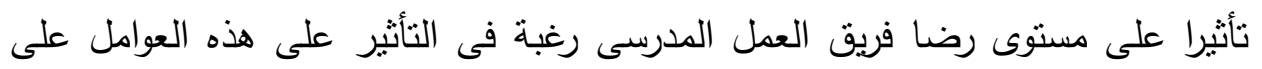

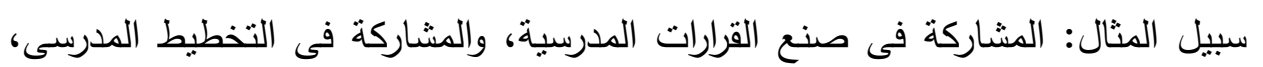

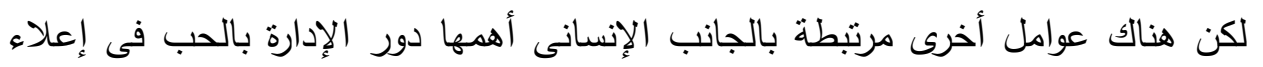

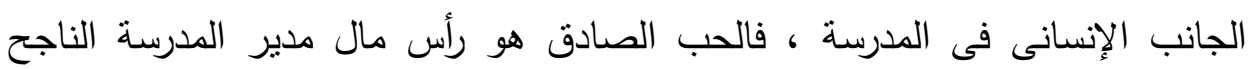

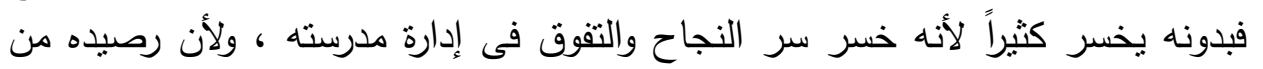

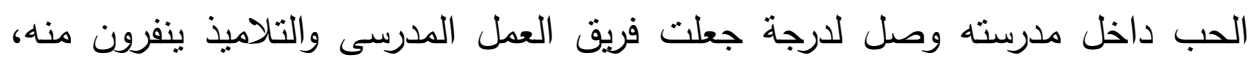

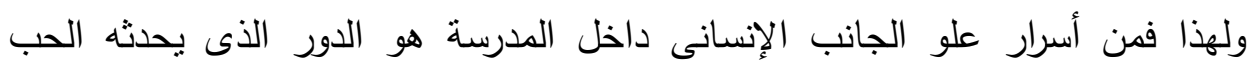
الصادق داخل المدرسة.

ץ- الحاجة الملحة لجنى ثمار الحب الصادق داخل المدرسة : فقد أكدت بعض الدراسات

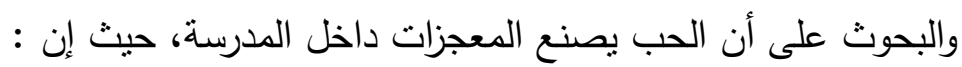

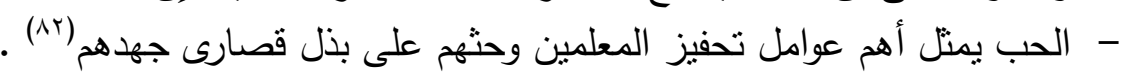

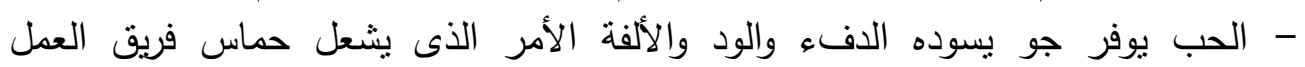

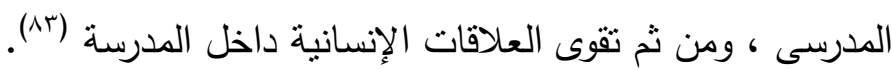

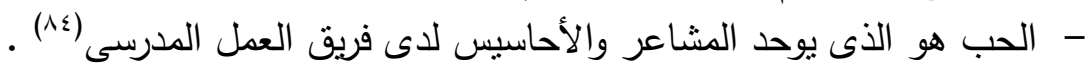

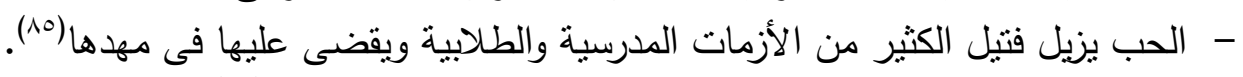

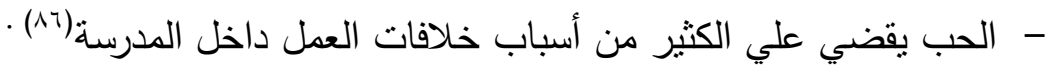

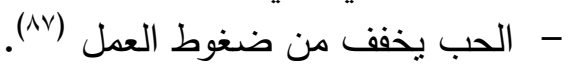


الخطوة الثالثة: عناصر تحقيق الإدارة بالحب فى دارة المدارس:

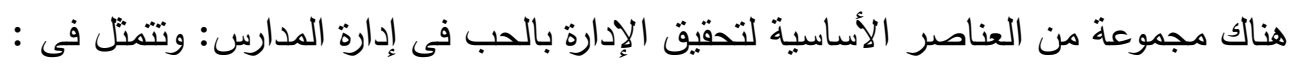

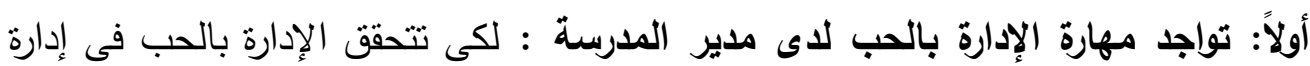

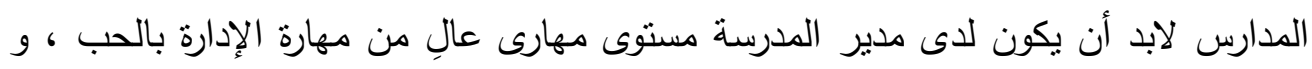

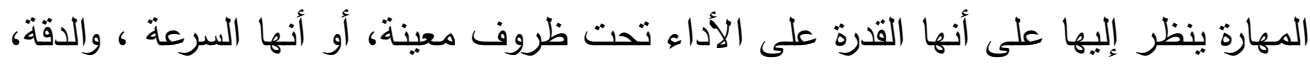

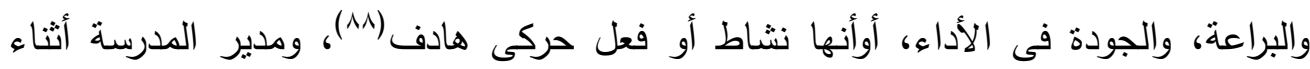

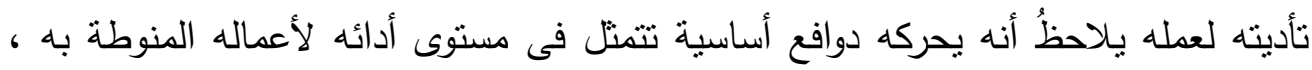

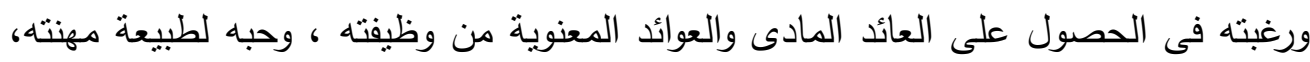
ومن ثم فنجاح مدير المدرسة فى غرس بذور الحب فى مدرسته سيكون حتماً نتيجته جنى ونى

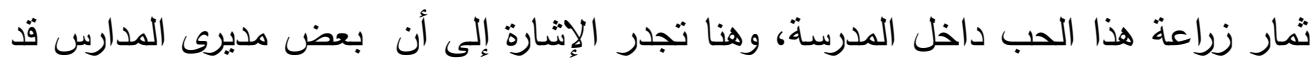

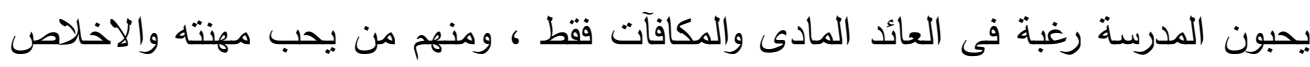

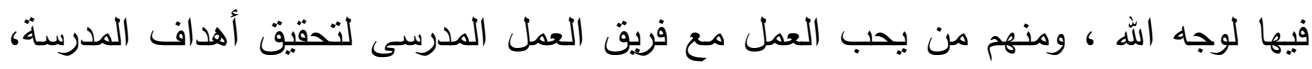

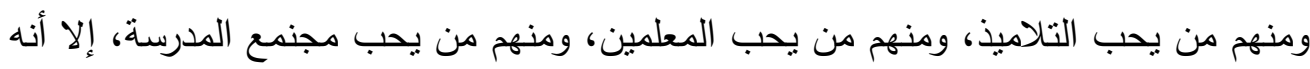
هناك بعض الصعوبات قد تواجه مديرى الددارس والتى تحتاج إلى مهارة ليتمكن من تذنليل

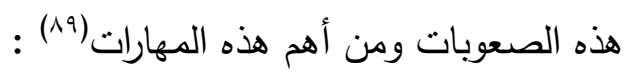

- مهارته فى تغيير النظرة الضيقة لطبيعة العمل داخل المدرسة على أنها فترة محددة بساعات عمل رسمية فقط دون أدنى اعتبار لتحسين العملية التعليمية . - خلق روح الحب فى تأدية الأعمال مع فريق العمل المدرسى.

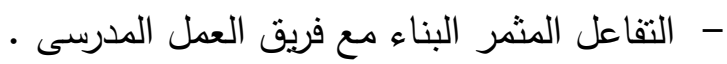
- التركيز على خلق روح التسامح بين فريق العمل المدرسى ل

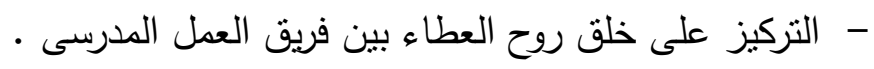
- التركيز على خلق روح التعاون بين فريق العمل المدرسى. - التركيز على خلق روح الدفه والفيز والود بين فريق العمل العلى المدرسى.

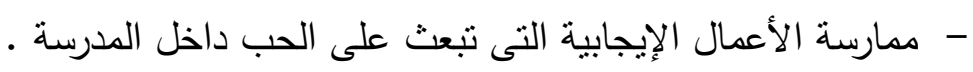

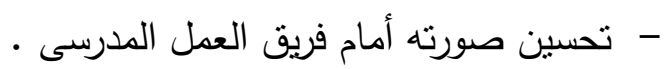

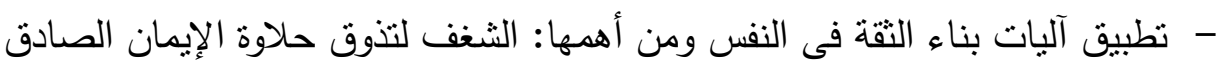

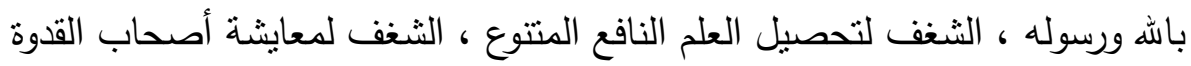
الصالحة ومدارسة سير حياة الناجحين، والرغبة والعزيمة فى تحقيق النجاح.

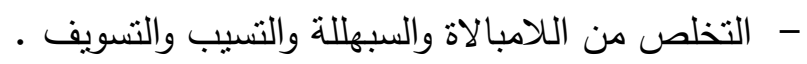
- تحرى الصدق فى الأقوال والأفعال مع فريق العمل المدرسى. 
- تحفيز فريق العمل بشتى سبل التحفيز المختلفة( المادية - المعنوية ) . - مالتخلص من المشاعر السلبية الهدامه التى تؤثز على مستوى الأداء. - تجنب لوم فريق العمل المدرسى على أتفه الأسباب. تونئ.

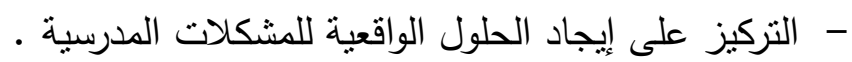

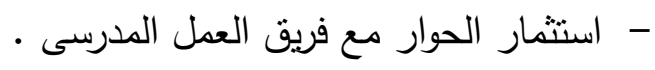
- اقتتاص المساهمات الإيجابية لفريق العمل المدرسى وتتميتها. - التخلص من مشاعر الكره التى تسيطر عليه تجاه فريق العمل المدرسى. - تعرف من يحبه ومن يكرهه داخل المدرسة.

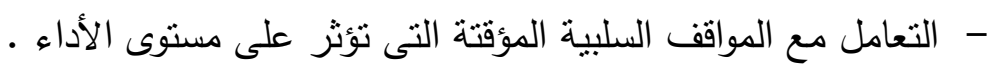

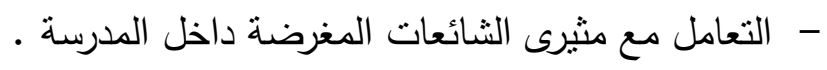
- الانصات الجيد لفريق العمل المدرسى. - تجنب المشكين فى جهود تحسين مستوى الأداء العام للمدرسة .

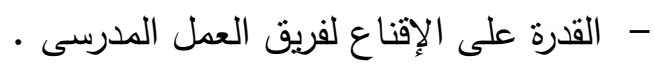

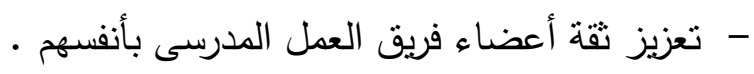
- تتمية شخصية المعلمين وتمكينهم من حل مشكلاتهم بطرق واقعية.

ثانياً: إظهار مدير المدرسة للحب الصادق لفريق العمل المدرسى: حيث تمثل عملية إضهار الحب لفريق العمل المدرسى من أهم المداخل والأساليب لتعريف فريق العمل المدرسى بأن المبل

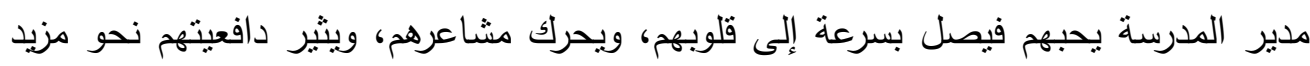

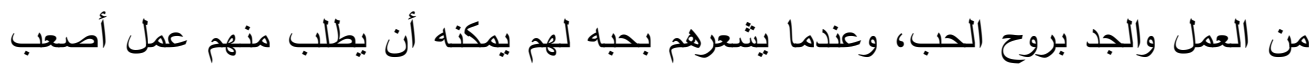

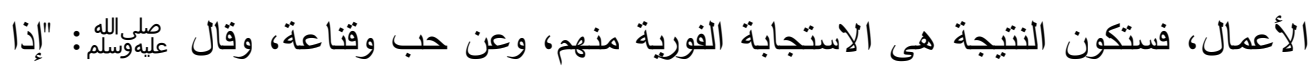

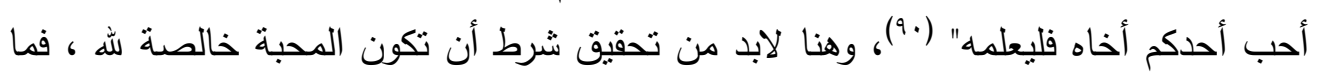

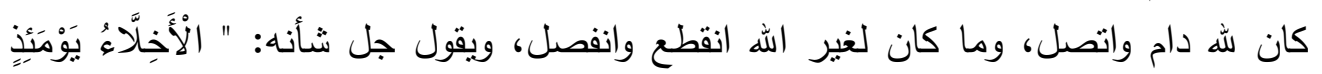

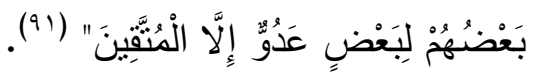

ثالثاً: ممارسة مدير المدرسة لروح الدعابة البناءة مع فريق العمل المدرسى: الدعابة

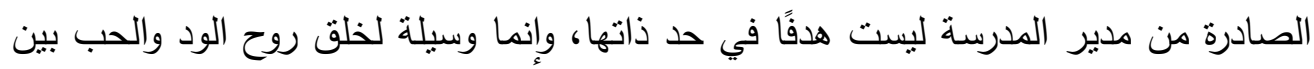

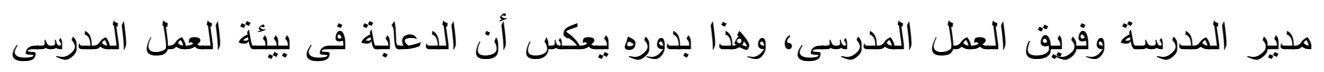

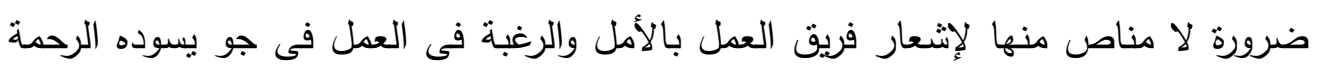

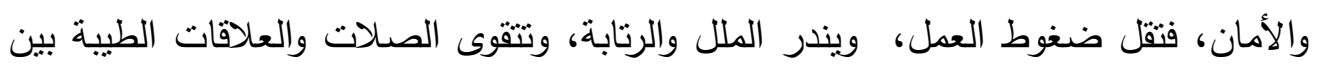
الجميع، وما أمس الحاجة للاعابة البناءة فى الددارس. 
رابعاً: يكون مدير المدرسة قيادياً فى إدارته: بعتبر مدير المدرسة المثل الأعلى والقدوة لفريق

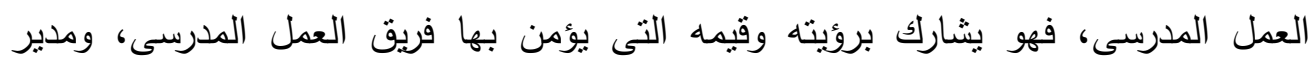

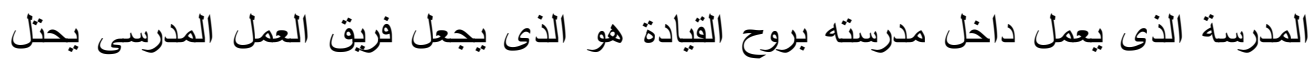

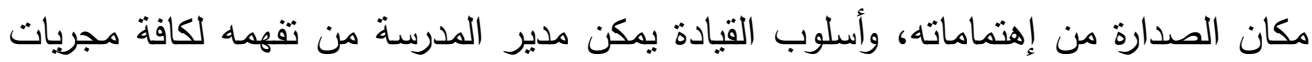

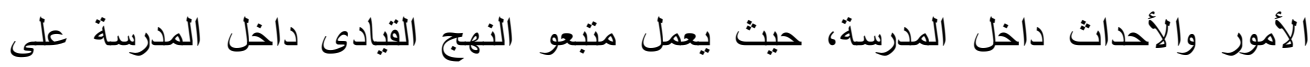
تحميس فريق العمل المدرسى وتحسين روحهم المعنوية من خلال دورهم فى صناعة الإيجابية

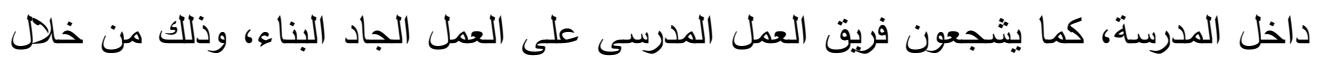

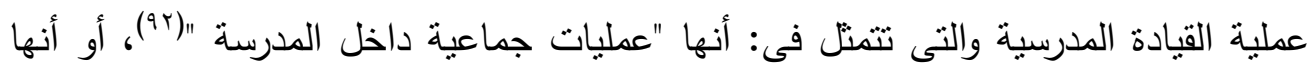

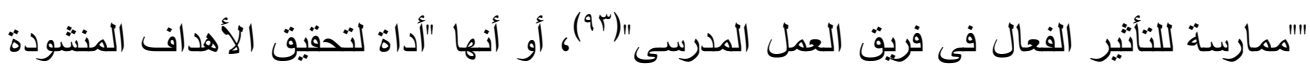

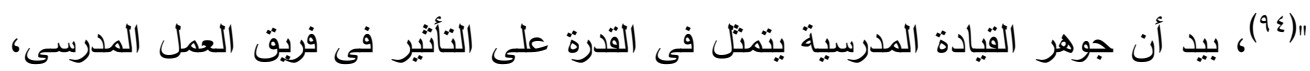

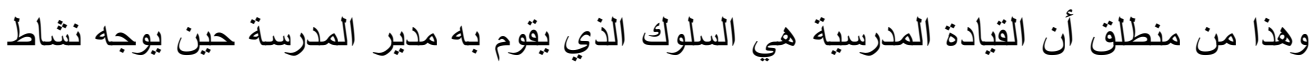
فريق العمل المدرسى نحو هدف مشترك ينبخى على الجميع تحقيقه، والقيادة المدرسية الفعالة

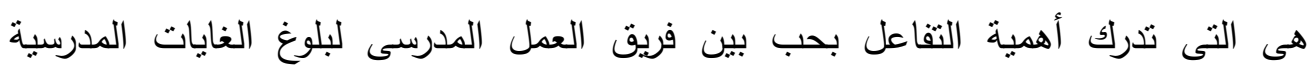

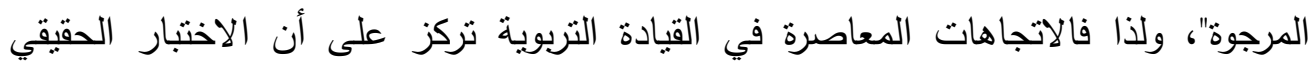

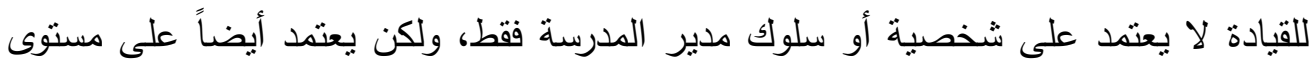

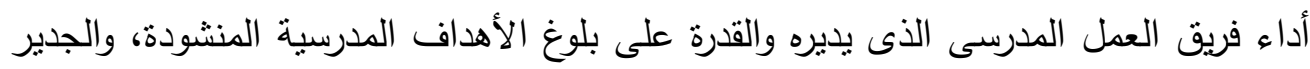

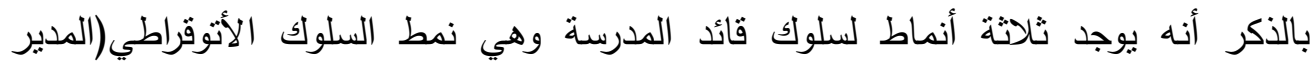

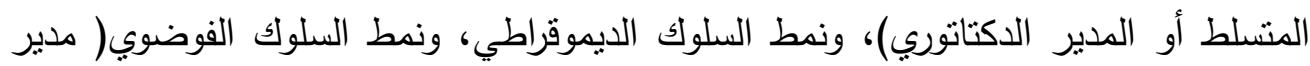

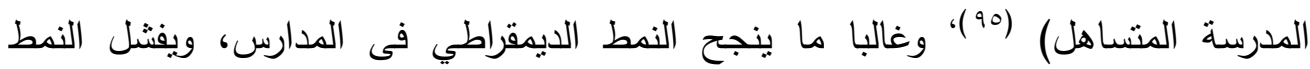

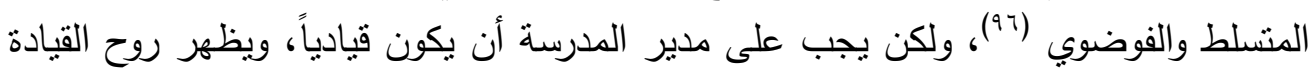

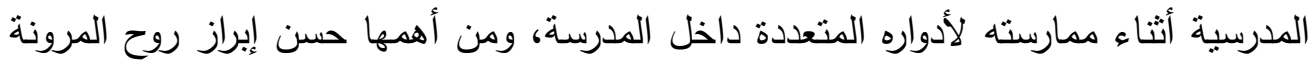

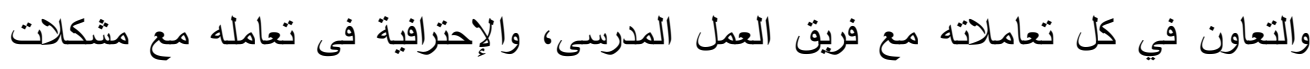
معلميه وتلاميذه، وحسن توفير مناخ مدرسى ديمقراطى يسوده الود والحب بين دين الجميع.

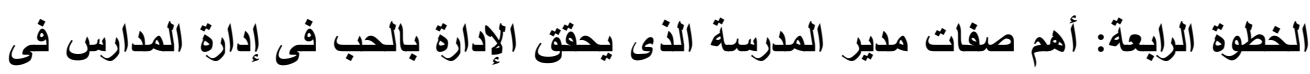

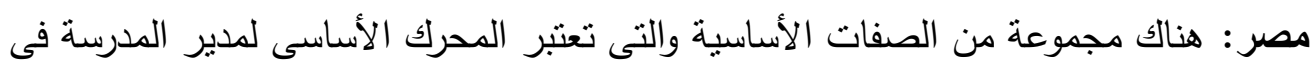

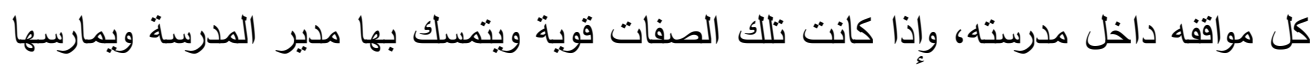
على أرض الواقع داخل مدرسته فسوف يؤدى ذللك إلى تحقيق الإدارة بالحب فئل في إدارة

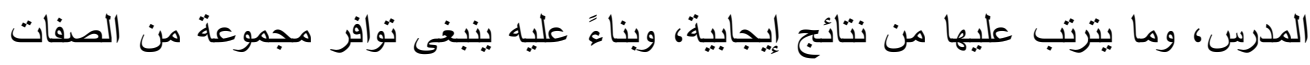
فى مدير المدرسة، ومن أهمها : 


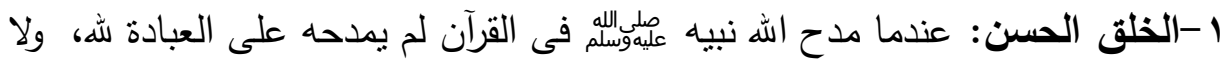

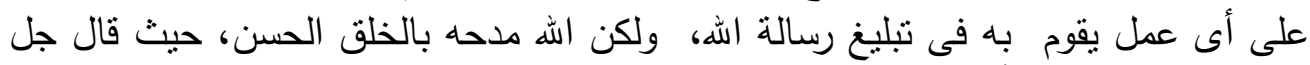

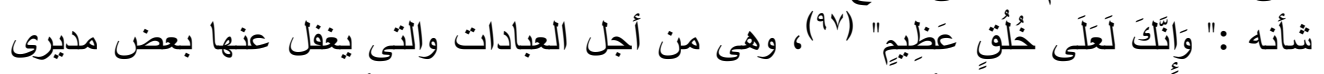

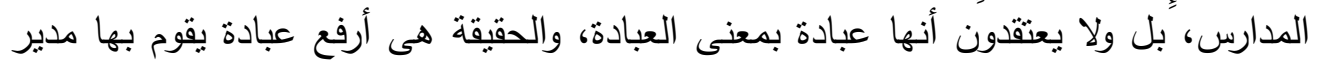

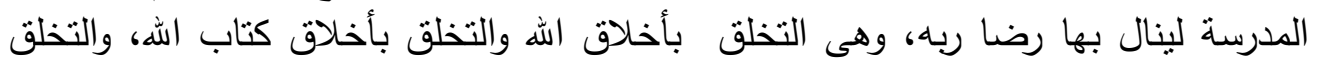

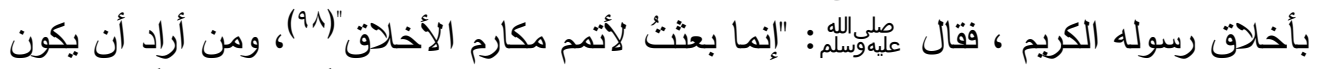

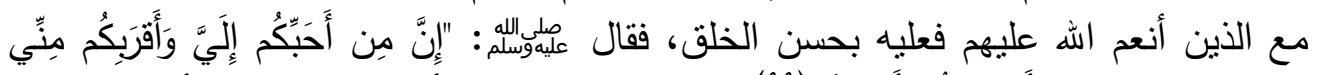

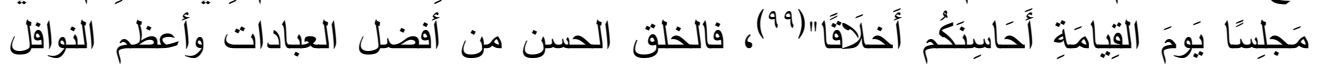

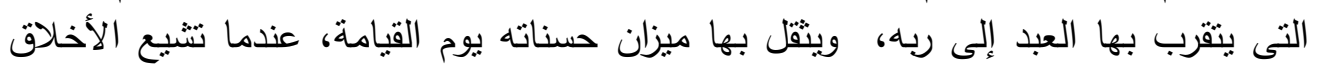

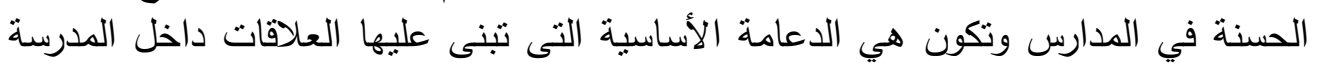

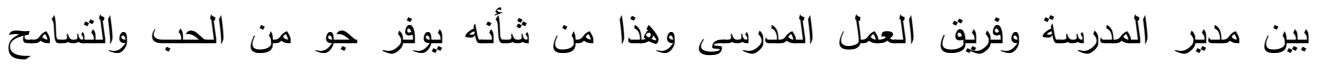

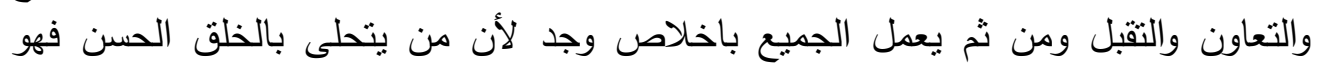

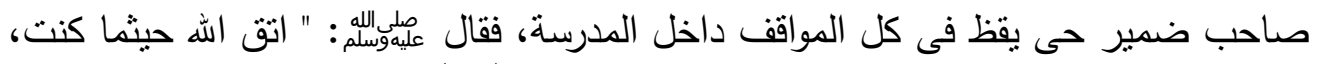

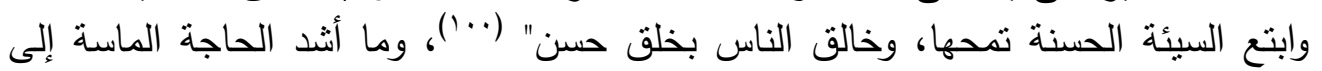

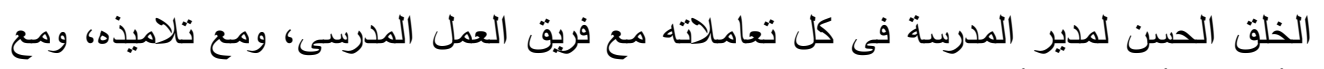

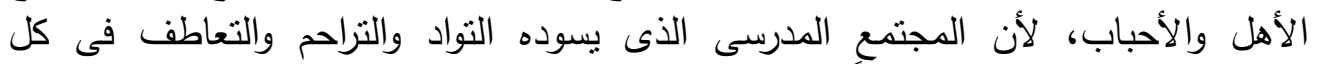

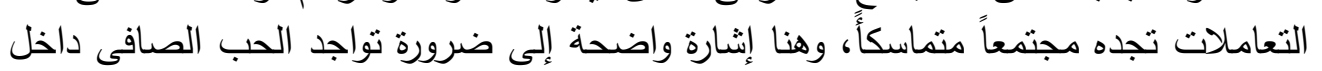

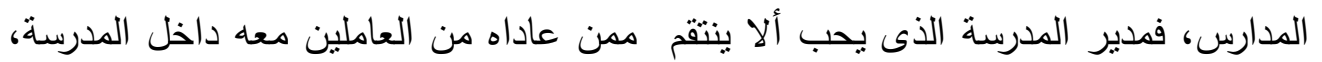

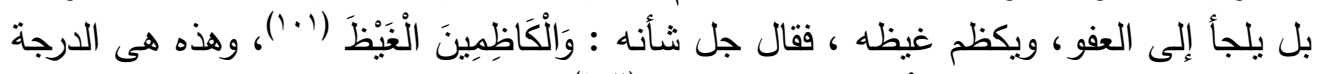

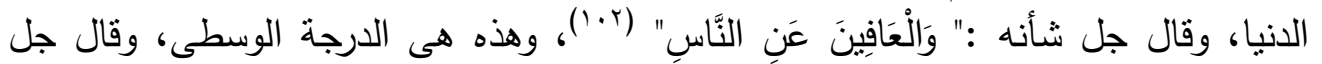

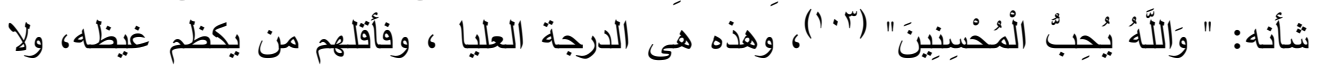

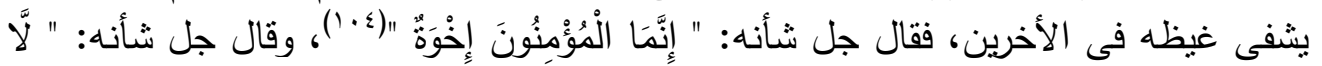

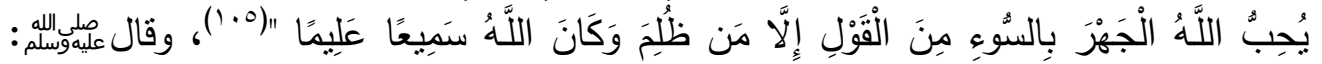

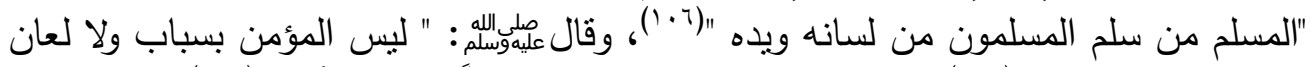

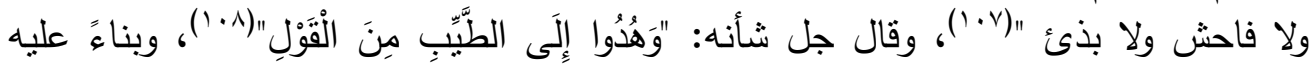

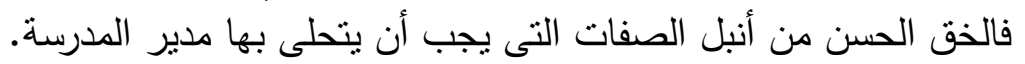

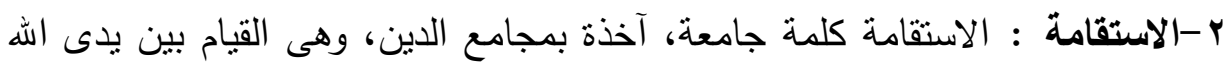

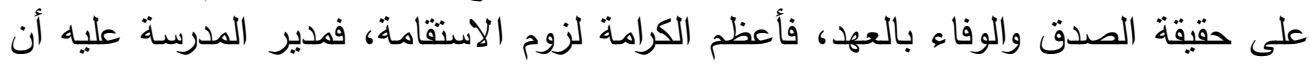

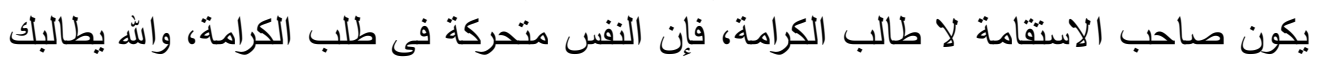

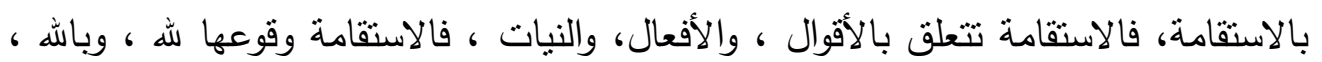

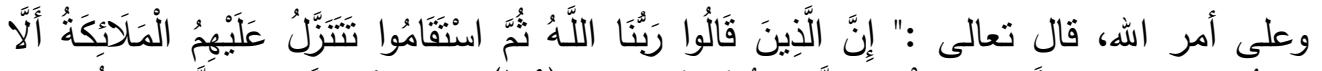

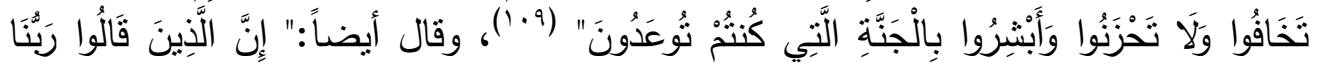

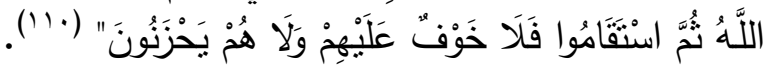




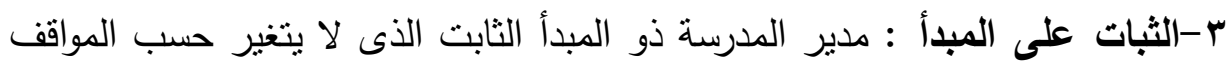
التى تقابله داخل المدرسة، هو المدير الذى بحيا فى سبيل إعلاء هذا المبدأ ، فقال جل شأنه التها

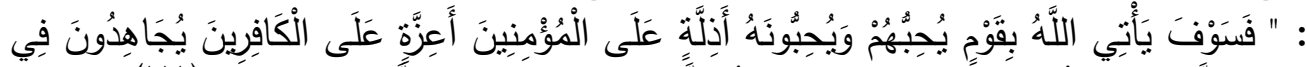

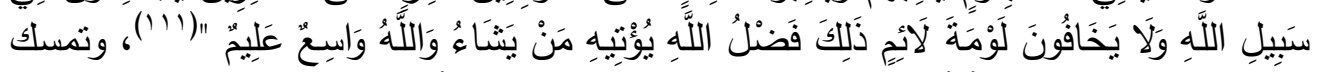

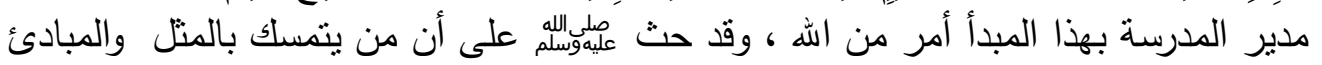

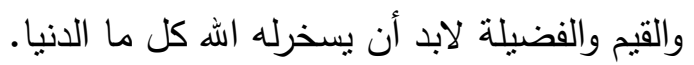

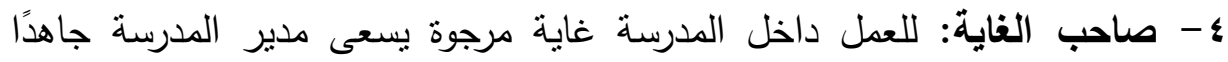

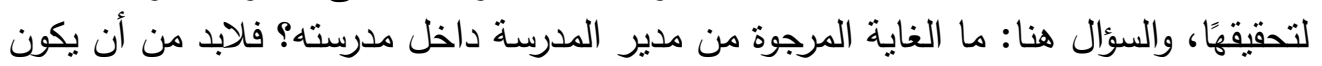

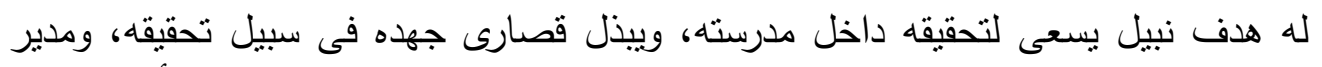

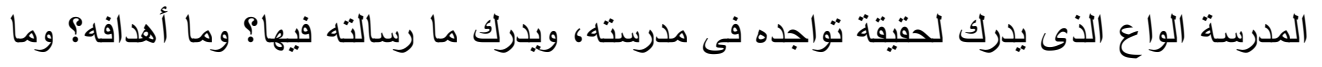

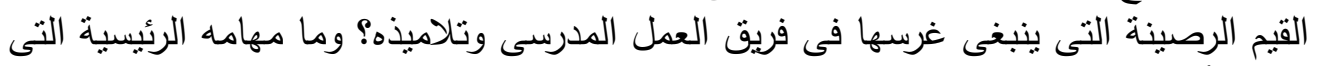

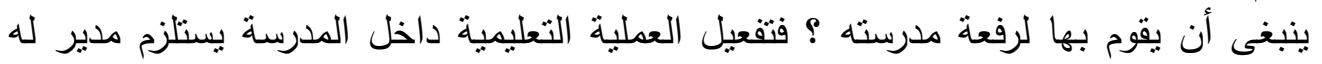
غاية واضحة داخل مدرسته.

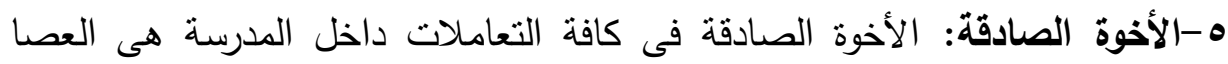

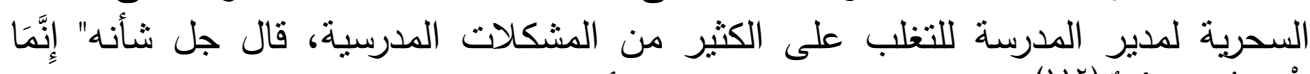

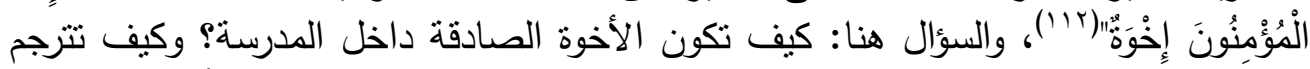

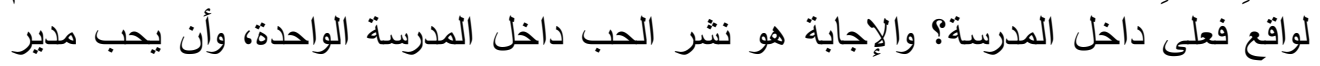

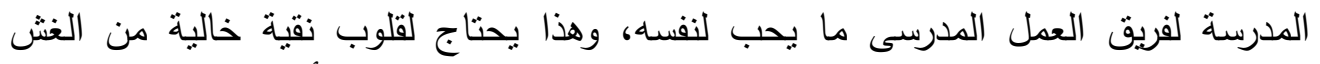

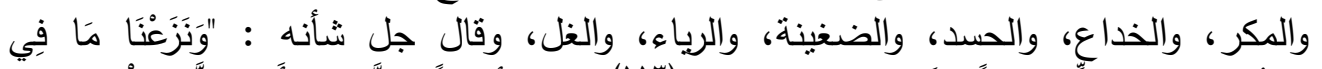

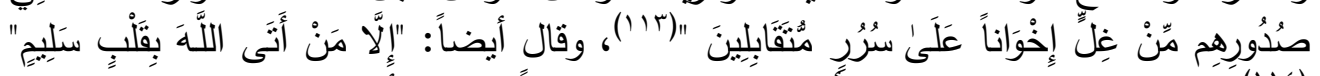

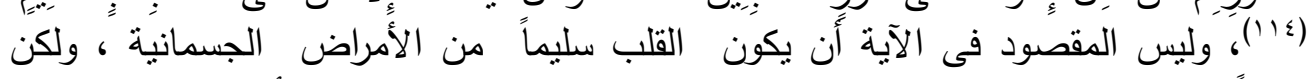

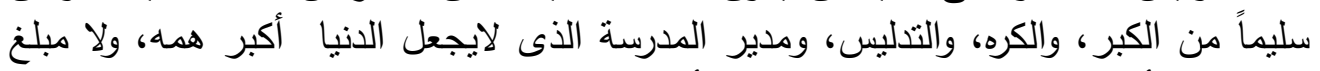

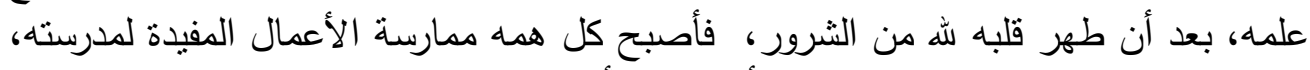

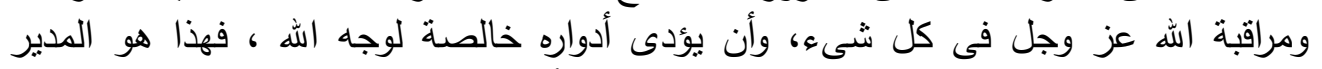

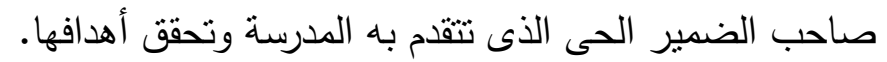

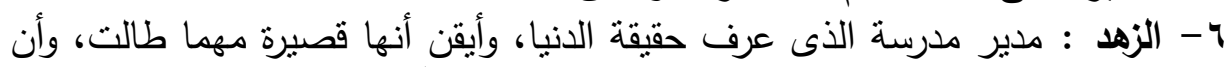

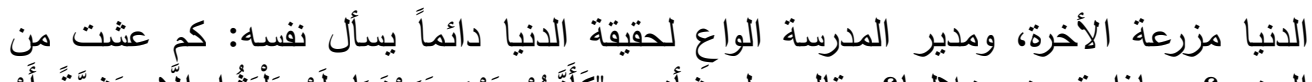

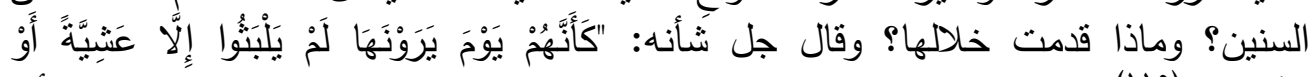

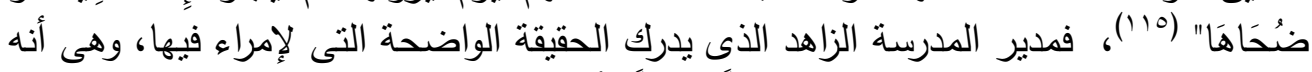

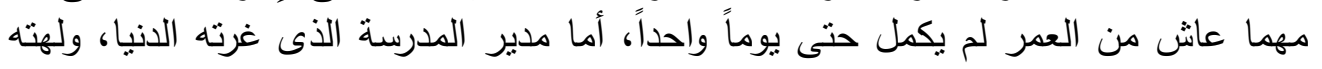

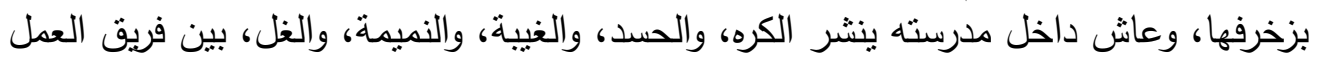

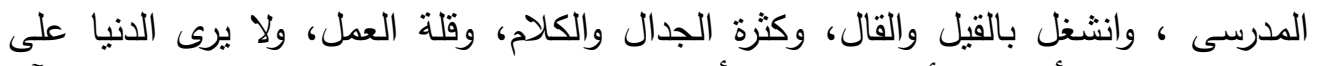

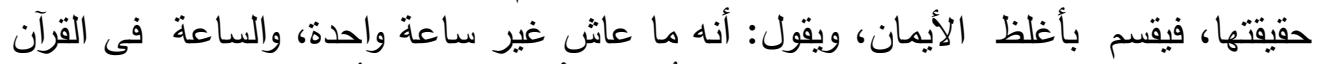

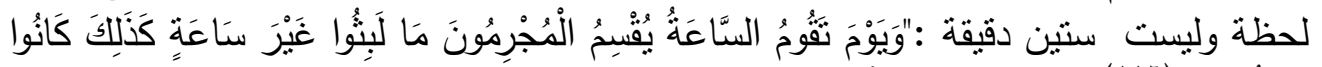

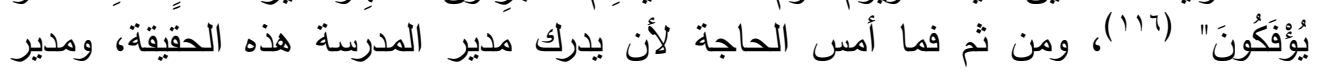




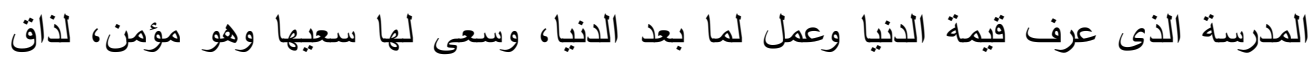

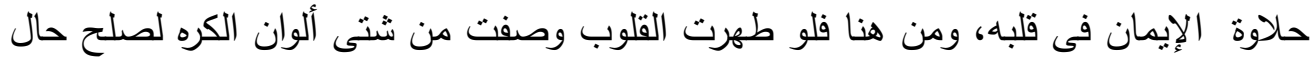

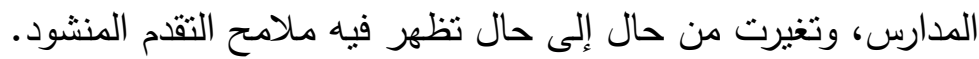

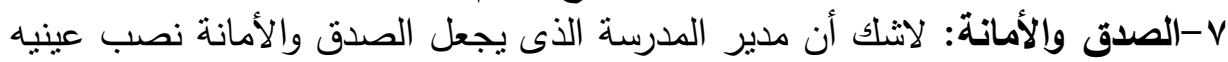

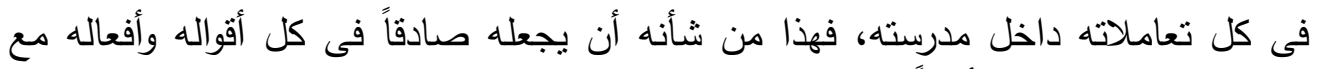

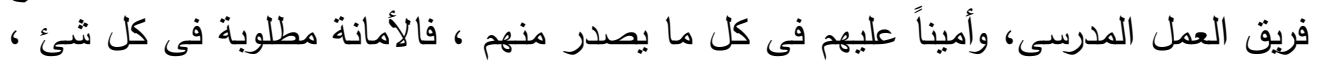

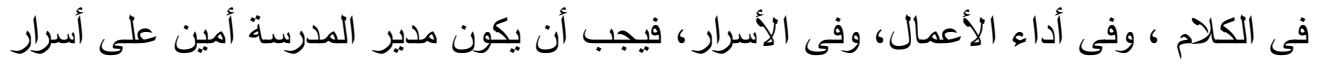

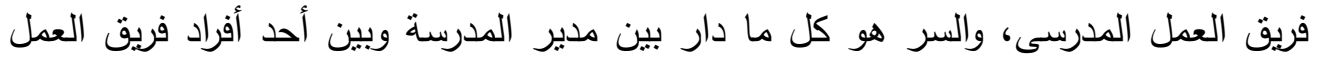

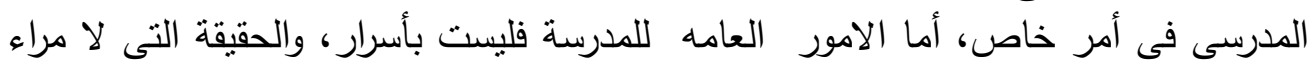

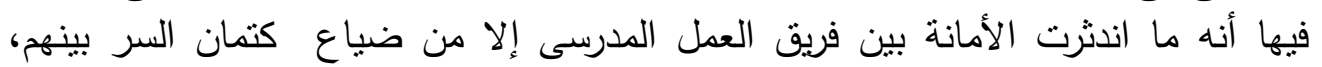

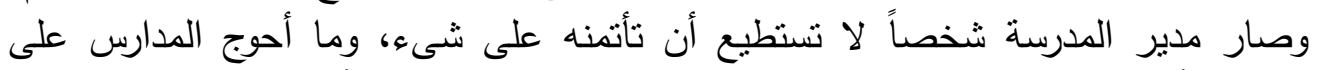

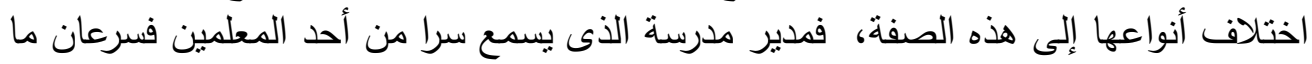

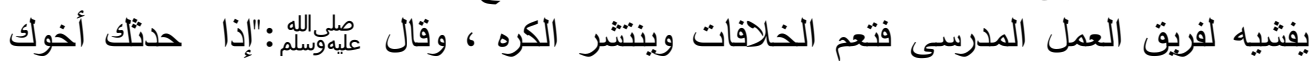

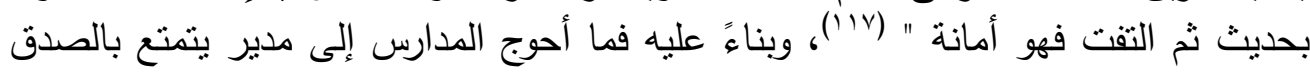

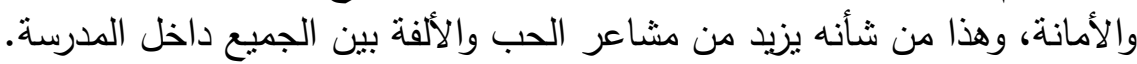

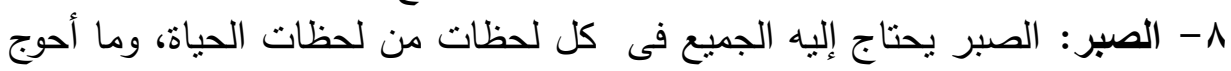

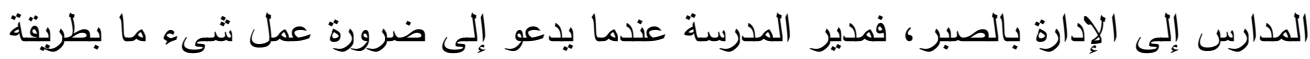

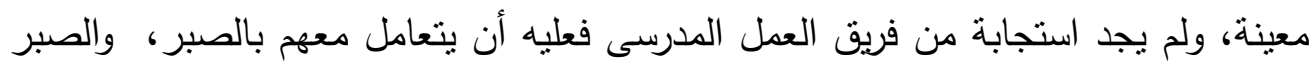

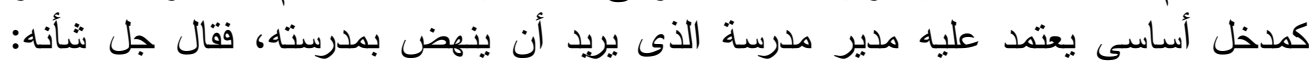

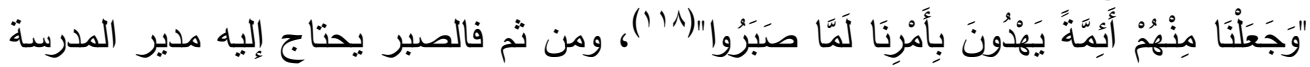

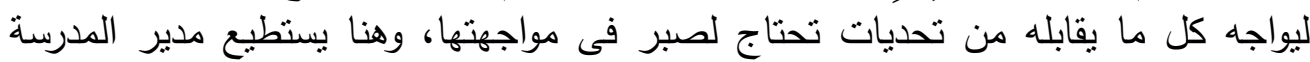

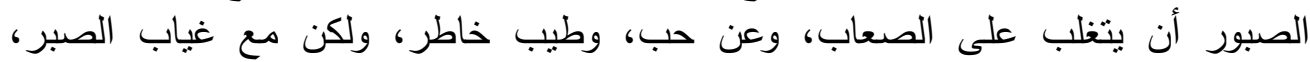

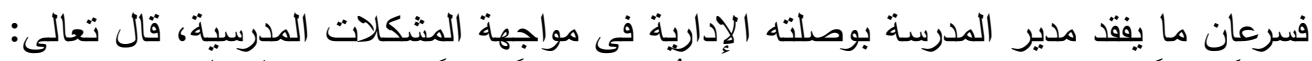

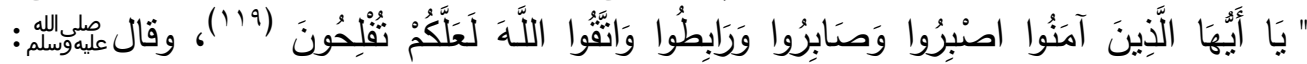

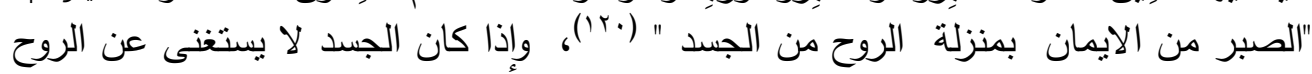

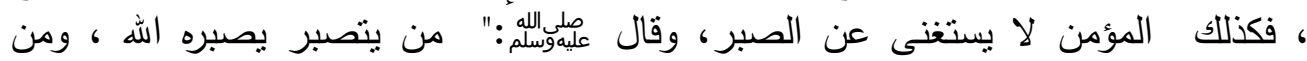

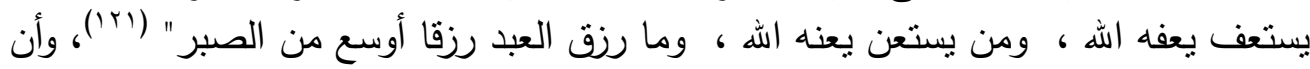

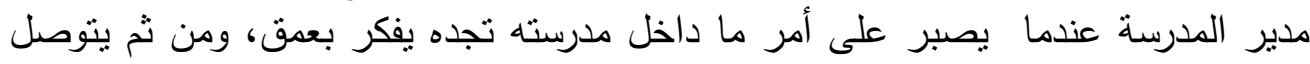

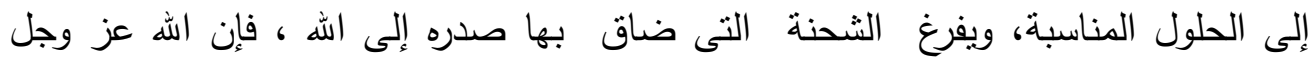

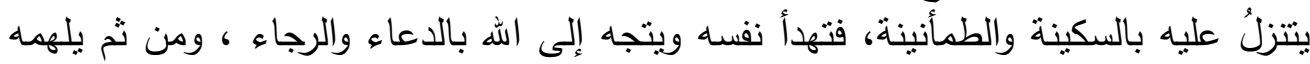

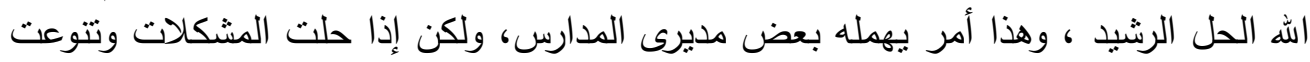

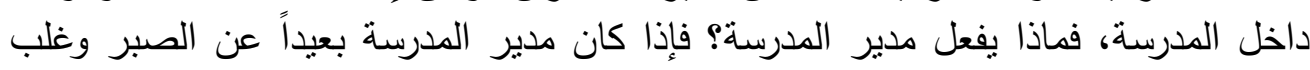

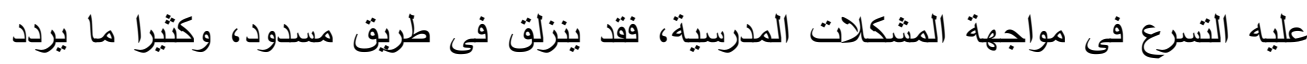

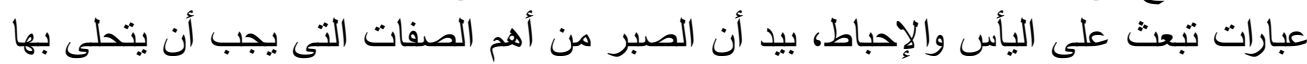




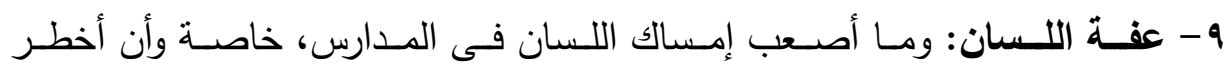

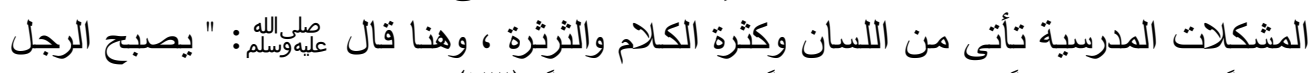

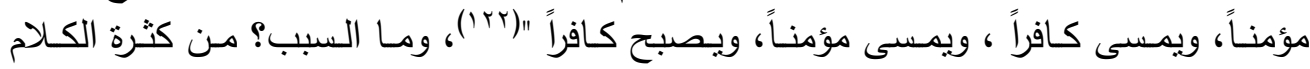

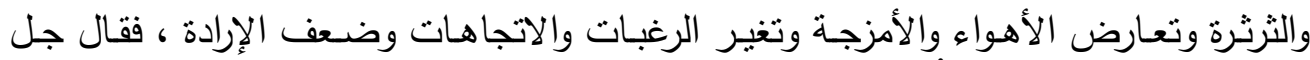

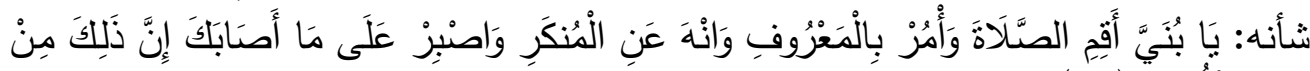

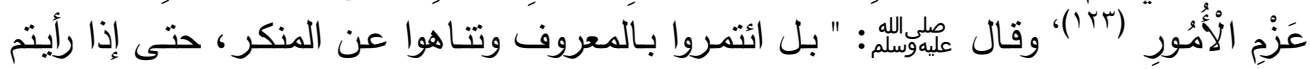

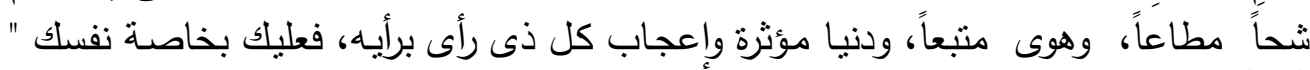

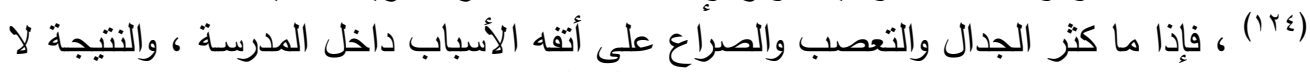

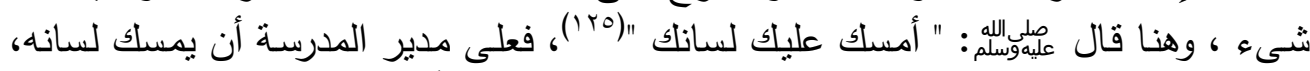

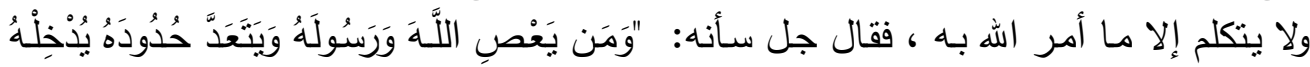

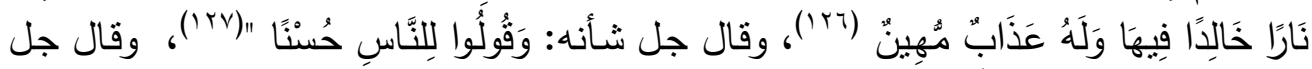

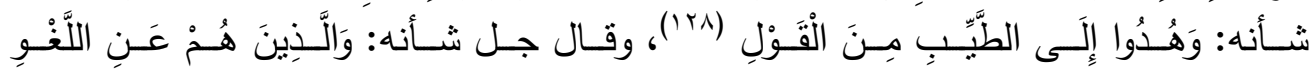

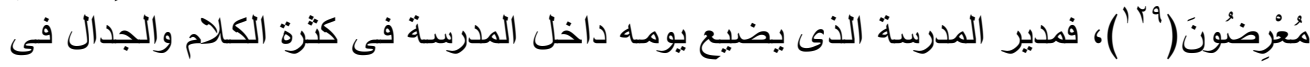

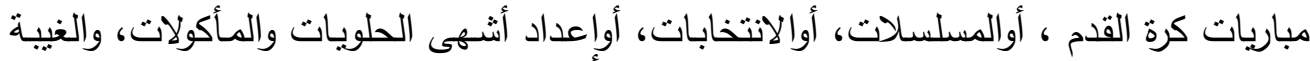

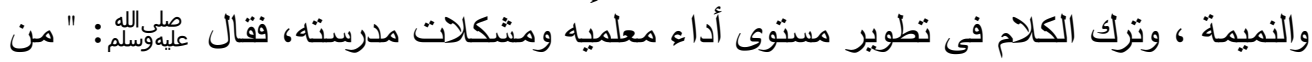

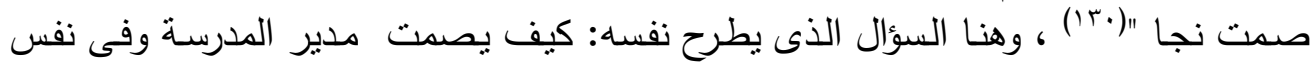

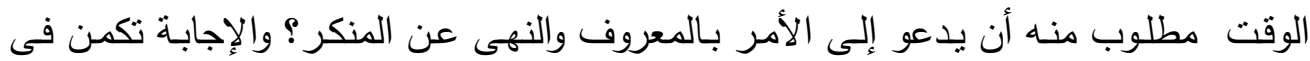

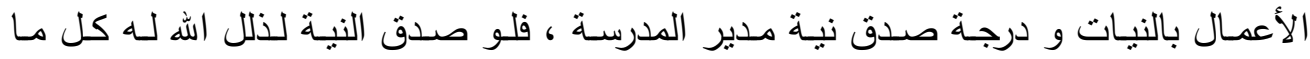

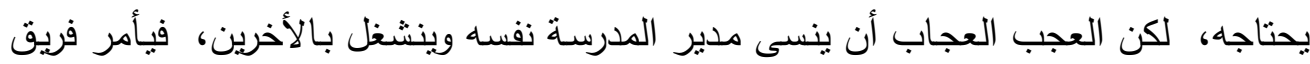

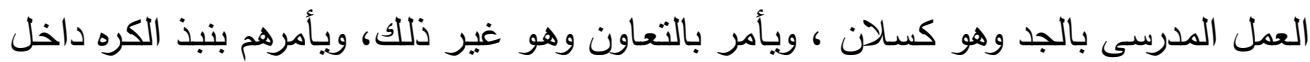

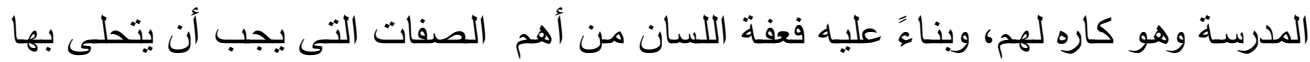
مدير المدرسة، وأن يمسك لسانه عن وناء عليه اللغو والقيل والقال.

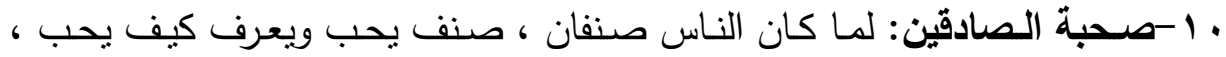

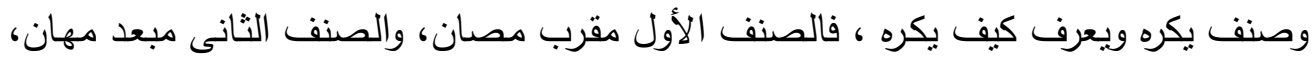

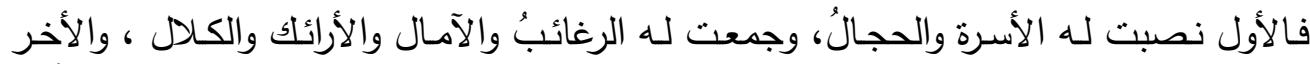

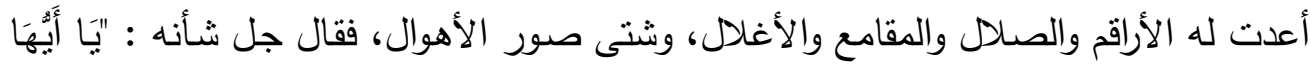

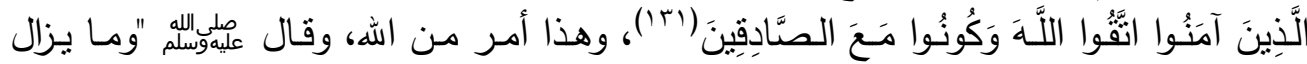

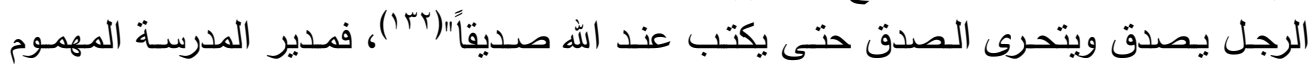

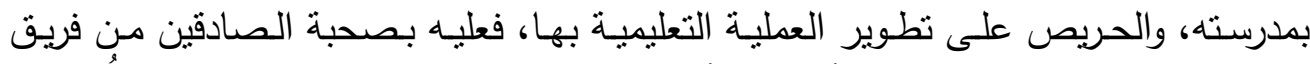

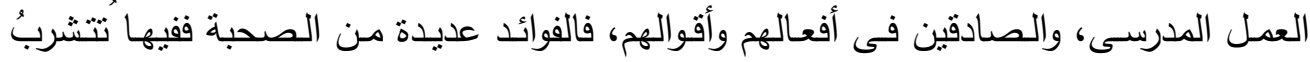

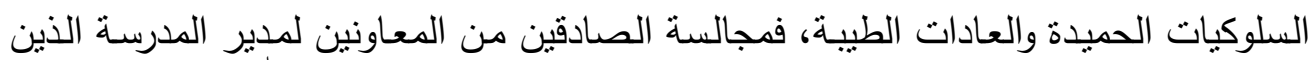

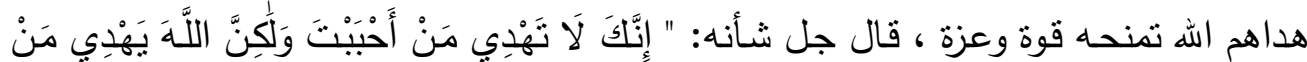

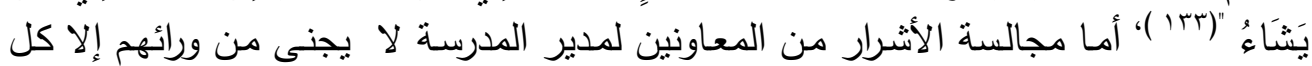

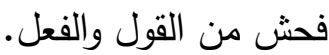


1 الا - مراقبة لله عز وجل: مدير المدرسة عليه مراقبة الله فى كل تصرفاته، ويعي جيداً

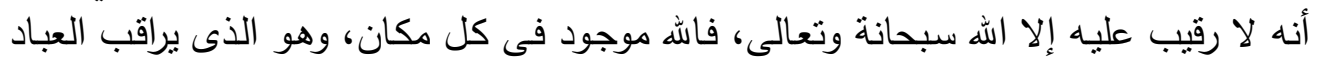

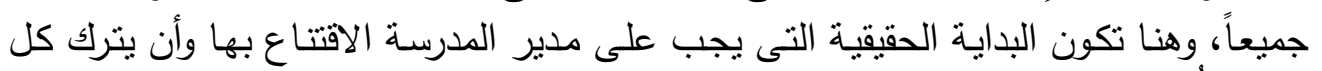

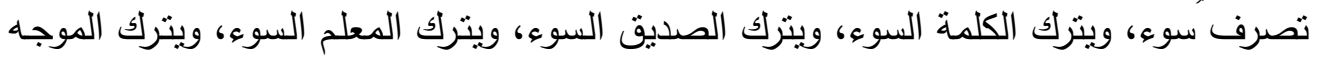

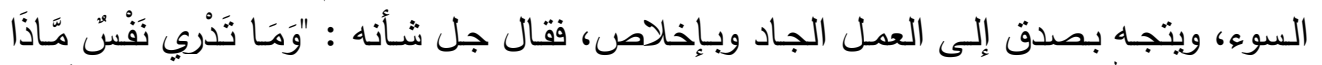

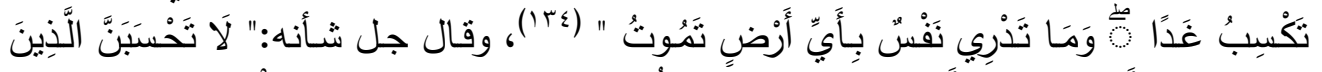

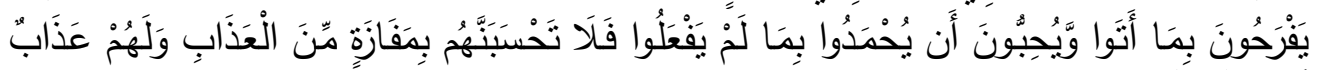

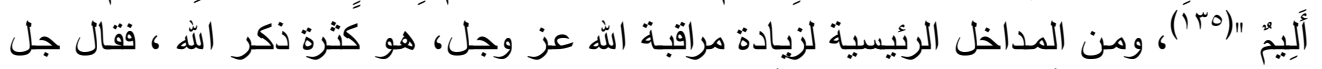

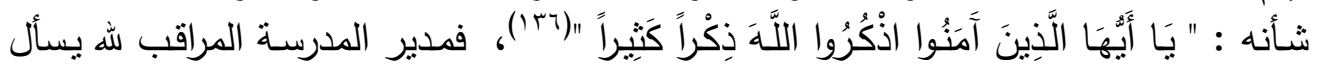

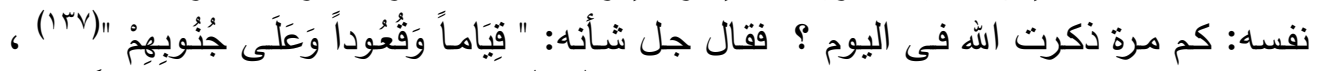

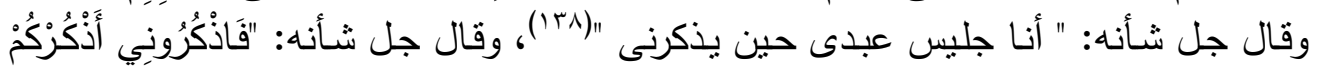

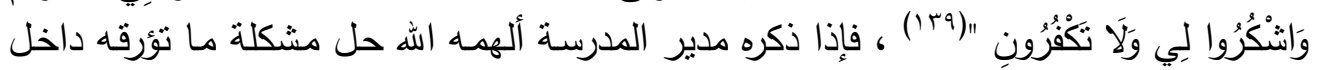

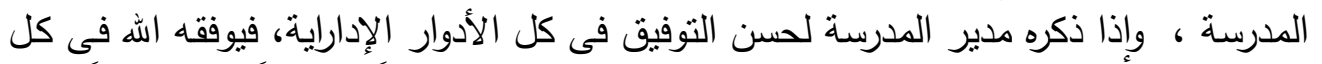

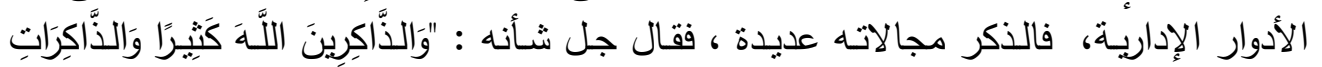

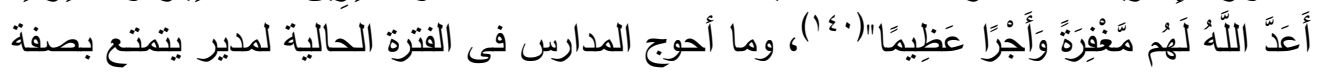

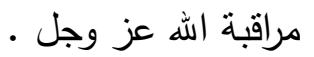

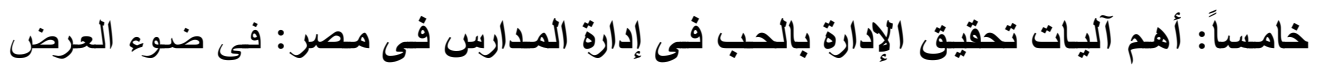

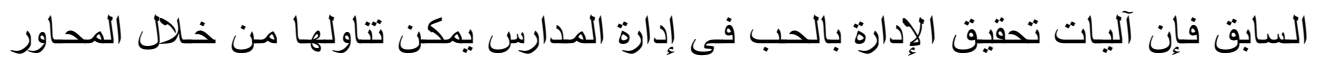
التالية:

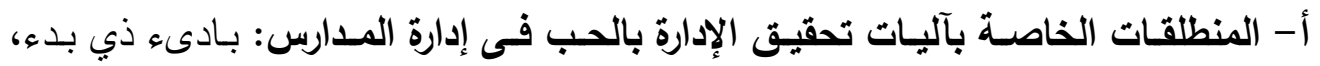

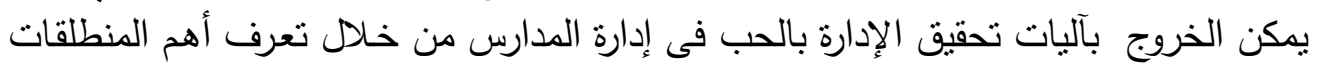

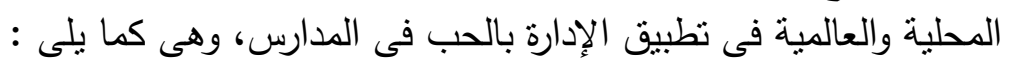

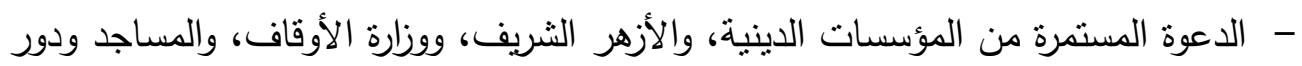

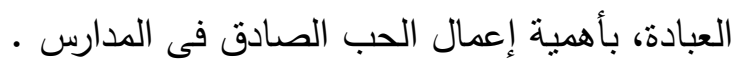

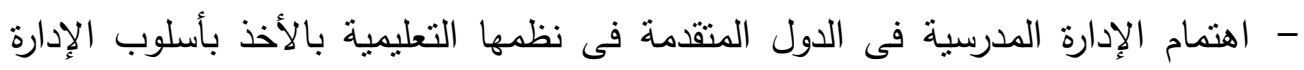

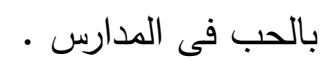
- ظهور بعض القيم السلبية التى كثرت، واستترت، وانتشرت، والتى تعكس درجات متفاوتة

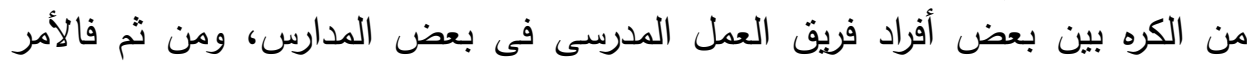

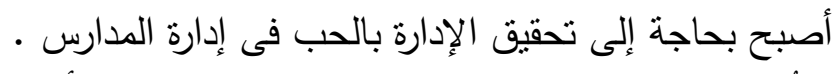

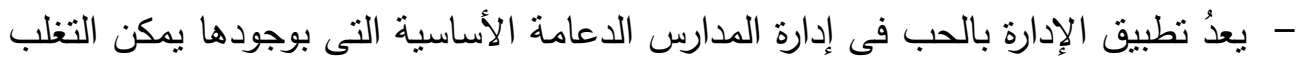

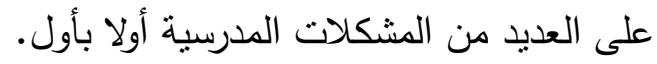

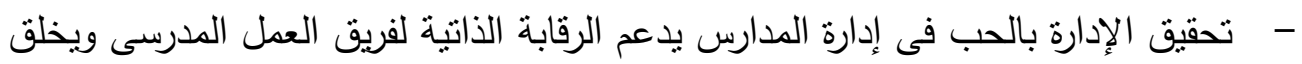
روح الالتزام الوظيفى لديه. 
- تحقيق الإدارة بالحب فى إدارة الددارس بضفى مزيدا من التفانى والإخلاص فى أداء

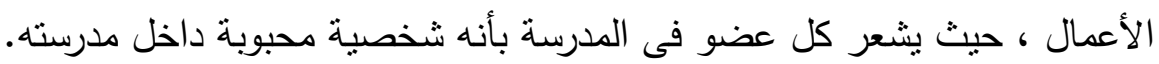

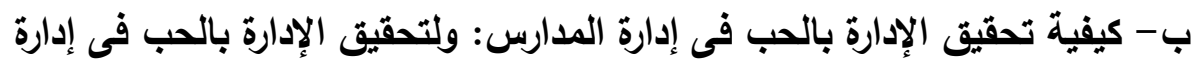

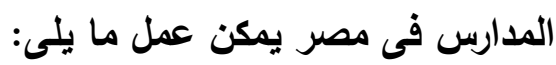

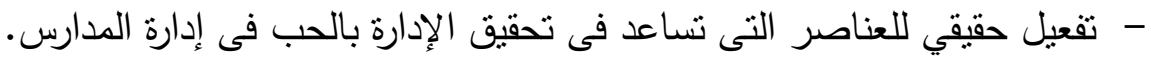
- - تدعيم العلاقات الإنسانية الطيبة داخل المدارس.

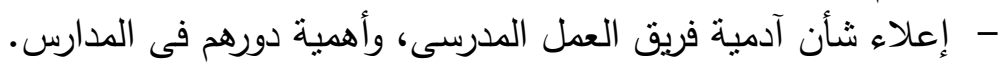

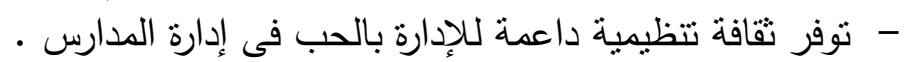

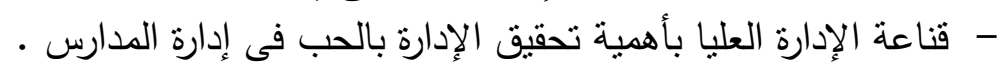

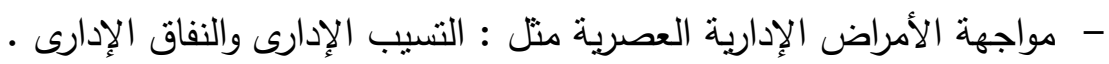

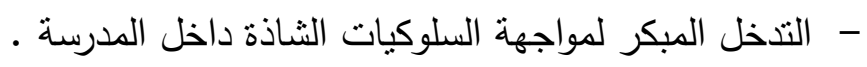

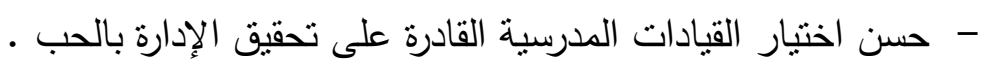

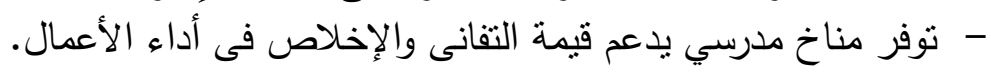

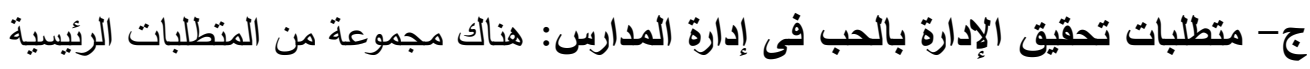

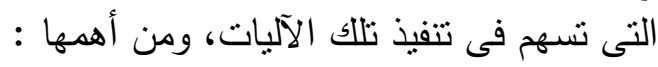

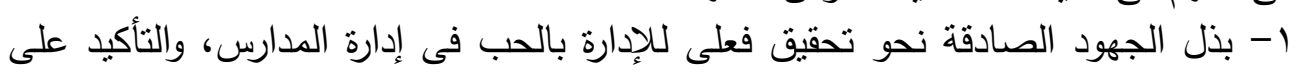

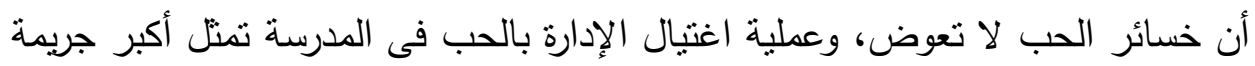

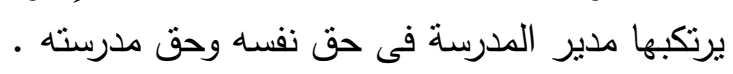

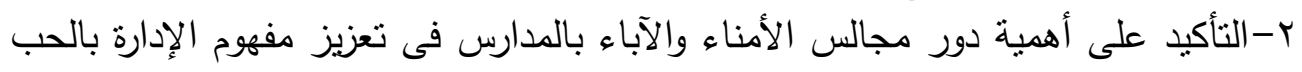

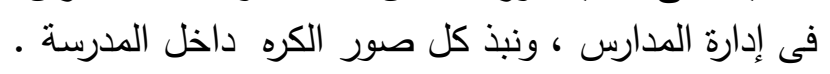

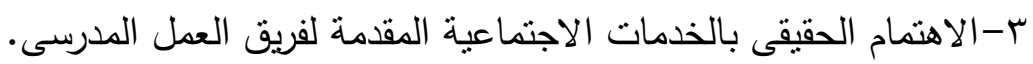

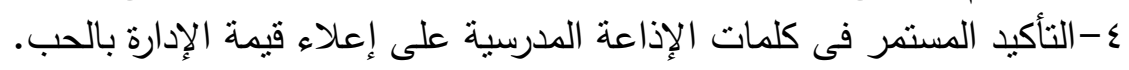

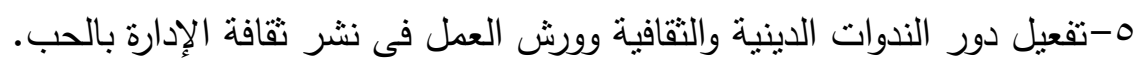

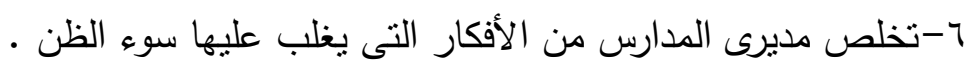

V- V- Vلص مديرى المدارس من أسلوب الرقابة البوليسية وتصيد أخطاء المعلمين.

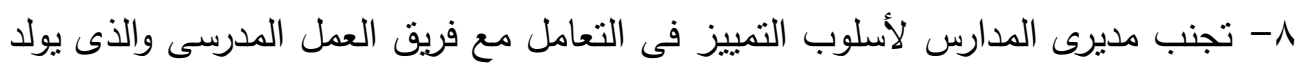

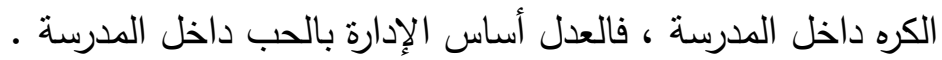

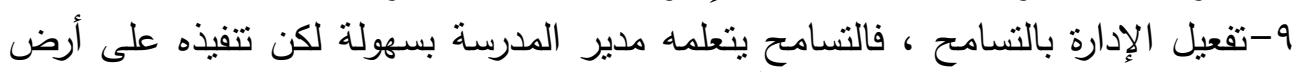

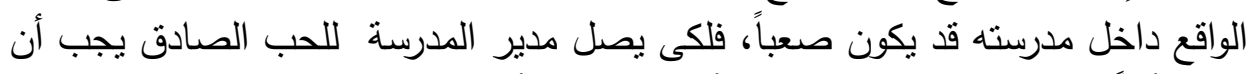

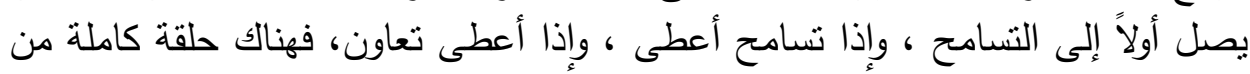

$$
\text { ( التسامح - الحب - العطاء- التعاون ). }
$$


• 1- ضرورة تدريب مدير المدرسة على فنيات التسامح، والتأكيد على التسامح الذاتى،

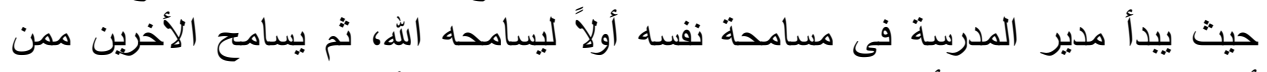

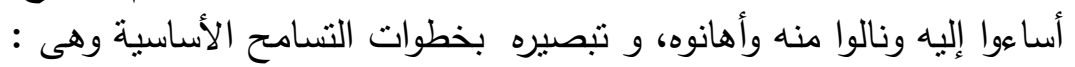

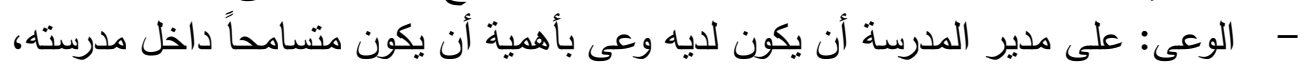

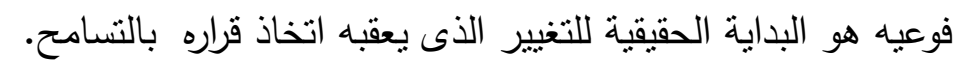

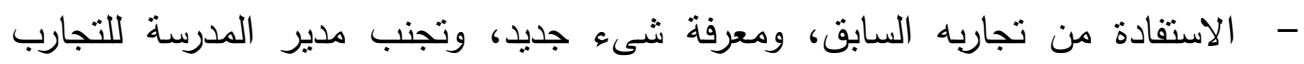

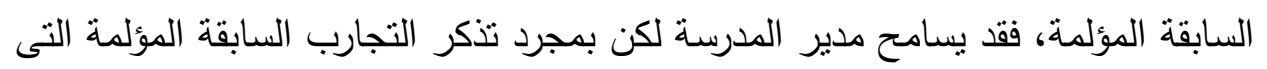

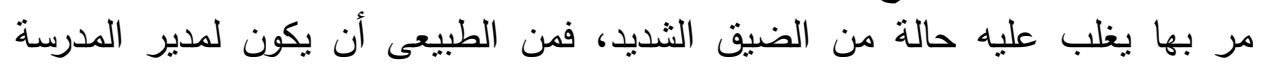

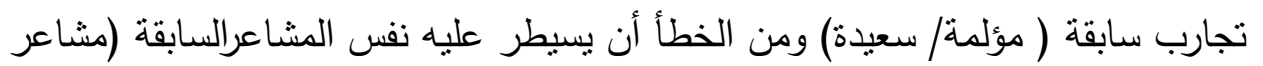

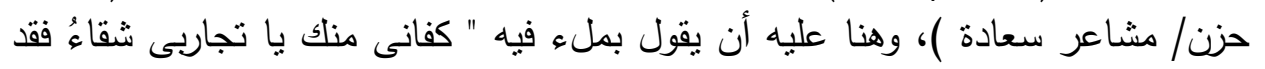

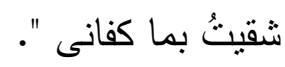

- - التخلص من كل النظرات السلبية ، والعمل بطريقة يغلب عليها روح الإيجابية.

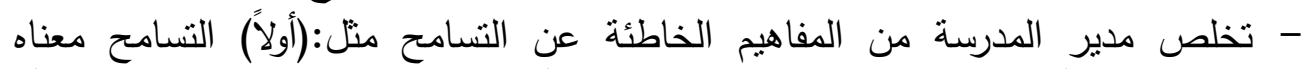

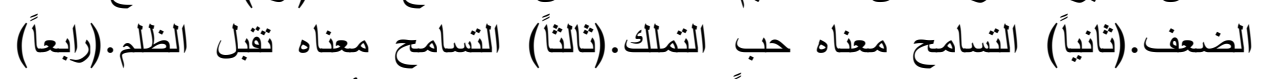

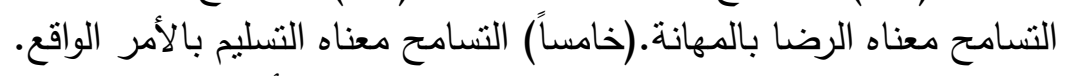

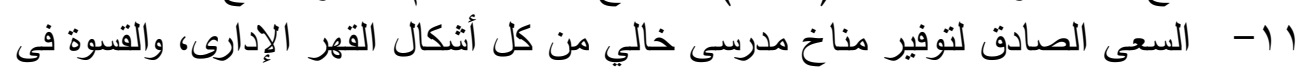

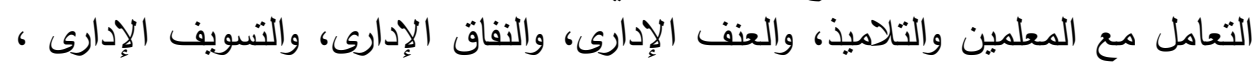
وخلافات العمل، والصراعات المستمرة داخل المدرسة.

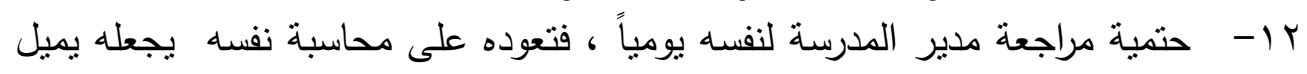

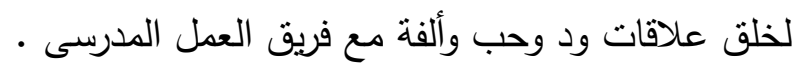

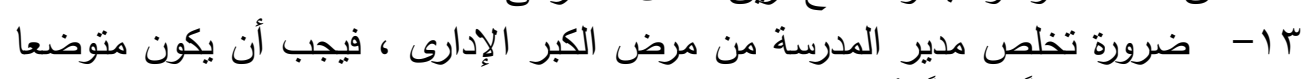

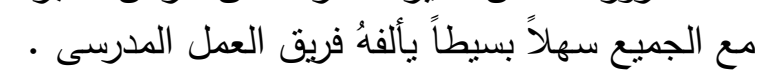

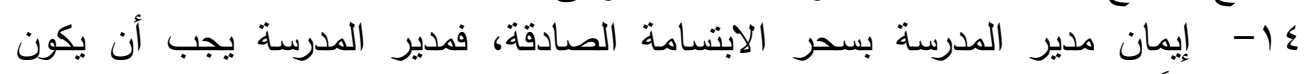

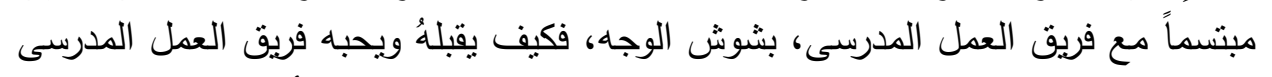

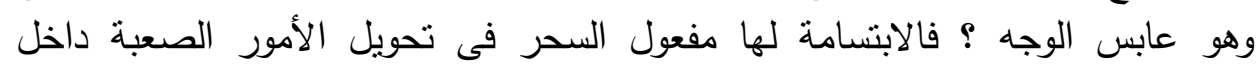

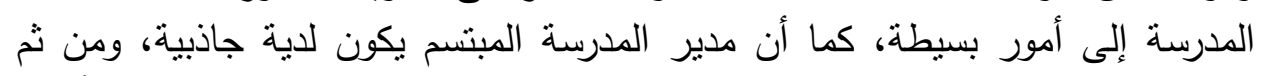

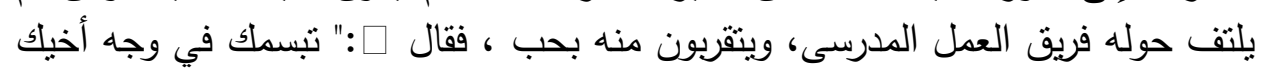

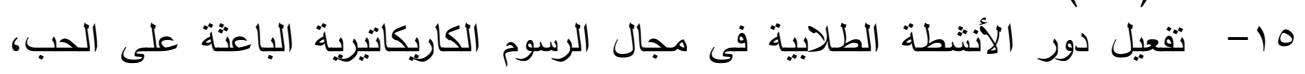

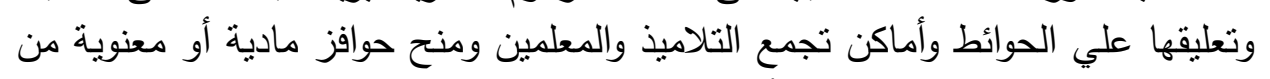

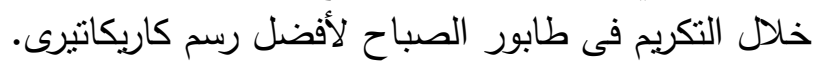

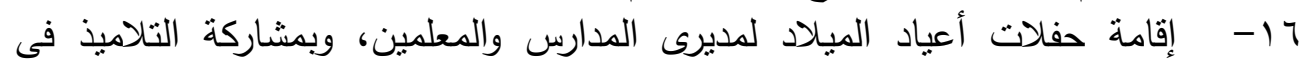

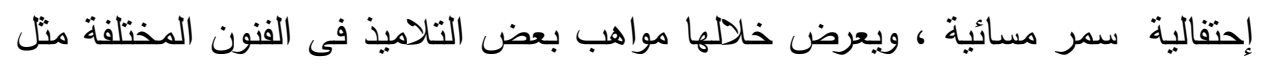
تقليد الفنانين، والثعر ، والفوازير ، والتمثيل. 


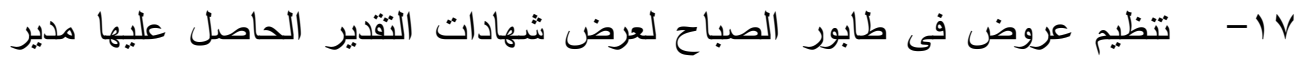

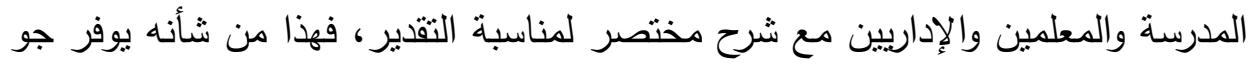

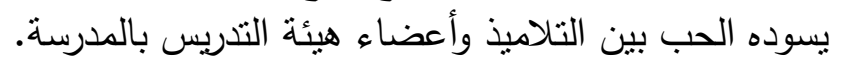

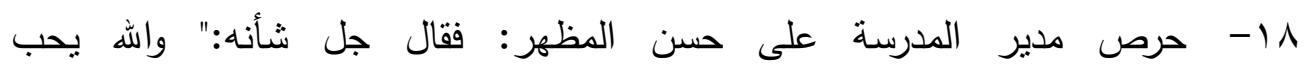

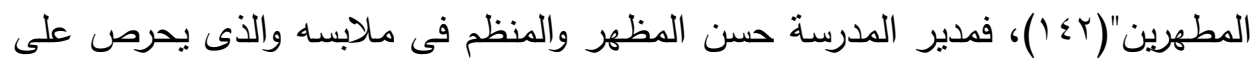

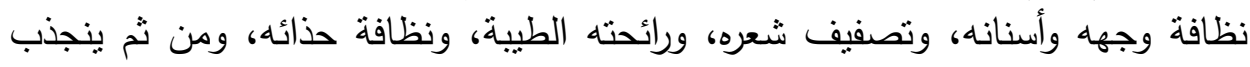

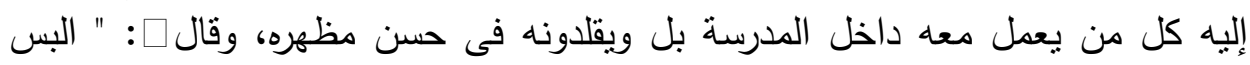

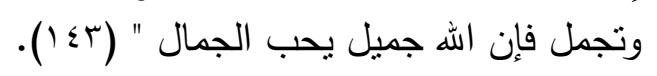

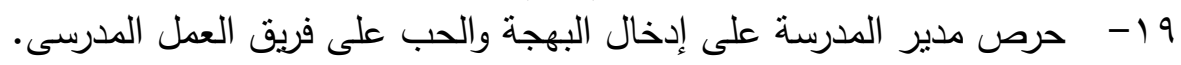

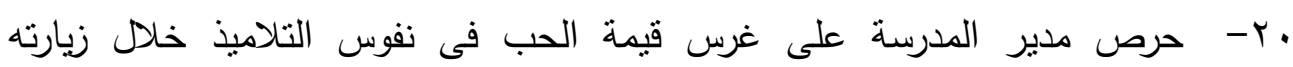

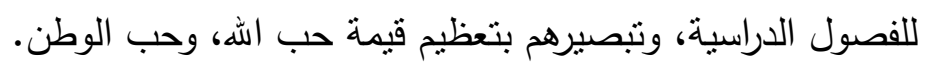

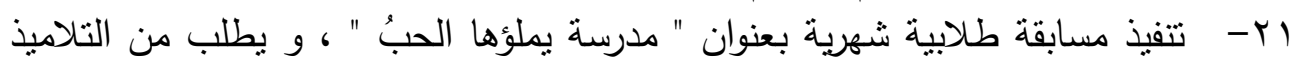

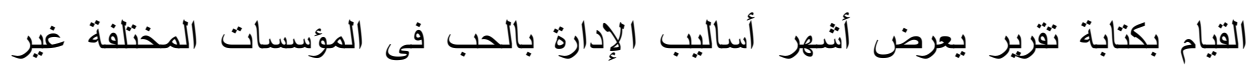

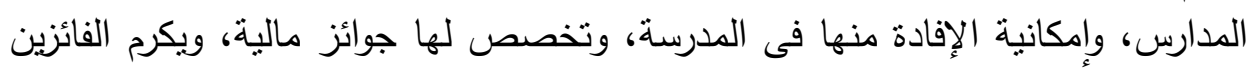

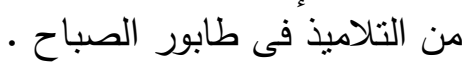

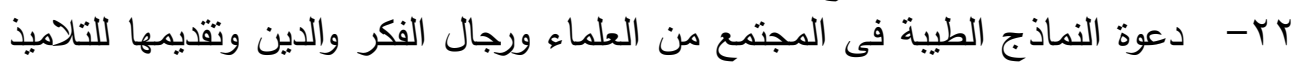

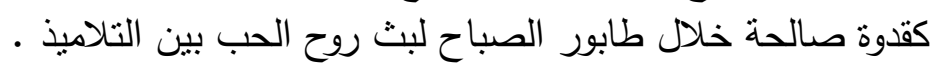

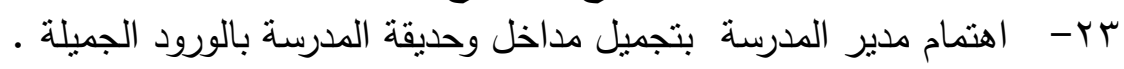

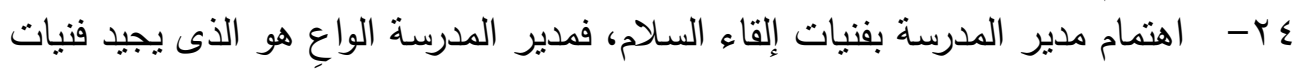

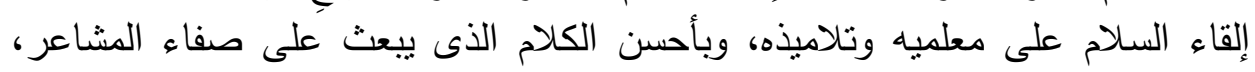

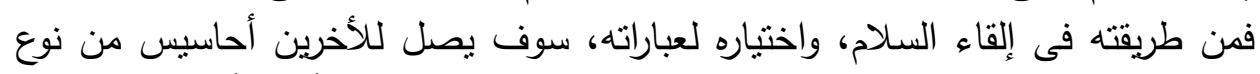

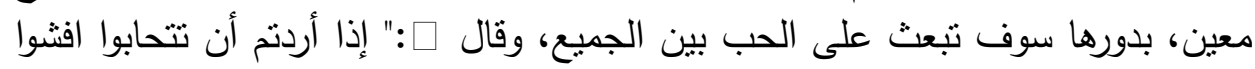

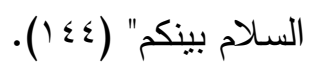

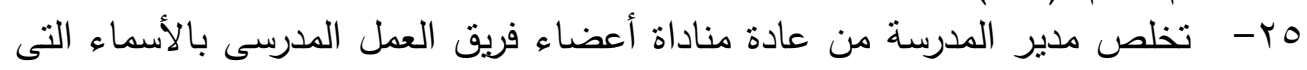

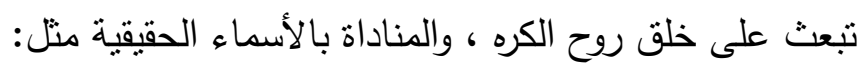

جدول (9) يبين المناداة بالأسماء غيرالمرغوية والأسماء الحقيقية

\begin{tabular}{|c|c|c|}
\hline الأسماء الحقيقية & الأسماء غير المر غوبة & م \\
\hline الأستاذ زكريا & الأستاذ "زيكو " & 1 \\
\hline الأستاذ حسين & الأستاذ " سحس " & $r$ \\
\hline الأستاذ مرجان & الأستاذ " "مرج" & $\mu$ \\
\hline الأستاذ ممدوح & الأستاذ " "دوحة " & $\varepsilon$ \\
\hline الأستاذة نجيبة & الأستاذة " "نوجة " & 0 \\
\hline الأستاذة أفراح & الأستاذة " أحزان " & 7 \\
\hline الأستاذة شريفة & الأستاذة " خيانة " & $\mathrm{V}$ \\
\hline
\end{tabular}




\section{- - المقترحات لبحوث مستقبلية : -}

يقترح الباحث من خلال هذه الدراسة القيام بالبحوث والدراسات التالية : 1-آليات تحقيق الإدارة بالحب فى إدارة مديريات التربية والتعليم فى مصر ( دراسة تحليلية). ץ-آليات تحقيق الإدارة بالحب فى إدارة المدارس الخاصة في في مصر ( دراسة تحليلية). r-آليات تحقيق الإدارة بالحب فى الإدارات التعليمية فى مصر ( دراسة تحليلية). ع-آليات تحقيق الإدارة بالحب فى إدارة التوجيه التربوى بالمديريات التعليمية فى مصر (دراسة تحليلية ).

ه-آليات تحقيق الإدارة بالحب فى إدارة كليات التربية فى مصر ( دراسة تحليلية ).

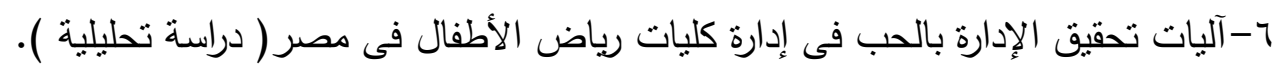

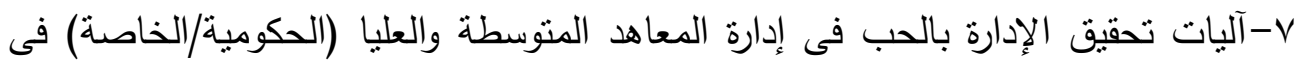
مصر (دراسة تحليلية). 


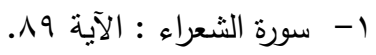

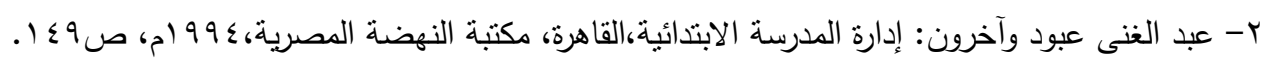

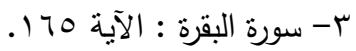

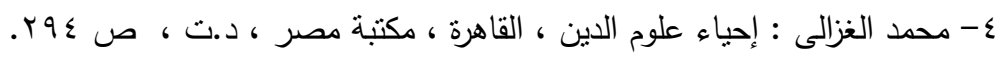

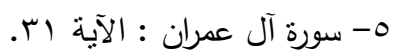

צ- رواة مسلم : حديث صحيح.

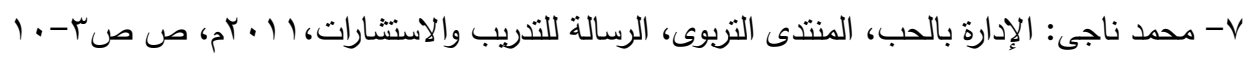

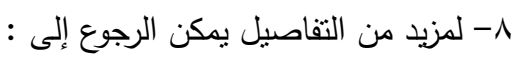

- Fredericks, Janet and Brown, Steven, School Effectiveness and Principal Productivity, N.A.S.S.P. Bulletin, Nov. 1993.

$$
\begin{aligned}
& \text { - محمد ناجى: الإدارة بالحب، مرجع سابق، ص صه ص-7. }
\end{aligned}
$$

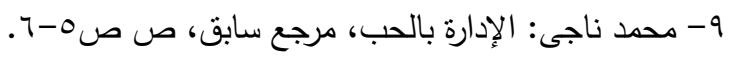

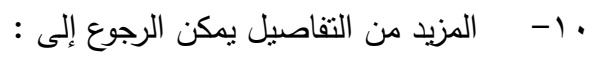

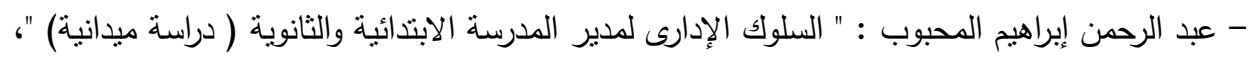

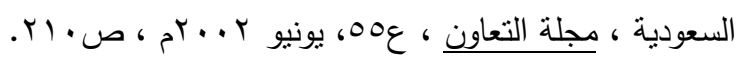

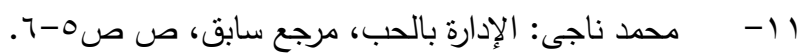

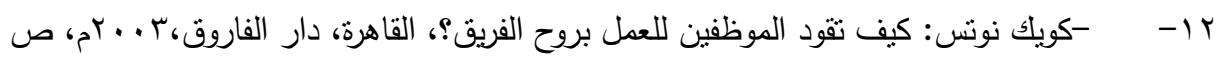

$$
\text { ص }
$$

rا- ريهام إسماعيل زكريا عبد الدايم: تصور مفترح لتمكين مديرى مدارس التعليم العام على صناعة

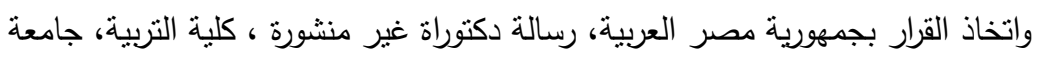

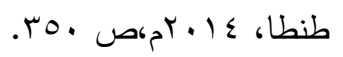

ع ا - نادية محمد عبد المنعم ، عزة جلال مصطفى: الإدارة المدرسية فى ظل المتغيرات العالمية ،

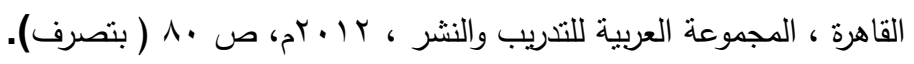

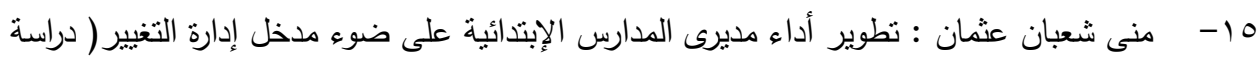
حالة بمحافظة الفيوم ) ، مجلة التربية ، القاهرة ، الجمعية المصرية للتربية المقارنة والإدارة

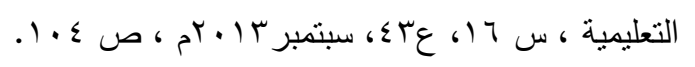

7 ا - خالد عطية يعقوب : نظم اختيار وتدريب مديري المدارس الثانوية الفنية في مصر وماليزيا

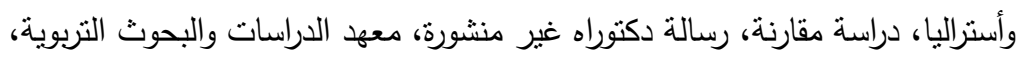

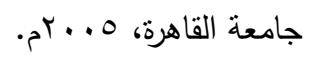


:"الإبداع الإداري في المدارس الثانوية الفنية في مصر وكوريا الجنوبية - دراسة $-1 \mathrm{~V}$

مقارنة "، ملخصات أوراق العمل والبحوث للمؤتمر العلمي السنوي الثاني، مدرسة

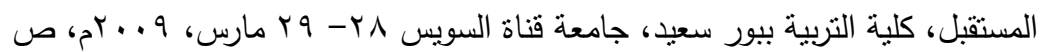

$$
\text { . } 90-9 \leqslant 0
$$

:" دراسة مقارنة للقيادة التيسيرية في المدارس في نيوزلندا وسنغافورة وإمكانية

$-11$

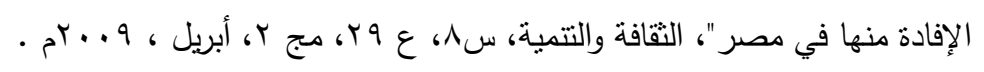

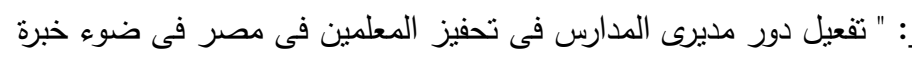

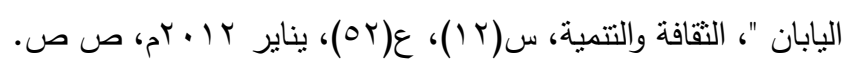

: تطوير نظام مساعلة المعلمين في مصر في ضوء خبرة المملكة المتحدة،

$-r$

رسالة ماجسنير غير منشورة، معهد الدراسات والبحوث التربوية، جامعة القاهرة، ال . بrم.

: نظم اختيار وتدريب مديري المدارس الثانوية الفنية في مصر وماليزيا

وأستراليا، دراسة مقارنة، مرجع سابق.

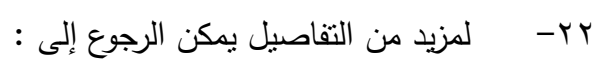

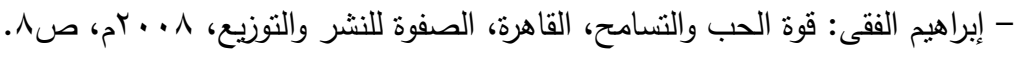

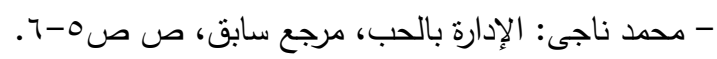

rr- محمد البسيونى السيد القليوبى: المناخ التنظيمى بمدارس التعليم الثانوى الصناعى نظام السنوات الثالاث وعلاقته بالإنتاجية التعليمية ( من وجهة نظر المعلمين والتلاميذ ) دراسة ميدانية

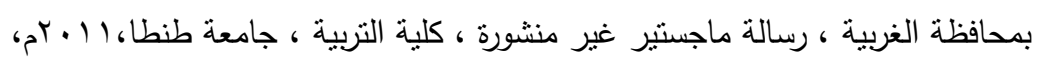

$$
\begin{aligned}
& \text { ص ص }
\end{aligned}
$$

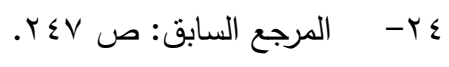

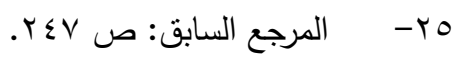

דr- خالا عطية يعقوب :" علاج الوهن الإداري في المدارس في مصر في ضوء خبرات بعض الدول

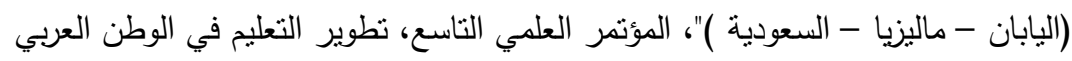

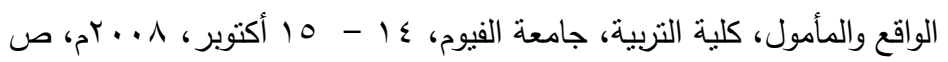

$$
\text { . ص . . 1. }
$$

ف - Tريدة إبراهيم محمود : صنع القرارالتعليمى فى مصر وإنجلترا، دراسة مقارنة، رسالة ماجستير غير

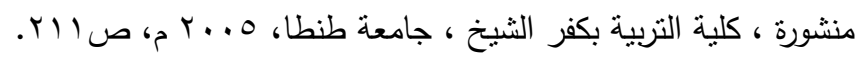

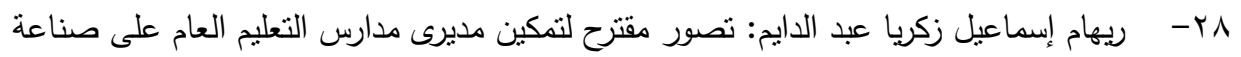

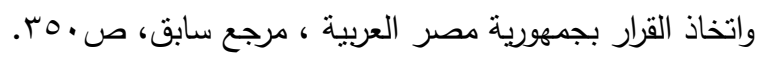

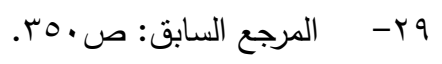




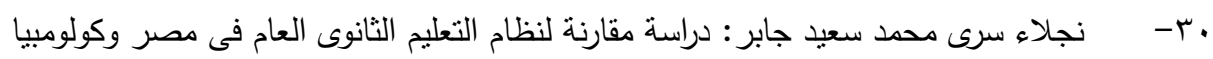

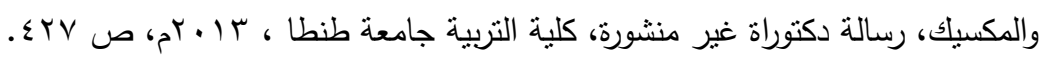

اب- محمد البسيونى السيد القليوبى: المناخ التنظيمى بمدارس التعليم الثانوى الصناعى نظام السنوات الثلاث وعلاقته بالإنتاجية التعليمية ( من وجهة نظر المعلمين والتلاميذ ) دراسة ميدانية

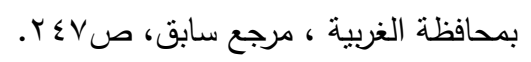

rr- محمود أبو النور عبد الرسول : علاقة المشاركة فى صنع القرار بالأنماط القيادية لمديرى المدارس

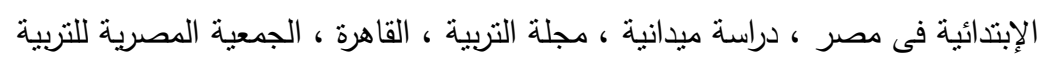

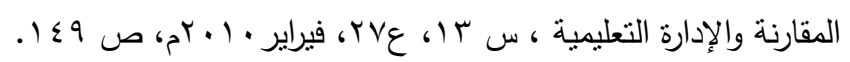

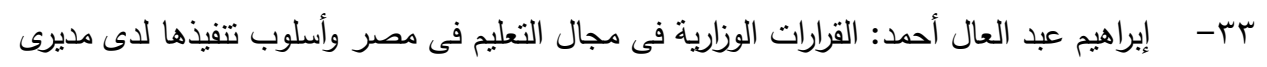

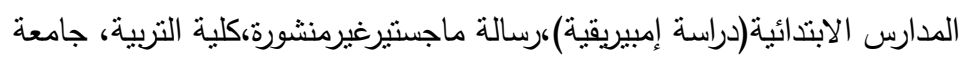

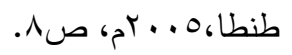

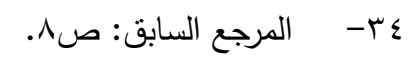

$$
\begin{aligned}
& \text { هץ- المرجع السابق:صی^. }
\end{aligned}
$$

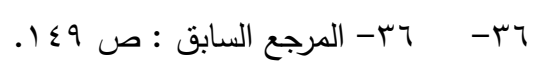

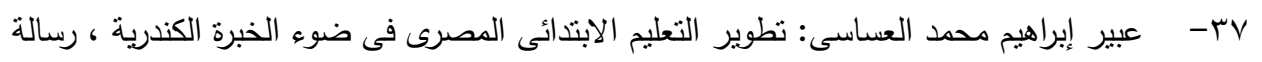

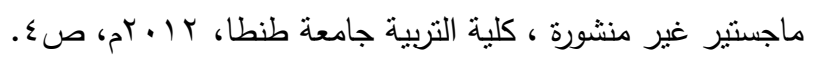

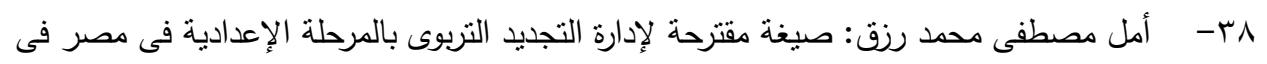
ضوء الاتجاهات العالمية (دراسة مقارنة)، رسالة دكتوراة غير منشورة، كلية التربية، جامعة لإدانة

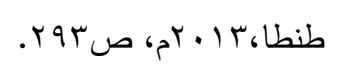

qب- محمد البسيونى السيد القليوبى: المناخ التنظيمى بمدارس التعليم الثانوى الصناعى نظام السنوات الثلاث وعلاقته بالإنتاجية التعليمية ( من وجهة نظر المعلمين والتلاميذ ) دراسة ميدانية

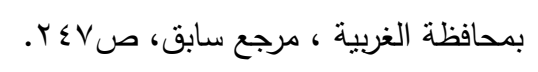

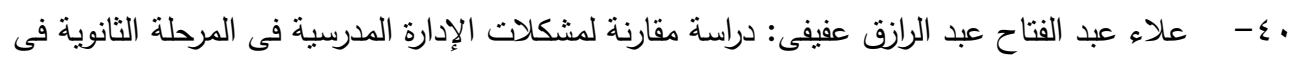

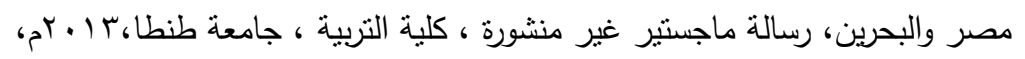

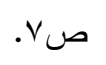

اء - عبير إبراهيم محمد العساسى: نطوير التعليم الابتدائى المصرى فى ضوء الخبرة الكندرية ، رسالة

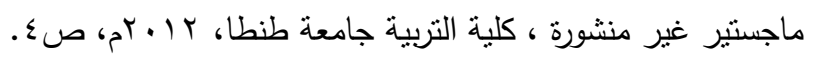

rی- إبراهيم عبد العال أحمد: القرارات الوزارية فى مجال التعليم فى مصر وأسلوب تتفيذها لدى مديرى

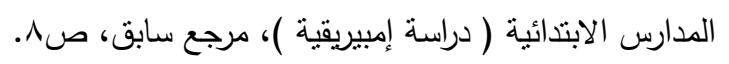

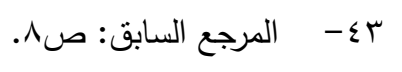


؟ ؟- علاء عبد الفتاح عبد الرازق عفيفى: دراسة مقارنة لمشكلات الإدارة المدرسية فى المرحلة الثانوية فى

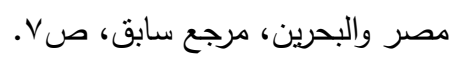

○؟- محسن عبد الستار محمود: تطوير الإدارة المدرسية فى ضوء معايير الجودة الثاملة ، القاهرة،

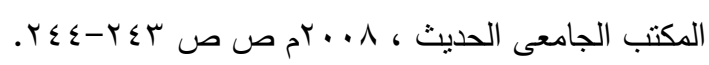

7؟- سهير عبد اللطيف أبو العلا : عملية صنع واتخاذ القرار التربوى فى الإدارة المدرسية ، دراسة

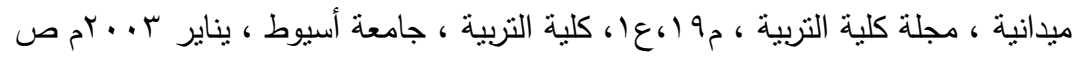

$$
.0 \mathrm{Vr}
$$

乏V

بجمهورية مصر العربية ، مجلة التربية ، القاهرة ، الجمعية المصرية للتربية المقارنة

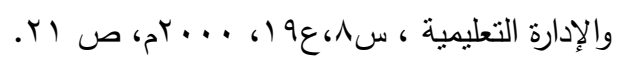

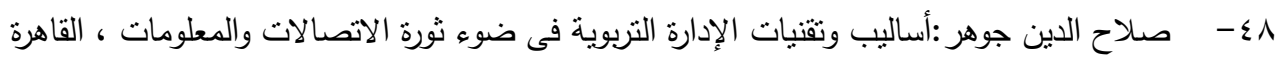

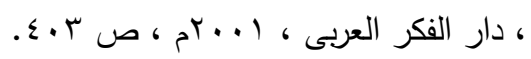

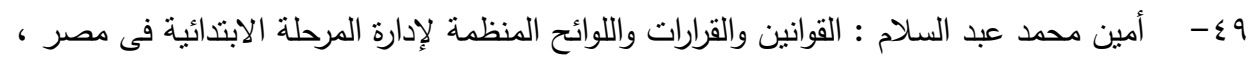

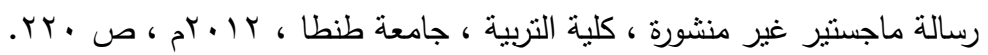

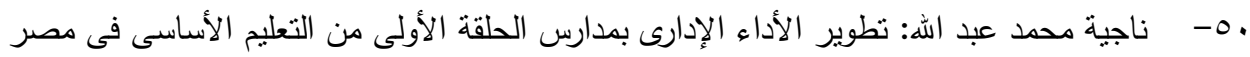

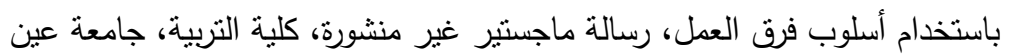

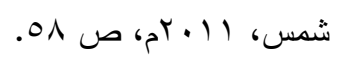

إ- محمد البسيونى السيد القليوبى: المناخ التظظيمى بمدارس التعليم الثانوى الصناعى نظام السنوات الثلاث وعلاقته بالإنتاجية التعليمية ( من وجهة نظر المعلمين والتلاميذ ) دراسة ميدانية

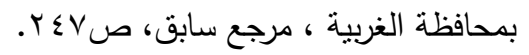

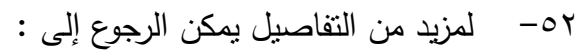

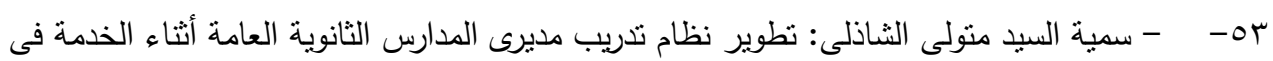

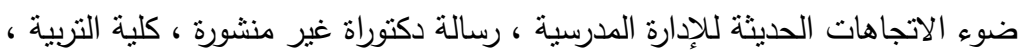

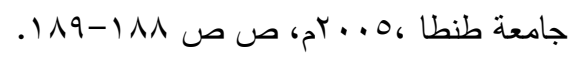

عـ- - خالد عطية يعقوب : نظم اختيار وتدربب مديري المدارس الثانوية الفنية في مصر وماليزيا

$$
\begin{aligned}
& \text { وأستراليا، دراسة مقارنة، مرجع سابق. } \\
& \text { 00- ل لمزيد من التفاصيل يمكن الرجوع إلى : }
\end{aligned}
$$

- Arcaro Jerome : Quality in Education: An Implementation Handbook, Delray -

Beach, Florida: ST. Lucie press. Inc., 1995. 
- عـلاء عبد الفتاح عبد الرازق عفيفى: دراسـة مقارنـة لمشكلات الإدارة المدرسية فى المرحلة الثانويـة فى

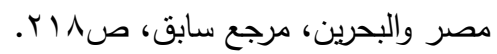

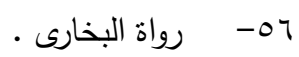

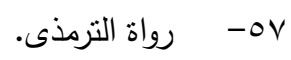

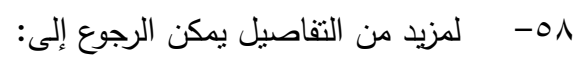

- خالد عطية يعقوب: " تفعيل دور مديرى المدارس فى تحفيز المعلمين فى مصر فى ضوء خبرة اليابان "،

$$
\text { مرجع سابق. }
$$

: " دراسة مقارنة للقيادة التيسيرية في المدارس في نيوزلندا وسنغافورة وإمكانية الإفادة منها

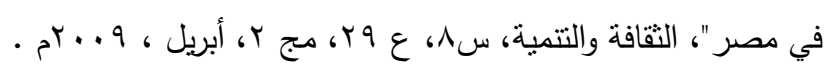

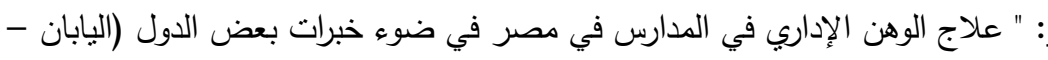

$$
\text { ماليزيا - السعودية )"، مرجع سابق. }
$$

9ه- ديوبولا. ب. فانيان دالين : مناهج البحث في العلوم السلوكية، القاهرة، مكتبة الأنجلو المصرية،

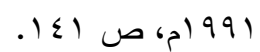

$$
\begin{aligned}
& \text {. }
\end{aligned}
$$

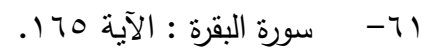

$$
\begin{aligned}
& \text { r r- حديث صحيح : رواة الثيخان. }
\end{aligned}
$$

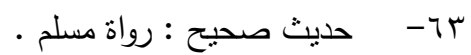

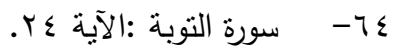

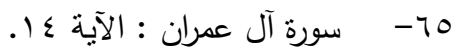

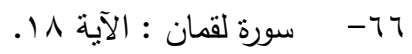

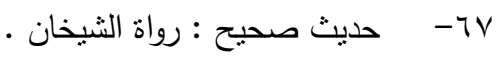

$$
\begin{aligned}
& \text { 1 }
\end{aligned}
$$

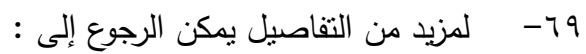

- David osher:"Positive Culture in Urban Schools", Educational Leadership Journal,

V.162, Issue 6 March, 2005, pp.2-8.

• - - محمد جودت ناصر : "قضايا الإدارة ، الإدارة بالحب وإعداد القيادات المحبة" ، القاهرة، مجلة

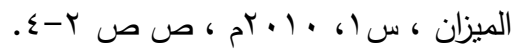

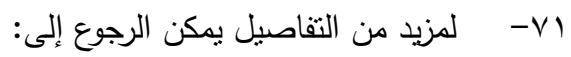

Hand book of positive psychology, Oxford University Press, 2005.: -Snyder C. , Lopez J.

-Hanberg Lisa:"Love and Management", all Business.Com., feb.2010,pp.2-22. 
: - إمزيد من التفاصيل يمكن الرجوع إلى

- Blumberg Arthur, Greenfield William: The Effective Principal, Boston: Allyn and Bacon, Inc. 1998.

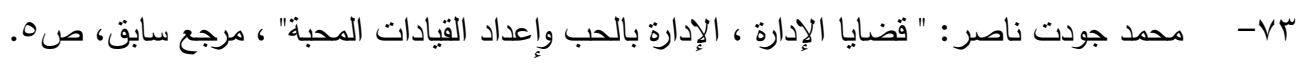

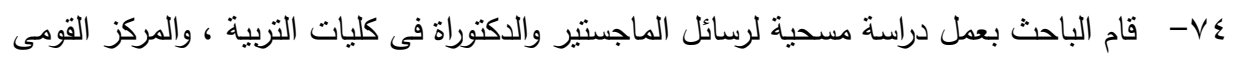

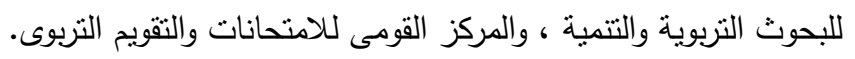

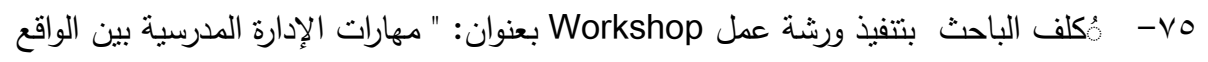

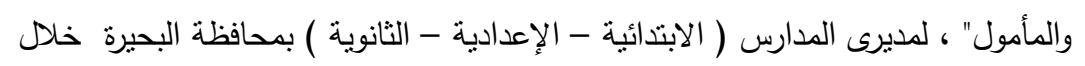

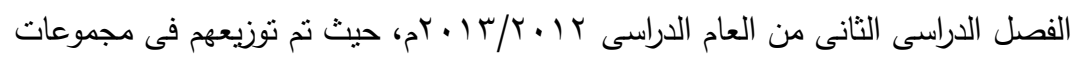

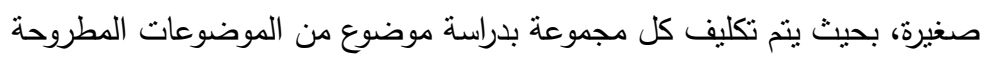

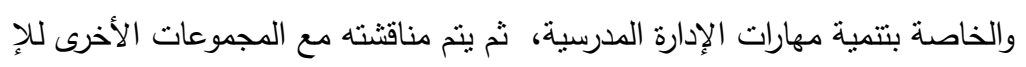

ستفادة من كافة الآراء والمقترحات ، ومن ثم الخروج ببعض المقترحات العملية.

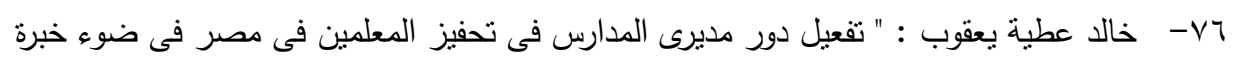

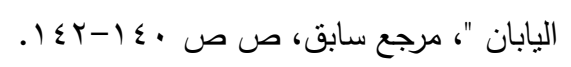

-VV

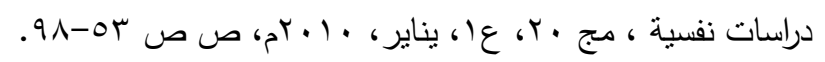

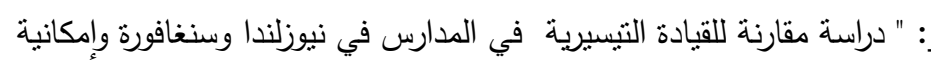
$-\vee \wedge$

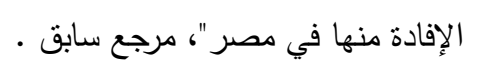

( $-\vee 9$

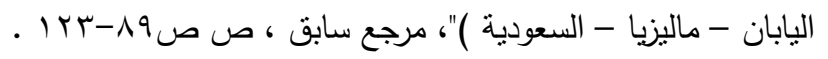

$$
\begin{aligned}
& \text {. - لمزيد من التفاصيل يمكن الرجوع إلى: }
\end{aligned}
$$

- Kastler Ann Elizabeth: Teachers Perception of Their Involvement in Decisionmaking and organizational climate as these relate to the degree of schoolpased Management in selected Minnesota public elementary Schools, Ph.D., 1993.

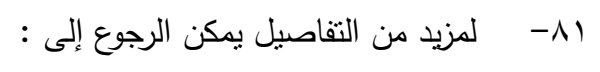

- مصطفى خليل الثرقاوى:مدخل إلى علم النفس الاجتماعى، بطى، القاهرة ن دار الفكر العربى ،

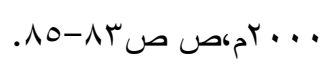

- محمد السيد عبد الرحمن:علم النفس الاجتماعى المعاصر ، مدخل معرفى ،القاهرة ، دار الفكر العربى

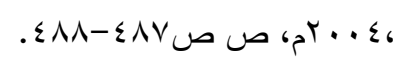


-Hand book of positive psychology,Oxford University Press,2005.: -Snyder C., Lopez J.

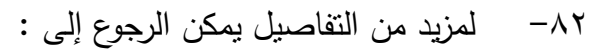

--Brown Paul:Management by love , Amazon,Com.,January, 2010, pp.2-8.

- مدحت محمد أبو النصر : الإدارة بالحب والمرح ، القاهرة ، مجموعة النيل العربية ، 11 + كبم ، ص

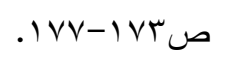

rی- هانى عبد الرحمن الطويل : الإدارة التعليمية ، مفاهيم وآفاق ، الأردن ، عمان ، دار وائل للطباعة

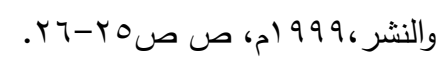

ع - محمد جودت ناصر : " قضايا الإدارة بالحب ، الإدارة بالحب وإعداد القيادات المحبة "، القاهرة ،

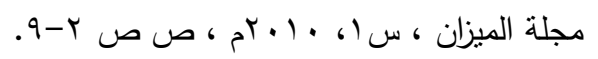

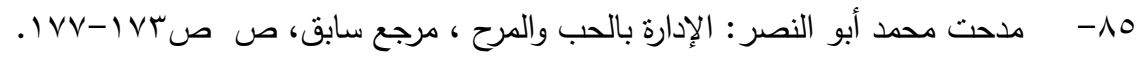

$$
\text { \ }
$$

- Kastler Ann Elizabeth: Teachers Perception of Their Involvement in Decisionmaking and organizational climate as these relate to the degree of school-pased Management in selected Minnesota public elementary Schools, Ph.D., 1993.

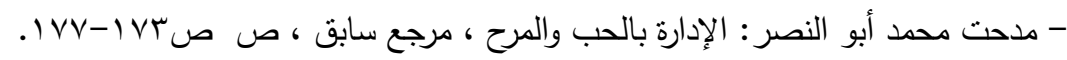

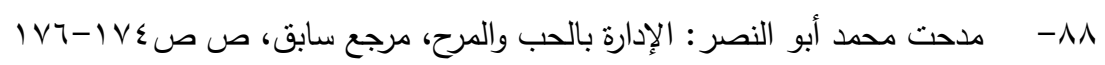

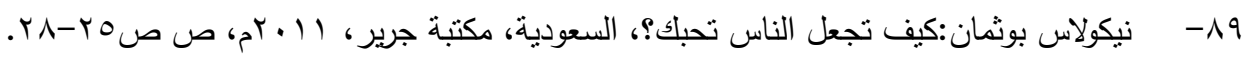

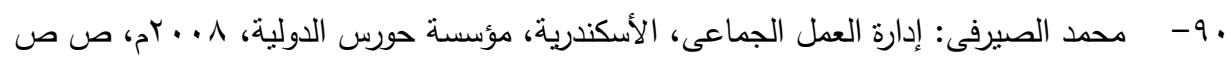

$$
\begin{aligned}
& \text {. rVE-rVT } \\
& \text { 19- ل لمزيد من التفاصيل بمكن الرجوع إلى : }
\end{aligned}
$$

- خالد عطية يعقوب : إدارة الموارد البشرية، وزارة التعليم العالى، المعهد العالى للدراسات النوعية بالجيزة،

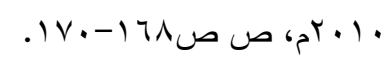

- عبد القادر حسن : "كيف تملك حب موظفيك للعمل" ، مجلة العداقى لبحوث التسويق ، المملكة العربية

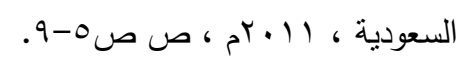

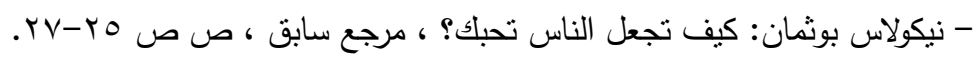

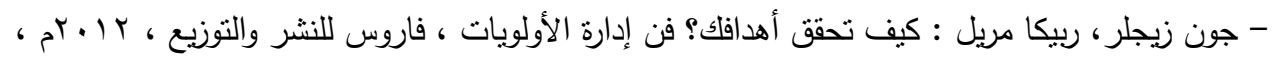

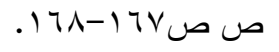

$$
\begin{aligned}
& \text { r- رواة البخارى : حيدث صحيح. }
\end{aligned}
$$




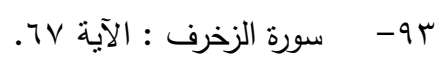

ع - فتحى درويش عشيبة، مصطفى أحمد أمين: الإدارة المدرسية والصفية ، كلية التربية ، جامعة

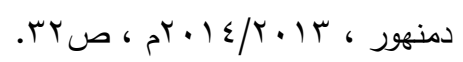

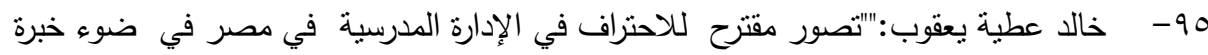

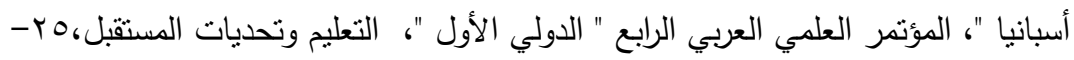

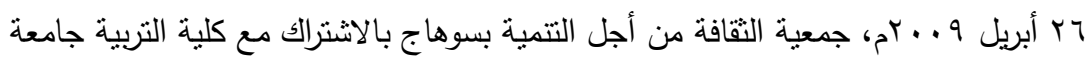

$$
\text { سوهاج }
$$

49- كيث ديفيز : السلوك الإنسانى فى العمل ، دراسة العلاقات الإنسانية والسلوك التتظيمى ، ترجمة /

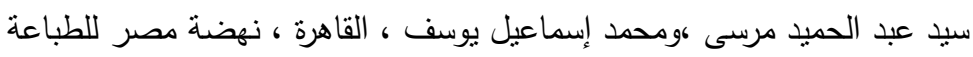

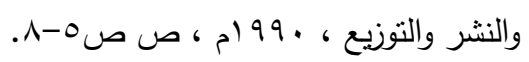

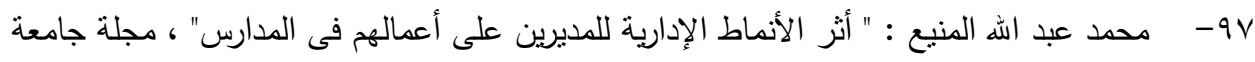

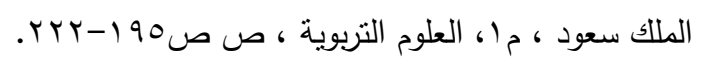

19 - محمد البسيونى السيد القليوبى: المناخ التنظيمى بمدارس التعليم الثانوى الصناعى نظام السنوات الثلاث وعلاقته بالإنتاجية التعليمية ( من وجهة نظر المعلمين والتلاميذ ) دراسة ميدانية

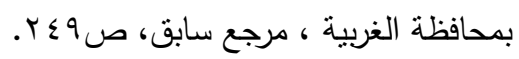

$$
\begin{aligned}
& \text { 99- سورة القلم : الآية ع. }
\end{aligned}
$$

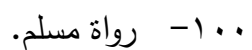

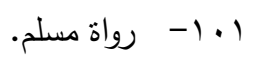

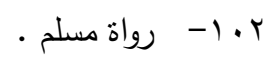

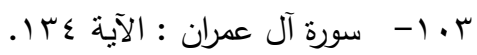

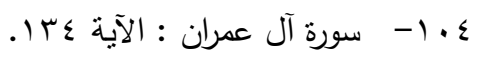

$$
\begin{aligned}
& \text { ه. 1- سورة آل عمران : الآية عسا. }
\end{aligned}
$$

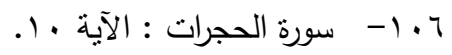

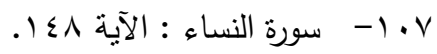

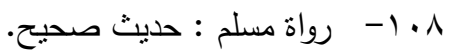

$$
\begin{aligned}
& \text { 9.1. - رواة مسلم : حديث صحيح. }
\end{aligned}
$$

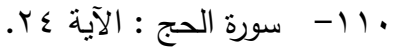

$$
\begin{aligned}
& \text { 111- سورة فصلت : الآية . r. }
\end{aligned}
$$

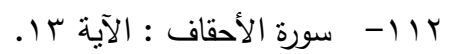

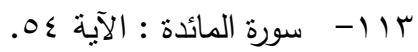

$$
\begin{aligned}
& \text { ع 11- سورة الحجرات : الآية . 1. } \\
& \text { 110- سورة الحجر : الآية Vع. : الاية . }
\end{aligned}
$$




$$
\begin{aligned}
& \text { 111- سورة الثعراء : الآية 199. }
\end{aligned}
$$

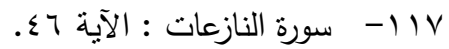

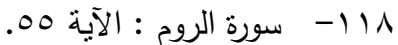

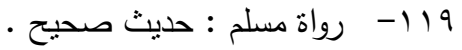

$$
\begin{aligned}
& \text { • Yו- سورة السجدة : الآية عץ. }
\end{aligned}
$$

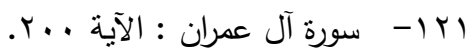

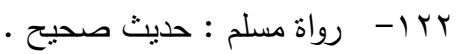

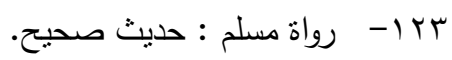

$$
\begin{aligned}
& \text { ع با - رواة مسلم : حديث صحيح. }
\end{aligned}
$$

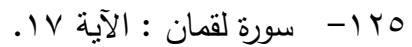

$$
\begin{aligned}
& \text { TYו - رواة مسلم : حديث صحيح. }
\end{aligned}
$$

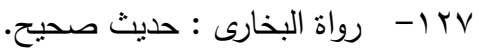

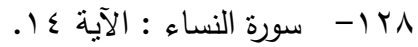

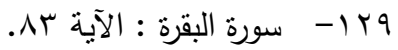

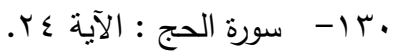

$$
\begin{aligned}
& \text { ابا- سورة المؤمنون : الآية ب. الاية } \\
& \text { r آו - رواة مسلم: حديث صحيح. }
\end{aligned}
$$

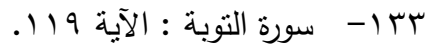

$$
\begin{aligned}
& \text { ع זו- رواة مسلم: حديث صحيح } \\
& \text { هبا- - سورة القصص : الآية } \\
& \text { דبر- سورة لقمان : الآية ؟ب. }
\end{aligned}
$$

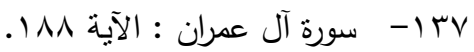

$$
\begin{aligned}
& \text { مץا- سورة الأحزاب : الآية إع. الآية }
\end{aligned}
$$

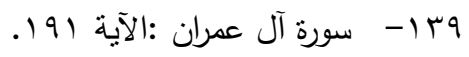

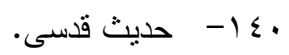

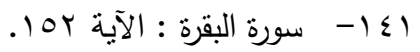

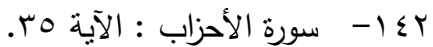

$$
\begin{aligned}
& \text { ع ع إ- رواة مسلم }
\end{aligned}
$$

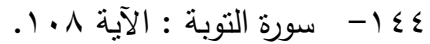

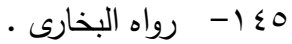

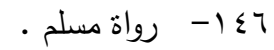

